\title{
Hacia una interpretación más eficaz del texto audiovisual
}

\author{
Una visión teórico-práctica
}

\author{
del armado de subtítulos
}

"El cine siempre fue considerado un arte universal, debido al presupuesto (un poco equivocado) de que el lenguaje de las imágenes es universalmente entendido, pero esa supuesta universalidad desaparece cuando los personajes comienzan a hablar. De repente, a mediados de los años veinte, descubrimos que si el cine era hablado, tendría necesariamente que enfrentar la diversidad lingüística del planeta." Arlindo Machado 


\section{$\underline{\text { ÍNDICE }}$}

Breve fundamentación del tema $\ldots \ldots \ldots \ldots \ldots \ldots \ldots \ldots \ldots \ldots \ldots \ldots \ldots$ pág. 3

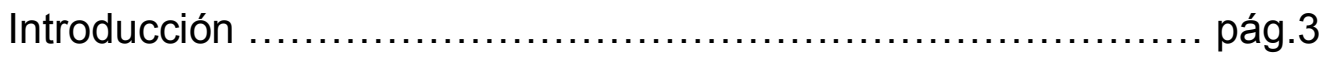

La necesidad constante de expresar e interpretar significado ..... pág.8

i.i. ¿Por qué la multimodalidad? ........................... pág. 12

i.ii Un párrafo aparte para la intermedialidad ................ pág.16

i.iii El subtítulo, una imagen entre tantas .................... pág. 25

i.iv Una relación con algunas rispideces ....................... pág.32

Subtitulado convencional ......................................... pág.35

ii.i Una descripción más detallada ......................... pág.35

ii.ii Problemáticas particulares de géneros determinados .. pág.55

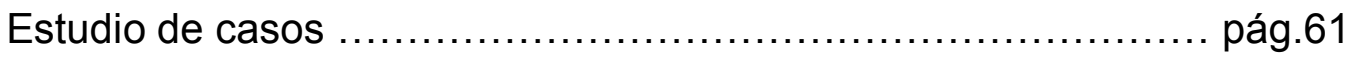

iii.a Cuando la imagen plantea un obstáculo ................ pág.62

iii.b Cuando la imagen tiende un puente ..................... pág.71

iii.c Cuando la imagen es la única fuente de información ... pág.74

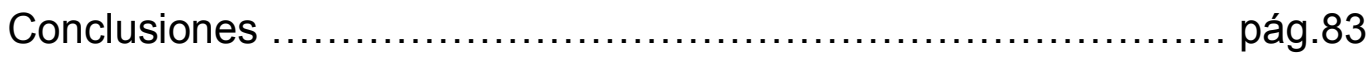

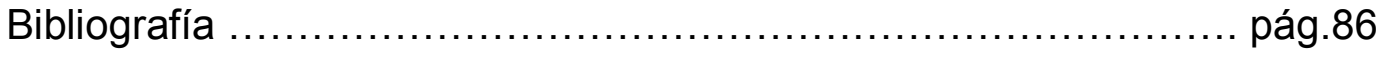




\section{BREVE FUNDAMENTACIÓN DEL TEMA}

En mi experiencia como profesora de materias relacionadas con la traducción audiovisual, noto que uno de los aspectos que más preocupa a los alumnos es la supuesta pérdida de información cuando traducen material en formato de subtítulos. Con frecuencia, los actores enuncian sus parlamentos a una velocidad superior, o muy superior, al ritmo de lectura del espectador promedio, lo que pone al traductor de subtítulos en la obligación de decidir cuál información incluir y cuál suprimir. Y en su cándido afán por alcanzar la fidelidad palabra por palabra con el texto original, los alumnos se resisten a efectuar cualquier tipo de recorte.

Los traductores con cierto recorrido dentro del campo de la traducción audiovisual, especialmente los que se dedican a la confección de subtítulos, hacen una selección aparentemente intuitiva de la información. Sin embargo, existe un proceso previo, casi siempre inconsciente, mediante el cual la mente descarta algunos elementos y conserva otros.

Por ello, el desafío que me propongo como traductora y docente es transitar minuciosamente ese recorrido con una perspectiva analítica, con el fin de desglosar sus tramos, detenerme en ellos, interpelarlos y transformar ese proceso en una herramienta metodológica que brinde a los alumnos, futuros traductores, en el caso de verse enfrentados a la necesidad de modificar los parlamentos originales, un procedimiento de trabajo ordenado que responda a criterios teóricos. En síntesis, reformular el conocimiento empírico y convertirlo en un recurso que facilite la tarea y optimice los resultados.

\section{INTRODUCCIÓN}

La comunicación mediante la combinación de imágenes y texto es una práctica cada vez más extendida en el mundo actual; solemos asociar el material audiovisual únicamente al entretenimiento o a la información, pero también está 
presente en nuestras vidas cuando, por ejemplo, utilizamos un cajero automático, compramos un pasaje de avión, seguimos las instrucciones que nos dicta un video de YouTube o capacitamos a un grupo de obreros sobre el uso de una máquina, herramienta o procedimiento corporativo nuevos. Esta tendencia amplía el mercado de la comunicación audiovisual y debería exigir una mayor profesionalización de los agentes transmisores de la información. De allí surge la necesidad de comenzar a delinear un marco teórico que oriente la metodología de la enseñanza de, en este caso, la traducción de subtítulos, con el fin de optimizar el traspaso de contenidos cuando coexisten dos canales visuales en simultáneo: el texto escrito y la imagen.

En un artículo de su autoría, Arlindo Machado, quien define al traductor de subtítulos como un "profesional"1 que además de tener que lidiar con restricciones temporales, tecnológicas y de formato, compensar o resolver de algún modo las diferencias entre la cultura de origen y la de llegada, tomar decisiones con respecto al uso de jergas, términos con un marcado color local y palabras soeces, y que debe en ocasiones prácticamente inventar un texto nuevo que, según se pretende, el espectador necesitará leer confortablemente, ese mismo Arlindo Machado afirma que "Hay grandes traducciones en el campo de la literatura, pero nadie puede esperar que el cine contrate a Octavio Paz o a José Saramago para subtitular una película" ${ }^{2}$. Si se considera la traducción audiovisual como una rama de la traducción literaria (como lo demuestra la variada oferta en capacitación de posgrado en las que confluyen ambas disciplinas), esta reflexión no solo no sería válida, sino que también resultaría injusta ${ }^{3}$. La traducción audiovisual no corresponde a una categoría "menos profesional" o inferior. Sin embargo, es imposible pensar la formación profesional y académica sin un anclaje teórico. Ese es el aporte que pretende dar este trabajo.

\footnotetext{
1 Machado, Arlindo (2009), página 113.

2 Machado, Arlindo (2009), página 115.

3 Mijaíl Bajtín toma como referencia los debates socráticos cuando define al diálogo como género discursivo-literario. Y es en los medios de comunicación audiovisual (en el cine, pero principalmente en la televisión) donde se observa una preponderancia casi absoluta de las distintas variantes del discurso oral, entre ellas, el diálogo. Tras la imposición del texto escrito a partir de la creación de la imprenta, la radio, el cine y la televisión recuperaron y revalorizaron las características de la oralidad. (Machado, Arlindo, 2000)
} 
En Argentina, la bibliografía acerca de la modalidad a la que se circunscribe este análisis, la traducción de subtítulos, es escasa, aunque es cierto que, en los últimos años, se acrecentó notablemente la publicación de artículos académicos sobre el tema; por otro lado, la bibliografía dedicada a la enseñanza de la traducción audiovisual en general es más escasa aun, en este país y en el resto del mundo. En las últimas dos décadas, especialmente en España ${ }^{4}$, ha habido un aumento en la oferta de instancias de capacitación de posgrado en el campo de la traducción audiovisual; y la tendencia va en aumento. En nuestro país, unas pocas universidades cuentan con materias relacionadas $\mathrm{o}$ incluyen la traducción audiovisual en el programa de otras asignaturas ${ }^{5}$, y existe un solo postítulo, la Diplomatura Superior en Traducción de Textos Audiovisuales, de creación reciente (mayo de 2014). Las posibilidades de aprendizaje se concentran en cursos y talleres, dictados por particulares y ajenos al ámbito académico.

La tendencia creciente a brindar y recibir información a través de medios audiovisuales, y la exigencia de hacerlo de manera precisa y veraz, impone la formación de profesionales idóneos en esta rama de la traducción; sin embargo, la preocupación de las instituciones por suplir esta carencia no tiene en cuenta, al menos en lo que concierne a los países de habla castellana, ninguna clase de reflexión metodológica, y las instancias de capacitación siguen, hasta el momento, basándose en la práctica y en la mera transmisión anecdótica de experiencias profesionales. Tomando los conceptos de John Swales ${ }^{6}$, bien podría decirse que existe un nicho vacío en la didáctica de la traducción audiovisual en general y en la de la traducción de subtítulos en particular, lo que crea un espacio de investigación vacante que debe ser ocupado. Este trabajo propone comenzar a habitar ese nicho con una reflexión sobre la problemática de la traducción de subtítulos y cuál es su relación con la imagen, y ofrecer un esbozo para la

\footnotetext{
4 La Universidad Autónoma de Barcelona fue pionera con el lanzamiento de una maestría en 2001 .

5 La Universidad del Museo Social Argentino incluye en el último año del plan de estudios del Traductorado Público en Inglés la materia Traducción Audiovisual. Asimismo, el nuevo plan para el Traductorado de Inglés del Instituto de Enseñanza Superior en Lenguas Vivas "Juan Ramón Fernández" (que empezó a implementarse en 2014) cuenta con esta materia en el trayecto de especialización en Traducción Literaria. Ambas instituciones educativas se encuentran en el ámbito de la ciudad de Buenos Aires.

6 Genre Analysis (1990), página 159.
} 
construcción de un marco teórico que permita mejorar el aprendizaje y la tarea del traductor dedicado a esta especialidad.

En la búsqueda de una corriente de pensamiento en la cual encuadrar mi análisis, me dediqué a explorar una variedad de artículos académicos en los que se postulaban enfoques teóricos que, en mayor o menor medida, estudiaban la relación entre la imagen en pantalla y el texto escrito, como así también los distintos modos de significación presentes en los textos audiovisuales. Dada la variedad de canales de expresión presentes en el material audiovisual narrativo, se requería un enfoque teórico que estudiara el significado en todas sus manifestaciones sociales y culturales, y que permitiera el análisis de los aportes y de las limitaciones de los elementos no-textuales, y su posible contribución o efecto en el armado de subtítulos. De todos estos enfoques, el multimodal (Kress y van Leeuwen, 2001) ${ }^{7}$ es el que, creo, resulta de mayor utilidad para reflexionar sobre los mecanismos semióticos que intervienen en la traducción cuando coexisten el canal del habla y el de las imágenes. A su vez, el enfoque multimodal se encuadra dentro de la semiótica social, la que no solo contempla al emisor y al receptor de un acto comunicativo, sino que también incorpora el estado de situación (el "contexto", como lo define Jakobson) en el que se produce el acto, un aspecto fundamental en cualquier operación traductora. Mientras que la semiótica estudia los signos como instrumentos necesarios para cualquier tipo de comunicación en cualquier entorno social, la semiótica social se concentra en la reelaboración que los individuos hacen de los significados de esos signos de acuerdo con el contexto en que se produzcan. La semiótica social se emparenta con el enfoque multimodal cuando se analiza la participación de los diferentes modos de significar en el evento semiótico. Como argumenta Eliseo Verón en su libro "La semiosis social", en el campo de los procedimientos discursivos, toda producción de sentido es social y todo fenómeno social constituye un proceso de producción de sentido ${ }^{8}$. Por otro lado, sin embargo, e independientemente de que

\footnotetext{
7 Opté por utilizar el concepto de Gunther Kress y Theo van Leeuwen (multimodality), quienes hacen referencia a los distintos "modos" de expresión: la escritura, la imagen, los colores, el diseño, y por supuesto, la expresión gráfica.

8 Verón, Eliseo (1993) página 125
} 
la interpretación se desarrolle dentro de un esquema social establecido, no se debe soslayar la injerencia que las subjetividades de cada individuo tiene en la interpretación de los signos. Por lo tanto, ningún evento semiótico debería analizarse como un hecho exclusivamente individual o exclusivamente social. Cualquier texto, de cualquier índole, admite múltiples lecturas, pero no orienta por sí mismo hacia una en particular; sin el rol del individuo, el texto dejaría de ser un "objeto significante" (Verón) y se cancelaría la relación entre su generación y su efecto. La lectura que el traductor haga de los signos emitidos no escapa a esta visión particular y sesgada, limitada por los constructos sociales. Tomar conciencia de esta realidad hará que el traductor concentre su atención en evitar subjetividades innecesarias en el traslado de información, ya que su participación constituye un peldaño intermedio en esta cadena hermenéutica que finaliza en el receptor/espectador ${ }^{9}$.

La primera parte del trabajo menciona aspectos que influyen en el proceso de generación y transmisión de significado y explica la relación entre la multimodalidad y el correcto aprovechamiento del contenido semiótico de los canales visuales para la traducción de subtítulos. Se estudia también la injerencia que otros conceptos, como el de intermedialidad, pueden tener en la elaboración de subtítulos y la problemática relacionada con determinados géneros audiovisuales, como la emisión de testimonios en vivo. Se realiza un análisis extenso del subtítulo como imagen en dos secciones por separado y, en el último tramo, se incluye el desglose de casos concretos, teniendo en cuenta los conceptos vertidos anteriormente.

Con referencia al corpus que en parte motivó este trabajo y que revisaré, como acabo de indicar, en el último tramo, es pertinente señalar que el material elegido se restringe a películas, series y dibujos animados, ya que es en los textos audiovisuales narrativos o de ficción donde, por un lado, el eje está puesto en la trama y, por el otro, el uso del lenguaje es más creativo (lo que, a su vez, habilita el uso creativo del lenguaje por parte del traductor); además, es en estos géneros

\footnotetext{
${ }^{9}$ Más adelante, se ahondará en el enfoque multimodal y su relación con el armado de subtítulos.
} 
donde se distinguen con mayor claridad las distintas funciones y metas del lenguaje. Por otra parte, cabe resaltar que, por su objetivo social y su contenido, existe una clara preponderancia cuantitativa en la producción y en la aceptación del público de esta clase de material audiovisual por sobre el material no narrativo (documentales, noticieros, videos informativos, etcétera). El material audiovisual mencionado se podrá visualizar a través de capturas de pantalla en el trabajo.

\section{LA NECESIDAD CONSTANTE DE EXPRESAR E INTERPRETAR SIGNIFICADO}

Jaan Valsiner ${ }^{10}$ afirma que, a pesar de las diferencias culturales que existen entre los pueblos y las personas, el proceso de creación de significado es universal y que la mayor parte del significado afectivo elaborado por el hombre es de carácter no verbal.

Mal que les pese a los defensores de la traducción automática e informatizada, la tarea de cualquier traductor es transmitir conceptos (no únicamente términos) en un código lingüístico distinto del original. En el caso del traductor de subtítulos - a diferencia de sus pares dedicados a otros ámbitos de la traducción, como la literaria, la técnico-científica o la jurídica-, la tarea se complejiza por la necesidad de lidiar con limitaciones técnicas y con una variedad de canales de expresión, tanto verbales como no verbales. Mona Baker, en Routledge Encyclopedia of Translation Studies, define el material audiovisual como una composición semiótica formada por cuatro canales: el auditivo verbal (Ios parlamentos o diálogos), el auditivo no-verbal (los ruidos, los sonidos, la música), el visual verbal (los subtítulos o los carteles que puedan aparecer en pantalla) y el visual no-verbal (las imágenes estáticas o en movimiento) ${ }^{11}$. Aunque comúnmente se crea que el canal verbal, tanto auditivo como visual, es el más potente y eficaz en la transmisión de significados, cuando se trata de material

Valsiner, Jaan (2008)

11 Bogucki, Eukasz (2004), página 82 
audiovisual, no sería correcto desconocer la carga semántica de los elementos noverbales, la que, en ocasiones, supera la claridad del lenguaje verbal.

La información que aportan los distintos canales puede ser tanto complementaria como redundante, crucial como irrelevante. En la mayoría de los casos (excepto cuando el material contiene poco diálogo o este se expresa en forma pausada), el traductor es quien decide qué datos conserva y qué datos recorta o descarta. El desafío reside en llevar a cabo una selección objetiva y eficiente.

A pesar de sus diferencias teóricas, Charles Peirce y Ferdinand de Saussure coinciden en que la interpretación de esa fusión de forma y contenido llamada signo siempre está marcada por cierta subjetividad. Para Peirce, la subjetividad la aporta el receptor, quien le otorga al signo un significado impulsado por sus propios intereses (la motivación, de acuerdo con la terminología del autor) y lo transforma en un signo nuevo (o el interpretante), susceptible de ser interpretado de otra manera por otro receptor, y así infinitamente. Estas tres entidades semióticas (signo, significado e interpretante) pueden ser concretas o abstractas, lo que marca una diferencia con el concepto de Saussure, e incluyen los signos auditivos no-verbales y visuales no-verbales. En la concepción de Pierce, la emisión intencional de un signo no implica que necesariamente se le otorgue a ese signo el significado pretendido por el emisor. En ocasiones, los gestos faciales o de cualquier otra parte del cuerpo, o también los tonos y las inflexiones de la voz, conllevan una carga connotativa que alcanza al receptor, independientemente de la voluntad del emisor. En el plano audiovisual, esa discrepancia se observa claramente en materiales provenientes de países de culturas orientales, en las que la gestualidad y el tono de voz expresan significados distintos que en Occidente.

Para Saussure, en cambio, el signo es la combinación de un objeto o manifestación tangible que tiene lugar en el mundo exterior (el significante) y la representación mental que el individuo se hace de ese objeto o manifestación (el significado); el otorgamiento de significado al significante se rige tanto por las 
convenciones sociales como por la arbitrariedad individual, lo que demuestra el poder que lo social ejerce sobre cualquier interpretación. Saussure hace hincapié en que el significado otorgado a un significante está estrictamente relacionado con la actividad mental y psicológica del receptor. De todas maneras, los ejemplos estudiados por él comparten la característica de pertenecer a sistemas artificiales y convencionalizados, lo que reduce las posibilidades de interpretación por parte del receptor. "[...] los partidarios de una semiología saussureana distinguen [...] entre los signos intencionales y artificiales (entendidos como 'signos' en sentido propio) y todas aquellas manifestaciones naturales y no intencionales a las que, en rigor, no atribuyen el nombre de 'signos'.."12 La convencionalidad de los signos icónicos, no obstante, también se determina por su aceptación o difusión dentro de un marco temporal y de una sociedad. En su libro, "La definición del arte", Umberto Eco narra una anécdota —que, a su vez, extrajo de un libro de Gombrich $^{13}$ - que sirve como ejemplo de lo anterior. Gombrich describe la recepción apática y crítica que tuvieron las obras del pintor John Constable cuando experimentó con una técnica nueva para representar con realismo la presencia de luz en el paisaje. Constable había creado un código distinto para transmitir en la tela los efectos de la luz; y solo una vez que el público receptor logró comprender, asimilar y adecuarse al nuevo sistema de codificación, la obra de Constable pudo interpretarse como realista. Del mismo modo, ciertas manifestaciones sociales, como la costumbre de eructar después de una comida, se interpretan de maneras opuestas de acuerdo con la sociedad en la que tengan lugar $^{14}$.

El traductor, receptor e intérprete por la naturaleza de su oficio, no resulta inmune ante la subjetividad individual ni a las convenciones sociales $y$, por lo tanto, se impone en su tarea la necesidad de descartar cualquier proceso intuitivo de selección y ceder espacio a un análisis reflexivo sobre los componentes del

\footnotetext{
2 Eco, Umberto (2000). Página 32.

13 Gombrich, Ernest. Art and Illusion, Bollingen series, Nueva York, 1961.

14 El artículo "Malentendidos culturales", del 3 de junio de 2015, del diario digital La Vanguardia, de España, enumera varios ejemplos sobre esta relación entre iconicidad y significado (http://www.lavanguardia.com/estilos-de-vida/20120802/54331576695/malentendidosculturales.html).
} 
signo audiovisual y la consecuente jerarquización de los mismos. En el caso específico del traductor que elabora subtítulos, la posibilidad de una lectura subjetiva del material se acrecienta cuando se trabaja con textos audiovisuales de función emotiva o poética (Jakobson) o con textos audiovisuales estéticos (Eco), ya que "el emisor de un texto estético, en la medida en que aspira a estimular un complejo trabajo interpretativo en el destinatario, enfoca su atención en sus posibles reacciones, de modo que dicho texto representa un retículo de actos comunicativos, encaminados a provocar respuestas originales" ${ }^{\prime 15}$. Las variantes interpretativas aumentan cuanto mayor sea el desvío de las normas instituidas, o de la relación entre expresión y contenido. Pero esta apertura del abanico hermenéutico, en vez de simplificar el análisis, haciendo que el peso recaiga exclusivamente en la toma de posición del receptor, lo complejiza, ya que invita a reconsiderar los códigos en los que se basa la emisión y a proponer nuevas visiones de los mismos. En este proceso tan marcado por la ambigüedad, el traductor, como primer receptor de la obra original antes de llegar al espectador, puede no respetar las intenciones originales del emisor, sin que esto implique una traición ni una comprensión errónea del texto de partida. Su interpretación, la del traductor, tampoco anula la posibilidad de que el espectador vuelva también a interpelar los códigos propuestos por el traductor y reelabore el significado. No existe el receptor definitivamente final, y las relecturas pueden ser tantas como receptores existan, tal como propone Peirce.

Estas consideraciones se ajustan cómodamente a la interpretación de un lenguaje como el audiovisual, con su profusión de signos, tanto verbales como no verbales. El cine y sus derivados en el terreno de las manifestaciones audiovisuales se han transformado en un poderoso canal de expresión y, como consecuencia, han ido generando, a lo largo del tiempo y de su desarrollo, una semiótica propia. La manipulación de los elementos fílmicos por parte del emisor y la consiguiente reelaboración de estos elementos por parte de los receptores transforman "en un discurso lo que podría haber sido únicamente un calco visual

15 Eco, Umberto (2000). Página 367. Las itálicas pertenecen al original. 
de la realidad"16; y, por lo tanto, la pretensión de la semiótica cinematográfica es, al igual de lo que ocurre en cualquier otra lengua, ajustar sus componentes a una serie de disposiciones regladas ${ }^{17}$.

Es esta semiótica la que el traductor debe aprender a desentrañar. Por eso, el eje de este trabajo es plantear un marco de reflexión teórica que contribuya a la funcionalidad de la traducción de subtítulos; en otras palabras, contribuir a que el traductor logre transmitir los conceptos del material original con corrección, pero, primordialmente, con eficacia. Volviendo a la terminología de Peirce, en la traducción de subtítulos, el interpretante deberá satisfacer el fin último que es comunicar significado de la manera más clara y concisa posible.

Las dos próximas entradas se dedicarán al análisis de los conceptos de multimodalidad e intermedialidad. Más adelante, se incluirán otros enfoques teóricos, relacionados con el propósito de este trabajo.

\section{1. ¿POR QUÉ LA MULTIMODALIDAD?}

En la actualidad, la multimodalidad es un elemento siempre presente en cualquier forma de comunicación humana que pretenda ser ágil y eficaz. Nadie concibe la elaboración de material informativo, e incluso educativo —carteles en la vía pública o dentro de edificios o establecimientos, afiches publicitarios, folletos explicativos, páginas web, pantallas de máquinas de servicios (cajeros automáticos, estaciones para la compra de pasajes o para la iniciación de trámites por Internet) - , con la utilización exclusiva de texto escrito. En estos intentos comunicativos multimodales, lo textual interactúa con lo sonoro y con lo gráfico, ya se trate de imágenes, símbolos, combinación de colores o de formatos, 0 melodías, sonidos y ruidos diversos.

Los textos audiovisuales son una arista más de la comunicación humana. Como mencioné anteriormente, en el campo audiovisual convergen, como mínimo,

16 Metz, Christian (1964-1968), página 129.
17 Metz, Christian (1964-1968), página 128. 
dos sistemas de expresión: no existe material fílmico que sea puramente visual; aun en el caso de un producto en el que no se incluyan otros sonidos que no sean los ambientales, donde no exista un guión, donde la cámara simplemente registre lo que vaya ocurriendo, el modo que el director elija para manipular la cámara, el ángulo que escoja para filmar y la decisión de qué elementos conservará dentro del cuadro y cuáles dejará afuera constituyen también una manera de significar. En palabras de Jacques Aumont, toda obra de arte debe someterse a una lectura "polifónica" ${ }^{18}$, en la que los distintos componentes aportan sentido; el traductor debe servirse de esos aportes ofrecidos para aprehender la idea subyacente y transmitirla con eficacia y claridad al espectador.

En esta variedad de canales, o modos, de expresión, cada uno de ellos se vale de los elementos que le son inherentes para expresar significado. La modalidad escrita, por ejemplo, hace uso de los signos de puntuación y de su repetición para otorgar, respectivamente, una entonación o un énfasis particular a una frase o palabra: una enunciación excesivamente enérgica puede expresarse a través de mayúsculas; los insultos o el lenguaje soez, a través de símbolos preestablecidos; en algunas producciones, la tipografía escogida para los anuncios o los créditos anticipa el género del programa o la película. La modalidad sonoro-verbal, en cambio, se apropia de elementos como el tono de voz, la cadencia o la entonación para alcanzar su objetivo. Existe otro elemento que también aporta significado pero que no tendremos en cuenta en este análisis, y es el material sonoro-no verbal (la música de fondo y los ruidos ambientales o de trasfondo). La interacción entre estos dos modos de significar, el escrito y el sonoro, no siempre resulta fluida. Por ejemplo, en la elaboración de textos puramente escritos, los elementos del sistema sonoro no tienen, en muchas oportunidades, un equivalente puro en el otro sistema. Un escritor puede tener claro en su mente el tono de voz o la intención con la que uno de sus personajes debería pronunciar una frase; sin embargo, los medios gráficos con los que cuenta no son siempre suficientes para transmitir al lector su idea con claridad y debe recurrir a componentes indirectos para lograrlo. En estos casos, los verbos que

${ }^{18}$ Aumont, Jacques (1990), página 123. 
describen actos de habla y sus modificadores son excelentes aliados de los escritores, así como las acotaciones, o didascalias, lo son de los dramaturgos. Esto no quita, desde ya, que cada lector, actor o director entienda estos textos secundarios (me refiero a las didascalias y a los verbos, adjetivos o adverbios que describen los actos de habla) de manera personal, según la interpretación que haya hecho de la obra en cuestión. Lo mismo ocurre con las imágenes que los autores construyen en su mente y recrean en el texto a través de palabras.

En el caso de los textos audiovisuales, la relación es más colaborativa: los canales se complementan, se apoyan uno en el otro. De ahí que el recorte que pudiera llegar a efectuarse al elaborar un subtítulo no depende en absoluto del capricho del traductor, sino que, además de tener siempre como referencia el texto reproducido por los actores, la decisión de conservar o descartar determinados elementos en el pasaje al texto escrito se toma teniendo en cuenta el aporte de significado que haga el canal sonoro, ya sea a través de las inflexiones de voz de los actores o de la música y los sonidos. A esto se le suma el caudal semántico proveniente de las imágenes, tanto estáticas como en movimiento, que forman parte del material. Aunque no se pueda establecer con exactitud estadística el grado en que las imágenes influyen en el texto escrito traducido, es innegable que tal influencia existe $y$, en muchas ocasiones, por su cualidad de inalterable, el canal visual condiciona la tarea del traductor, quien en su rol de intérprete, puede tomarse la licencia de alterar completamente el texto de un subtítulo (y también de un texto para la modalidad de doblaje) para ajustarlo a una secuencia de imágenes. Pero, de más está decir, es imposible hacer lo contrario.

Vale reiterar, una vez más, que la multimodalidad se inserta dentro del campo de la semiótica social, y es este componente "social" el que agrega un matiz que complejiza aun más la tarea de transmitir significado en la traducción de textos audiovisuales. Por un lado, e independientemente de la intención del guionista o del director del material fílmico y de la interpretación del traductor, el significado que a su vez se le otorgue a esa otra interpretación que es la traducción estará influenciado, como postulaba Saussure, por los estereotipos del 
entorno cultural en el que se desenvuelva o al que pertenezca el receptor. Por otro lado, sin embargo, este no es el único factor que determina la interpretación del espectador. Frente a una expresión artística, en este caso un texto audiovisual narrativo, el espectador también desarrolla de manera intuitiva una percepción genérica que moldea sus expectativas con respecto a la obra y lo predispone a una determinada recepción ${ }^{19}$. Pensemos en el siguiente ejemplo: en los filmes o programas que se catalogan como ficción técnica (series como Bones, Doctor House, Grey's Anatomy), se utiliza información, a veces sumamente específica, perteneciente a un campo científico o técnico determinado. Ahora bien, esa "percepción genérica" provoca que el espectador de esa clase de programas en los que prima la ficción se concentre en la trama y preste escasa o nula atención a la precisión de los datos; en cambio, la "percepción genérica" de las personas que elijan mirar un documental sobre el mismo tema hará que estén más predispuestos a informarse o a adquirir conocimientos, y no simplemente a entretenerse. Ellos no esperan encontrar una trama interesante, sino datos precisos. Esto explica que la lectura que un mismo espectador efectúa de un material audiovisual con ciertas similitudes puede resultar muy distinta de acuerdo con el caso ${ }^{20}$. El recorrido retorna a Peirce: el receptor, al recrear el signo original, le adjudica significados aptos en relación con sus intereses (los que posiblemente difieran de los del director y guionista, o los del traductor) y construye el interpretante que le resulte más familiar o conveniente.

El análisis de los textos audiovisuales dentro del marco semiótico social de la multimodalidad permite distinguir los distintos sistemas que convergen en la expresión de significado, diferenciar las características singulares de cada uno de ellos y entender las influencias ejercidas unos sobre otros. Para lograr una versión precisa y eficaz, el traductor necesita sopesar los aportes de los canales visuales verbales y no verbales, y también los de los sonoros, y realizar una selección

\footnotetext{
19 Genette, Gerard (1989), página 13.

20 De todas maneras, siempre dentro del componente social que enmarca este análisis, quiero aclarar que la clasificación genérica que realiza el espectador no se rige por parámetros estrictos y es, en ocasiones, una interpretación personal. "En último término, la determinación del estatuto genérico de un texto no es asunto suyo [del texto], sino del lector, del crítico, del público, que están en su derecho de rechazar el estatuto reivindicado por vía paratextual". Genette, Gerard (1989), página 13.
} 
criteriosa de los contenidos. En esta tarea, le será de mucha utilidad el abordaje de un enfoque teórico adicional: la teoría de la relevancia, concepto que retomaremos más adelante.

\subsection{UN PÁRRAFO APARTE PARA LA INTERMEDIALIDAD}

Existen casos especiales en la traducción de subtítulos para material audiovisual que no se analizarán en profundidad en este trabajo, pero que merecen mínimamente algunas líneas. En términos generales, el proceso para la realización de un largometraje, corto, serie o programa de televisión de corte narrativo incluye una etapa en la que los guionistas elaboran el texto que permite sostener el relato cinematográfico, y otra en la que el director filma la interpretación que los actores y él mismo hayan hecho de ese escrito. Cuando el material audiovisual requiera de una traducción, el traductor hará su tarea basándose en el texto emitido por los actores (que no siempre coincide en un ciento por ciento con el guión original, tanto en la modalidad de doblaje como en la de subtitulado). Sin embargo, lo que importa resaltar aquí es que, más allá de cualquier modificación que pudiera efectuarse en la segunda etapa de ese proceso, el texto en cuestión, el guión, fue concebido desde su origen para una producción audiovisual.

La situación resulta diferente cuando se trata del subtitulado de versiones fílmicas de obras literarias, en las que el guión refleja o copia el texto original. Aquí el recorte que se efectúe para la elaboración de los subtítulos implicará probablemente el cercenamiento (quizá el término resulte exagerado, pero, en mi opinión, expresa con precisión el sentimiento del traductor) de la obra original, divulgada en extenso y conocida por gran parte del público que elige ver ese programa o película. En estos casos, a la conjunción de sistemas que interactúan aportando significado a través de vías distintas, se le agrega el traspaso de un 
medio (el escrito, el del libro, el literario) a otro (el visual, el cinematográfico). A este traspaso se lo conoce como intermedialidad.

Walter Berg, en su artículo "Literatura y cine. Nuevos enfoques del concepto de intermedialidad" ${ }^{21}$, ofrece dos definiciones que considero pertinentes para el tema de este trabajo. La primera sirve para diferenciar este enfoque del de multimodalidad: "[...] el concepto de intermedialidad no es el resultado de la adición de diferentes conceptos de medialidad ${ }^{22}$, sino que supone un proceso de integración de aspectos estéticos en un nuevo contexto medial". La segunda definición corresponde a un concepto propuesto por Jochen Mecke y Volker Roloff y se relaciona más íntimamente con el espíritu de mi análisis, ya que habla de un "intersticio [...] entre las imágenes que permite la circulación de imágenes y textos $^{23 "}$. Ese intersticio es el que da pie a la recreación del signo original, tanto por parte del traductor como del espectador.

Las versiones cinematográficas de obras literarias podrían compararse con un juego de cajas chinas: un texto puramente literario (la obra original) se inserta, en ocasiones tal como fue concebido, en otro texto escrito (el guión), el que a su vez se inserta en un texto audiovisual (el filme). La "copresencia" ${ }^{24 "}$ de textos provenientes de medios diferentes impone una exigencia adicional a la tarea del traductor, quien deberá circunscribir el texto inalterable de la obra original al formato y a la estimación de velocidad de lectura requeridos para la redacción de subtítulos. (Estos dos últimos conceptos, el del formato y el de la velocidad de lectura, se explicarán más adelante).

El caso más representativo con el que tuve la oportunidad de trabajar es el de la película de 1996: "Romeo + Juliet", del director Baz Luhrmann. En esta producción se observa claramente cómo un medio determinado (el drama teatral original) establece su presencia en otros de distinta índole (el guión

\footnotetext{
21 Berg, W. B. (2002), páginas 128 y 129.

22 El mismo concepto se define, según distintos autores, como "(multi)modalidad" o

"(multi)medialidad". Las itálicas pertenecen al original.

23 Berg, W. B. (2002), páginas 128 y 129. La cita corresponde a una traducción de la publicación Kino-/(Ro)Mania. Intermedialität zwischen Film und Literatur (1999).

24 Genette, Gerard (1989), página 10.
} 
cinematográfico y la película). En esta oportunidad, además, dado que la trama se inserta en un contexto varios cientos de años posterior al de la Inglaterra de fines del siglo $\mathrm{XVI}$, los parlamentos de la tragedia de William Shakespeare se reproducen con una velocidad de habla mucho más veloz que la impuesta por el tono declamatorio del teatro.

Tomemos como ejemplo la conversación entre Romeo y su primo, Benvolio. La escena transcurre desde el minuto 11'46" hasta el 12'45" de la película; es decir, tiene una duración de 59 segundos. En ese lapso, los actores pronuncian 170 palabras del texto original de la obra de Shakespeare, las que suman 863 caracteres, teniendo en cuenta también los espacios que separan las palabras. En términos generales, se considera que el espectador promedio es capaz de leer y comprender alrededor de 140 palabras por minuto. Sin embargo, hay estudios que aseguran que la velocidad de lectura varía de acuerdo con el idioma en que esté escrito el subtítulo. José Luis Martí Ferriol, por ejemplo, en su artículo "Subtitle reading speeds in different languages: the case of Lethal Weapon", publicado en 2013 en Quaderns. Revista de Traducció 20 de la Universitat Autònoma de Barcelona, afirma que, cuando se trata del idioma español o del alemán, la cantidad de palabras leídas y comprendidas por minuto desciende (120 palabras por minuto); en cambio, en inglés y en francés, el número aumenta considerablemente (150 palabras por minuto). Queda claro, entonces, que el parlamento de la película en su versión en inglés supera la cantidad establecida para el espectador promedio. En la versión que Pablo Neruda tradujo al castellano, y que yo utilicé para la película, el texto consta de 147 palabras, número que también supera la velocidad media de lectura en ese idioma. Estas circunstancias cuantitativas colocan al traductor de subtítulos en la eterna disyuntiva entre la fidelidad hacia el autor o hacia el receptor de la obra, respetando a pies juntillas el texto original o adaptándolo, respectivamente. (No olvidemos, además, que cada subtítulo contiene, en términos generales y como máximo, 2 líneas de 35 caracteres cada una, contando los espacios entre palabras). $\mathrm{Si}$ el traductor decide que el texto traducido en formato de subtítulos debe respetar con total rigor la versión en castellano elegida por él de la obra 
dramática, ya que, como define Peter Newmark, se trata de un "texto de autoridad" 25 , es probable que al espectador se le dificulte la triple tarea de apreciar las imágenes, leer los subtítulos y absorber su contenido. Si, en cambio, el traductor sopesa las alternativas y decide que la comprensión y el disfrute del espectador están por encima del respeto reverencial que se le pueda tener a la obra, la relación que el espectador establezca con el texto visual verbal y no verbal resultará más fluida.

A continuación, y a modo de ejemplo, ofrezco el texto original del guión en inglés (el que reproduce fielmente la versión de Shakespeare), la versión de Neruda y una versión del texto traducido en formato de subtitulado. Para comprender la complejidad a la que se sometería al espectador, téngase en cuenta que cada subtítulo con 35 caracteres con espacio, ya tenga una o dos líneas, no permanece más de 4 o 5 segundos en pantalla y que la cantidad de subtítulos debe leerse en los mismos 59 segundos que transcurre la escena en la película en su versión original.

\section{TEXTO EN INGLÉS}

BENVOLIO

Good morrow, cousin.

ROMEO

Is the day so young?

BENVOLIO

But new struck, coz.

ROMEO

Ay me, sad hours seem long. Was that my father that went hence so fast?

${ }^{25}$ Newmark, Peter. A Textbook on Translation. (1998) 


\section{BENVOLIO}

It was. What sadness lengthens Romeo's hours?

ROMEO

Not having that which having makes them short.

BENVOLIO

In love?

ROMEO

Out.

BENVOLIO

Of love?

ROMEO

Out of her favour where I am in love.

BENVOLIO

Alas that love, so gentle in his view, should be so tyrannous and rough in proof.

\section{ROMEO}

Alas that love, whose view is muffled still, should without eyes see pathways to his will. Where shall we dine? O me! What fray was here? Yet tell me not, for l've heard it all. Here's much to do with hate, but more with love. Why, then, O brawling love, $O$ loving hate! $O$ anything of nothing first create! $O$ heavy lightness, serious vanity! Misshapen chaos of well-seeming forms! Feather of lead! 


\section{BENVOLIO}

¡Has madrugado, primo!

ROMEO

¿Es tan temprano?

BENVOLIO

Recién suenan las nueve.

ROMEO

Largas me parecen las tristes horas. ¡Ay! ¿Era mi padre el que tan rápido partió de aquí?

\section{BENVOLIO}

Él era, pero, dime, ¿qué tristeza hace largas las horas de Romeo?

ROMEO

El no tener lo que las hace cortas.

BENVOLIO

¿Enamorado?

ROMEO

Sin que...

BENVOLIO

¿Del amor?

ROMEO

Sin que me corresponda la que amo.

BENVOLIO 
Ay, ¿por qué el amor que parece tan dulce cuando se prueba, es áspero y tirano?

\section{ROMEO}

¿Cómo el amor con la vida vendada puede ver el camino que nos lleva? ¿Hoy, dónde comeremos? ¡Ah! ¿Una gresca hubo aquí? No respondas. Lo comprendo. Hay que hacer mucho por el odio aquí y hay mucho más que hacer por el amor. ¿Por qué el amor que riñe? ¿El odio que ama? ¡Y de la nada todo fue creado! ¡Vanidad seria! ¡Levedad pesada! ¡Informes casos de agradables formas! ¡Pluma de plomo!

\section{TEXTO EN FORMATO DE SUBTITULADO}

¡Has madrugado, primo!

-¿Es tan temprano?

-Recién suenan las nueve.

Largas me parecen

las tristes horas.

¡Ay! ¿Era mi padre el que tan rápido partió de aquí? 
Él era, pero, dime...

¿qué tristeza hace largas

las horas de Romeo?

El no tener

lo que las hace cortas.

-¿Enamorado?

-Sin que...

¿Del amor?

Sin que me corresponda

la que amo.

Ay, ¿por qué el amor que parece

tan dulce cuando se prueba,

es áspero y tirano? 
¿Cómo el amor

con la vida vendada

puede ver el camino

que nos lleva?

¿Hoy, dónde comeremos?

¡Ah! ¿Una gresca hubo aquí?

No respondas. Lo comprendo.

Hay que hacer mucho

por el odio aquí

y hay mucho más que hacer

por el amor.

¿Por qué el amor que riñe?

¿El odio que ama? 
¡Y de la nada todo fue creado!

¡Vanidad seria!

¡Levedad pesada!

¡Informes casos de agradables

formas! ¡Pluma de plomo!

Para concluir, quisiera señalar que el hecho de que se haya adaptado la estética y la dinámica de la historia a las de una película contemporánea de acción, por un lado, predispone al espectador a enfrentar un ritmo vertiginoso, muy lejano al de las representaciones teatrales del siglo XVI, y, por otro, subraya el anacronismo de los parlamentos y pone al texto aun más de manifiesto, al contraponerlo con las imágenes de la película. Esto retoma la idea de la percepción genérica de la que hablaba Genette.

\subsection{EL SUBTÍTULO, UNA IMAGEN ENTRE TANTAS}

Arlindo Machado en su artículo "Todos los films son extranjeros" ${ }^{26}$, sostiene que "Se pueden considerar los subtítulos como objetos extraños, una intrusión en el espacio fílmico [...] La lectura de subtítulos exige del espectador cierto esfuerzo intelectual, cierto alejamiento con relación a la diégesis que, en cierta medida, puede entrar en conflicto con el placer de la experiencia cinematográfica" ${ }^{27}$. Esta afirmación coincide con la comparación que una vez estableció un traductor argentino con amplia experiencia en la traducción de textos audiovisuales en

26 Machado, Arlindo (2009), página 111.

27 Machado, Arlindo (2009), página 112. 
cuanto que los subtítulos eran manchas en un cuadro y corrompían la obra original. Es innegable que la inserción de subtítulos agrega un escollo al espectador que no comprende la lengua de origen del material audiovisual, ya que debe sumar una actividad más a las de observar, escuchar, interpretar y disfrutar lo que se ofrece frente a sus ojos. Sin embargo, dado que, en estos casos, no se puede prescindir de la ayuda que ofrece esa "mancha" denominada subtítulo y que todavía es una utopía pensar en algún método que logre que pase inadvertido (siempre existe la posibilidad de optar por la modalidad de doblaje, pero el debate sobre la conveniencia o no de aplicar una técnica en oposición con la otra no forma parte del presente trabajo), considero extremadamente más práctico resignarse a su presencia e intentar sacar el mayor provecho de ella.

Mi primera propuesta es revertir el postulado anterior y pensar los subtítulos no como una molestia, sino como un beneficio a disposición del espectador. Aunque la frase "algo es mejor que nada" puede resultar controvertida y merecedora de toda crítica en ciertas oportunidades, sí se ajustaría muy bien a esta situación. Para los espectadores, sería imposible acceder a la filmografía universal de cualquier género si se prescindiera de los subtítulos o del doblaje. Siempre en términos visuales, un subtítulo es una imagen estática sobreimpresa en otra, dinámica y de mayor tamaño; por otra parte, esta imagen estática del subtítulo convive en la escena fílmica con otras imágenes, también estáticas (carteles, publicidades, señales, cartas, etiquetas, etcétera, que pudieran aparecer en el material audiovisual), y todas se complementan para construir el significado de la obra. La búsqueda de un método traslativo perfecto del texto es una quimera inútil y una pérdida de tiempo: lo que se pretende es que el resto del mundo tenga acceso al material audiovisual producido por el otro resto del mundo. El secreto reside en sacar provecho de lo que los diversos canales de significado puedan ofrecer con el fin de optimizar ese "algo" y que sea "mucho mejor que nada".

A diferencia de las otras imágenes estáticas, el subtítulo se ubica casi siempre en la misma posición: el centro inferior de la pantalla. Algunos protocolos 
de subtitulado requieren que la línea (o la segunda línea, en el caso de que el subtítulo esté conformado por dos) se ubique a una altura equivalente a la doceava parte de la altura total de la pantalla, sobre el borde inferior ${ }^{28}$. En ocasiones, pueden producirse desplazamientos de subtítulos, pero estos corresponden a casos excepcionales y se deben a exigencias impuestas por determinadas características del material (la aparición simultánea en la pantalla de un gráfico y un subtítulo; un color de fondo en la parte inferior del material que no permita el contraste con las letras del subtítulo; entre otros). Que el subtítulo se ubique en una posición prefijada facilita la tarea del espectador, quien ya debe realizar el esfuerzo de adaptar su visión del entorno natural en el que se encuentra a la visión de un espacio artificial, el de la pantalla de cine o televisión. Hay autores que señalan que las personas no contemplan las imágenes de manera global, sino a través de fijaciones sucesivas que no duran más de unos segundos; $y$, cuando la persona mira la imagen sin ningún propósito en particular (como cuando un científico examina un elemento a través de un microscopio), estas fijaciones se concentran exclusivamente en las partes con mayor carga informativa. Saber de antemano que el subtítulo contiene la información necesaria para la comprensión del texto audiovisual en un idioma extranjero y cuál es su ubicación allana notablemente la labor del espectador.

De acuerdo con la tesis de Rudolf Arnheim en su libro "El poder del centro", ver una imagen equivale a organizar los diversos centros que la constituyen en función del centro primordial, el espectador. La diferenciación que establece Arnheim entre la contemplación visual que promueve la dimensión vertical (la televisión) en contraposición con la participación activa intrínseca a la dimensión horizontal (el teatro) sirve también para entender por qué la visión distanciada y frontal del que observa un cuadro o un tapiz colgados, o mira una pantalla de cine o televisión, facilita la exploración del objeto en su totalidad y la consiguiente organización visual ${ }^{29}$ : en un medio plano y vertical, "el espectador actúa

\footnotetext{
28 Karamitroglou, Fotios. (1998) página 2

29 Arnheim, Rudolf (1984), página 25
} 
verdaderamente como centro de anclaje de la situación perceptual" ${ }^{30}$ Asimismo, el hecho de que el espectador de cine o televisión - a diferencia del que observa un cuadro o una escultura en un museo- sea estático y no dinámico, elimina las relatividades que pudieran ofrecer los distintos puntos de vista y permite una mayor claridad de la estructura del campo visual. Estas ideas coinciden con la del espectador como vértice de las perspectivas de la imagen general, un concepto que se retomará más adelante.

“[...] Arnheim estudia desde este ángulo la relación entre un espectador concebido según el modelo de un 'centro' imaginario que refiere enteramente a sí mismo el campo visual, y una imagen en la que, desde ese momento, desempeñan un papel preponderante los fenómenos de centrado. La tesis de Arnheim es interesante por el grado de generalidad que él le confiere; para él, hay en la imagen varios centros, de diversas naturalezas - centro geométrico, 'centro de gravedad' visual, centros secundarios de la composición, centros diegético-narrativos - y la visión de las imágenes [...] consiste en organizar estos diferentes centros en relación con el centro 'absoluto' que es el sujeto espectador." 31

El papel del receptor es esencial para la función inherente del subtítulo. Para que una imagen exista debe haber un espectador que la aprecie, analice o descifre. En otras palabras, el espectador es artífice de la imagen -en este caso, el subtítulo- Como ocurre con toda imagen, este vínculo dependiente y vital contiene tres valores que relacionan al espectador con la realidad que la imagen representa. Uno es el valor de representación: el texto que aparece en el centro inferior de la pantalla representa los parlamentos emitidos por los actores. E segundo es el valor de símbolo: las imágenes simbólicas identifican conceptos abstractos y este valor se evidencia claramente en el material de animación (por ejemplo, la siguiente combinación "!@\#\$\%" es símbolo de que el personaje que las enuncia está diciendo algún tipo de improperio) o en el subtitulado para sordos

\footnotetext{
Arnheim, Rudolf (1984), página 60

31 Aumont, Jacques (1990) página 157
} 
(la inclusión de una clave de sol es símbolo de que se oye una canción, o las mayúsculas son símbolo de que la persona está gritando). Por último, el valor de signo: el subtítulo es un signo sujeto a la interpretación del receptor.

Además de estos valores que las vinculan con el receptor, las imágenes cumplen funciones, tienen razones de ser. En el caso de los subtítulos, su función podría definirse como exclusivamente epistémica, dado que la inclusión de esta imagen verbal no contempla otro propósito más que el de transmitir conocimiento, lo mismo que sucede con un mapa o un naipe. El resto de las imágenes estáticas que aparecen en un material audiovisual pueden poseer, aparte de la epistémica, funciones simbólicas y estéticas.

En parte, el rol activo o "constructivista" que adopta el espectador está regido por la carga informativa que acarrea consciente $o$ inconscientemente y que fue aumentando a lo largo de su vida. La mirada del espectador no es inocente: está influenciada por sus conocimientos previos y por los estereotipos forjados por la cultura, o las culturas, que lo han traspasado, lo que afecta su modo de percibir. En otras palabras, uno no se aproxima virgen a una imagen, sino que compara lo visto con lo que esperaba ver. El significado de una imagen se determina tanto por sus características ópticas, que también dependen de la experiencia perceptiva del espectador, como por sus características ontológicas, influenciadas en ocasiones por la cultura, y por sus características convencionalizadas. En palabras de Eco, "se pueden individuar bloques de unidades expresivas que remiten no tanto a lo que SE VE del objeto, sino a lo que SE SABE o a lo que se ha aprendido a ver" ${ }^{\prime 2}$. Frente a una imagen, el espectador la reconoce y rememora lo que sabe de ella, o bien, se somete al impulso de lo que la imagen le suscita; se establece una confrontación entre la hipótesis establecida con anterioridad por la mente y los datos que proporcionan los sentidos ${ }^{33}$. Veamos un ejemplo: las películas situadas en un entorno histórico marcadamente lejano al contemporáneo. A través de distintos elementos sonoros y visuales (el vestuario, el maquillaje, los decorados,

\footnotetext{
32 Eco, Umberto (2000), página 307. Las mayúsculas pertenecen al original.

33 John M. Kennedy definió a esto como "la regla del etcétera" (Aumont, Jacques, 1990, página 92): el espectador suple la información ausente en la imagen con la ayuda de sus saberes previos. En el caso del subtítulo, este saber previo llega no sólo a través del canal visual verbal, sino de los otros canales visuales, y también de los sonoros, presentes en el material audiovisual.
} 
los medios de locomoción, la música), el espectador percibe que la narración transcurre, supongamos, en el Medioevo. Su experiencia y bagaje cultural le indican que, en esa época, el tono de las conversaciones y el tratamiento entre las personas era más formal y distante, y que ciertos elementos hoy cotidianos todavía no habían sido inventados. Por eso es que, en ese contexto, no le resulta llamativo escuchar diálogos acartonados o con un vocabulario en desuso, sensación que sí tendría si la historia se situara en la actualidad (como señalé en la mención a la película "Romeo + Juliet"). Un caso similar es el del material audiovisual ambientado en un entorno futurista.

Eco propone que la relación que se establece entre signo y significado es transitoria y está determinada por un código particular en una circunstancia particular $^{34}$. Este concepto, sumado al anterior y al de la aceleración del proceso interpretativo que propone la teoría de la relevancia, abonaría la implementación de estereotipos familiares en la cultura de destino en la traducción con formato de subtítulos, con el fin de facilitar y hacer más eficaz la lectura de un texto de aparición tan fugaz. A pesar de la oposición de algunos autores como Arlindo Machado, quien, desde una postura en defensa de la diversidad cultural, considera que el estereotipo es una "domesticación de la otredad", "un recurso sutil para ejercer censura ${ }^{35}$ ", es imposible no reconocer su claridad interpretativa. El espectador identificará más rápidamente el origen de un personaje si este habla con el acento "esperado" de dicha nacionalidad en su idioma; de la misma manera, comprenderá sin mayor esfuerzo que un personaje chino, japonés, vietnamita, etcétera, tiene dificultades para hablar el español si en el subtítulo se reemplazan las letras "r" por "l", más allá de que los inmigrantes de determinados países asiáticos cometan ese error fonético o no.

En cuanto a la relación entre texto e imagen, Roland Barthes afirma que, desde la aparición del libro ilustrado, se estableció un fuerte vínculo entre ambos elementos, pero que, a pesar del tiempo transcurrido, ese vínculo no ha sido estudiado en profundidad desde el punto de vista estructural; es decir, de "la

\footnotetext{
34 Eco, Umberto (2000), página 84.

35 Machado, Arlindo (), páginas 116 y 117 respectivamente. Las itálicas pertenecen al original.
} 
estructura significante de la ilustración"36. En este sentido, uno de los aspectos que los traductores se plantean en el momento de establecer un recorte en el texto original es si la relación del subtítulo (el texto) con las imágenes móviles o estáticas dentro del texto audiovisual (las ilustraciones) es o no tautológica, ya que a veces lo expresado por el actor a través de las palabras repite el mensaje transmitido por sus gestos. En estos casos, la disyuntiva que se plantea es si el texto refuerza la imagen, si la inclusión del texto es innecesaria dada la transparencia del mensaje gestual o si se debe reelaborar el texto en concordancia con la expresión. Un ejemplo hipotético: un personaje le pregunta a otro si va a revelarle un código secreto, a la vez que lo amenaza con un arma; la víctima no sólo dice que sí, sino que sacude claramente la cabeza en señal de afirmación. En esta circunstancia, ¿es necesario agregar el subtítulo "Sí" a continuación de la pregunta? ¿O es una redundancia? Algunos profesionales se inclinan por incluir la respuesta para mantener la dinámica coherente del discurso y no provocar en el espectador que desconoce totalmente la lengua del original la sensación de que se lo está privando de información; en cambio otros proponen eliminarla para reducir al mínimo indispensable el esfuerzo al que se ve sometido el espectador al leer los subtítulos. Esta discusión obviamente no se suscita cuando el texto brinda información que la imagen no aporta; de todas maneras, sería conveniente recalcar que, aunque es cierto que el texto y la imagen se complementan, no forman un todo, y que únicamente cobran sentido dentro de la historia que ayudan a contar. Retomando los conceptos de Barthes en su "Retórica de la imagen", texto e imagen se relevan con el propósito de lograr que la transmisión del mensaje sea más eficaz. En este relevo, el texto escrito aporta un valor denotado, mientras que el resto de los canales de información, entre ellos el visual no verbal, hacen lo propio con el valor connotado. Si pensamos en el ejemplo anterior, un actor puede emitir un claro y rotundo "Sí", pero la información que llega al espectador a través de los demás canales visuales y sonoros deja en claro que esa afirmación no es tal y que el sentido verdadero de esa respuesta es otro y subyace en sus gestos y en su tono de voz. De todas maneras, es

36 Barthes, Roland (1964) página 6 
necesario advertir y reiterar que los valores connotativos asignados por el espectador no son caprichosos, sino que están basados en sus saberes previos y condicionamientos culturales.

En síntesis, después de este análisis, queda explícito que el subtítulo correctamente elaborado no es una mancha, sino una colaboración. Por su posicionamiento estratégico, su vínculo con el receptor, su función, su aporte de información y su relación con la imagen en movimiento, el subtítulo siempre contribuye al disfrute de la diégesis del texto audiovisual.

\subsection{UNA RELACIÓN CON ALGUNAS RISPIDECES}

Como ocurre con cualquier otra clase de relación, la que se establece entre texto e imagen transita por planicies y depresiones. Las planicies o zonas de contacto ya se hicieron explícitas en las secciones anteriores: tanto el canal visual verbal como el visual no verbal aportan significados que se refuerzan o complementan.

Pero antes de zambullirme en un análisis más profundo del texto en forma de subtitulado, quisiera detenerme muy brevemente en las depresiones o zonas de conflicto.

En primer lugar, la diégesis del material audiovisual se expresa básicamente a través de dos modalidades de relato (insisto en que no me dedicaré al canal sonoro en este trabajo). Una es la mímesis, en la que se imitan los gestos, las palabras y la manera de hablar de aquellos a quienes se quiere representar; y otra es la expresión visual, lo que se muestra. En la literatura, la diferencia entre lo mimético y lo visual se pone de manifiesto a través de los diálogos y los fragmentos descriptivo-narrativos, respectivamente. En el cine, las imágenes estáticas y en movimiento reemplazarían a los últimos. Para que no se susciten controversias en el plano narrativo, el accionar, muchas veces simultáneo, de ambas modos de significar, el que cuenta y el que muestra - 
showing and telling, según la terminología propuesta por André Gaudreault ${ }^{37}$-, debería ser sincrónico y coherente, a menos que exista una intención expresa de generar una situación absurda. Por otra parte, es necesario que el traductor evalúe qué conceptos se transmiten con mayor eficacia y claridad en cada modalidad de relato para no saturar al espectador con información redundante. Esta primera zona de conflicto ya se analizó en el punto anterior.

Asimismo, la confluencia de informaciones similares puede generar otra zona de conflicto diferente, ya que la evaluación que el traductor realice y su posterior elección siempre estarán marcadas por su propio punto de vista, independientemente de la objetividad que le otorguen su experticia y su profesionalismo. En este aspecto, mirar una película o un programa de televisión podría compararse con el juego del "teléfono descompuesto", en el que cada participante narra al de su derecha lo que recuerda o comprende del mensaje que le acaba de transmitir el que está a su izquierda. ¿Por qué planteo esta analogía? La primera subjetividad la genera el mismo director de la película o del programa; el modo en que enfoca la cámara o monta las imágenes, o los planos que elige, su lectura del guión, expresan significado. El actor aporta también su propia visión a la interpretación del texto. El traductor de subtítulos, por su parte, decide qué elementos rescata, cómo los recrea y cuáles descarta del plano verbal y visual. Por último, el espectador se apropia de todas estas interpretaciones y efectúa, a su vez, una lectura personal. En esta cadena, es el traductor quien debe esforzarse por no dejarse llevar por su capacidad interpretativa y acercarse lo máximo posible a la visión de los creadores originales (el guionista, el director) para que la versión que reciba el espectador se corresponda con la primitiva.

Ahí reside la última zona de conflicto, que puede generarse en relación con lo que acabo de señalar: la subjetividad propia del espectador. La apropiación consciente e inconsciente que cada persona hace de los simbolismos presentes en las imágenes, tanto móviles como estáticas, está anclada en su cultura, y por lo tanto, no es unánime.

7 Aumont, Jacques (1990) página 258 
"[...] la imagen es siempre modelada por estructuras profundas, ligadas al ejercicio de un lenguaje, así como la pertenencia a una organización simbólica (a una cultura, a una sociedad). [...] La imagen es universal, pero siempre particularizada." ${ }^{38}$

38 Aumont, Jacques (1990) página 138 


\section{SUBTITULADO CONVENCIONAL}

\subsection{UNA DESCRIPCIÓN MÁS DETALLADA}

Debo aclarar que la clasificación de "convencional" es personal; hasta donde conozco, ningún especialista en traductología o en teorías relacionadas con la traducción de subtítulos utiliza esta denominación. Pero a mí me resulta útil para diferenciar el subtitulado que estamos acostumbrados a encontrar en el cine o en la televisión de sus variantes: el subtitulado para sordos e hipoacúsicos, el subtitulado en vivo y el sobretitulado en funciones teatrales o espectáculos de ópera.

El subtitulado convencional reproduce los parlamentos de los actores, locutores, narradores en off y, en el caso de los programas o películas de corte documental, los testimonios de los entrevistados o de las personas intervinientes, de manera literal o efectuando un recorte de la palabra dicha. El traductor de subtítulos toma la decisión de efectuar o no dicho recorte sobre la base de ciertas limitaciones técnicas que esta modalidad impone. Retomaré este tema unos párrafos más adelante. Lo que me interesa ahora es ahondar en las diferentes aristas que propone la idea del "recorte".

En su libro, "Teoría y práctica de la subtitulación inglés/español”, Jorge Díaz Cintas explica lo siguiente:

"[En un texto subtitulado] las reducciones pueden ser de dos tipos: parciales, en cuyo caso nos encontramos ante lo que se conoce como condensación o concisión; y totales, que se identifican con la eliminación, omisión o supresión de material ${ }^{39}$."

Como mencioné en secciones anteriores, el traductor no siempre se enfrenta a la necesidad de reducir el texto original. En muchas oportunidades, el subtítulo es una transcripción literal de lo que se escucha o se lee en pantalla. Sin

39 Díaz Cintas, Jorge (2003) página 202 
embargo, en muchas otras, ya sea por la dinámica de los diálogos, la velocidad de elocución o el desorden sintáctico del hablante, el traductor debe sintetizar o reelaborar el texto original. La opción de condensar el texto implica, por ejemplo, el empleo de vocablos más resumidos (pedir en vez de solicitar), de apócopes (foto en vez de fotografía), de pronombres en reemplazo de sintagmas nominales o incluso de oraciones completas - cuando el referente esté claramente explícito-, de tiempos verbales simples en lugar de compuestos y la simplificación de estructuras sintácticas (¿Compartimos el asiento? en vez de ¿Te molestaría compartir el asiento conmigo?). Cuando el traductor decide suprimir material, puede hacerlo de manera drástica o sutil. La primera modalidad supone la eliminación de oraciones o frases enteras; esto se da únicamente en casos extremos y tras la evaluación, por parte del traductor, de la relevancia del texto que va a omitir. La supresión sutil de material es una práctica mucho más frecuente en la que se eliminan elementos con una carga informativa o expresiva nula o escasa; a saber: repeticiones innecesarias, vocativos, interjecciones, expresiones de cortesía o mero valor fáctico que no aportan información sustancial a la narración (muletillas, frases como ¿qué tal? después de un ¡Hola!, las preguntas retóricas o question tags, como se las conoce en inglés), conectores innecesarios.

La imposición de realizar un recorte se origina en las propias características de la modalidad de subtitulado. En la sección "Un párrafo aparte para la intermedialidad", me explayé sobre el concepto de velocidad de lectura y su relación con la cantidad de caracteres que pueden aparecer en pantalla. Jacques Aumont señala que no se debe confundir "el tiempo perteneciente a la imagen y el que pertenece al espectador" ${ }^{\prime 4}$, ya que la ecuación varía de acuerdo con el objeto observado. Cuando recorremos un museo o visitamos una exposición, somos libres de detenernos el tiempo que queramos frente a una imagen y de observarla de cualquier manera y desde cualquier punto de vista. No obstante, ante un proyección, las condiciones se modifican: al tiempo que nos insume la lectura del texto escrito en sí, debemos sumarle el tiempo que nos toma la exploración

40 Aumont, Jacques (1990) página 171 
inconsciente, natural, de las imágenes visuales en pantalla, lo que nos permite comprender la situación en la que se inserta ese texto. Es decir, antes de la lectura específica del subtítulo, se produce, necesariamente, otra lectura, la lectura global de todos los elementos coexistentes. Además, la libertad del espectador de un producto audiovisual subtitulado se ve restringida por determinadas consignas que rigen su exploración, como la obligación de tener que leer el texto en pantalla en el momento y durante el tiempo que se le presentan (entre 2 y 7 segundos como máximo).

Con respecto a la cantidad de caracteres, quisiera agregar algunas precisiones. Es cierto, como mencioné, que en términos generales se establece un máximo de 35 caracteres por línea (no más de dos líneas por subtítulo), teniendo en cuenta los espacios entre palabras. Sin embargo, por mi experiencia de más de 20 años como traductora de subtítulos, sé que los protocolos de las empresas varían y que se exigen parámetros entre 32 y 45 caracteres por línea, con los espacios. Uno de los aspectos técnicos que más influye en la extensión de los subtítulos es la aparición simultánea de gráficos en la pantalla. Este problema ocurre mayormente en materiales con función didáctica o informativa, en los que es usual la inclusión de carteles con datos sobre la persona que está hablando o el objeto o el lugar que se muestra junto al subtítulo que traduce la locución del entrevistado, testigo o narrador. En estos casos, la extensión del subtítulo puede reducirse hasta la mitad de los caracteres.

Otra limitación técnica está relacionada con la inserción del subtítulo. Cada vez es más usual que se contrate a un traductor no solo para elaborar los subtítulos, sino para que los "temporice" o "queme" en pantalla. Paso a explicar de manera muy superficial estos dos términos para los lectores de este trabajo que no estén familiarizados con la tarea de subtitular material audiovisual. "Temporizar" significa configurar mediante un software específico el momento exacto en que cada subtítulo debe aparecer o desaparecer en la pantalla, en sintonía con el comienzo y el final de las locuciones de los hablantes; "quemar" un subtítulo es fijarlo en la pantalla (esta tarea le corresponde al traductor encargado de corregir la versión final, definitiva, del material). Por ello, en la actualidad, el 
traductor de subtítulos debe estar atento tanto a cuestiones lingüísticas como técnicas y efectuar también recortes impuestos por el tiempo de exhibición del texto en pantalla, los cambios de escena o fotogramas, la inclusión de imágenes estáticas, los requisitos de cada software, entre otras razones.

Con relación a los problemas de índole técnica, un detalle para tener en cuenta son los colores de fondo del sector de la pantalla donde se ubica el subtítulo. Recuerdo casos en los que, como espectadora, tuve dificultades para leer el texto, dado que se había insertado el subtítulo (usualmente escrito con letras blancas) sobre un campo poblado de margaritas o una superficie de arena clarísima. El caso quizá más emblemático de los últimos años es el de la película "Buenas noches y buena suerte", de 2005, exhibida totalmente en blanco y negro, en la que leer los subtítulos constituía una misión extenuante y, la mitad del tiempo, imposible. Permítanme compartir un comentario publicado por esos días en un blog con respecto a este problema (comentario al que adhiero en un ciento por ciento): "Advertencia: a los que no hablen inglés, mejor verla doblada, porque nadie atinó a pensar que los subtítulos clásicos blancos no se ven en una película en blanco y negro. ¿Alguien sabe que inventaron los subtítulos amarillos para estos casos?" El contraste permite que el texto se destaque, lo que facilita la lectura del espectador.

"Nuestro sistema visual está, de hecho, equipado para detectar no tanto luminancias como cambios de luminancia; la luminosidad (psicológica) de una superficie está casi totalmente determinada por su relación con el entorno luminoso; está en función especialmente de su fondo (...). Dos objetos parecerán tener la misma luminosidad si su luminancia relativa en relación con su fondo es la misma, cualesquiera que sean los valores absolutos de estas luminancias; inversamente, un mismo objeto, idénticamente iluminado (emisor, pues, de la misma luminancia) será juzgado más luminoso ante un fondo más oscuro. ${ }^{41 "}$

41 Aumont, Jacques (1990) páginas 30 y 31 
Lo que describe Aumont hace referencia a una reacción natural del aparato visual frente a un estímulo determinado. Sin embargo, cuando se trata del ser humano, el hecho de mirar deja de ser una acción puramente inconsciente para convertirse en un modo de percibir el entorno; en el caso de los textos audiovisuales, el entorno delimitado de la pantalla. Aun cuando posemos los ojos en una imagen sin ninguna intención en particular, nuestra mirada no vaga libremente, sino que se concentra en los elementos más contundentes o con mayor cantidad de información ${ }^{42}$. Esta búsqueda se vuelve más perspicaz cuando existen consignas previas que guían la exploración visual. Frente a un material audiovisual subtitulado, la vista se prepara de antemano para escanear la imagen y hallar el texto escrito. Para que este escaneo sea rápido y eficaz, el subtítulo debe ubicarse siempre en el mismo sitio. La convención que dicta cuál es la posición óptima para insertar el subtítulo se rige de acuerdo con ciertos principios lógicos. Como expliqué en la sección "El subtítulo, una imagen entre tantas", se aconseja que la única línea del subtítulo, o la segunda, en el caso de que la hubiese, se ubique a una altura equivalente a la doceava parte de la altura total de la pantalla, sobre el borde inferior, para, por un lado, ocupar el menor porcentaje posible de pantalla con elementos ajenos al material original $y$, por otro, evitar que el ojo del espectador se esfuerce desplazándose hasta un extremo demasiado lejano. Nótese también que los subtítulos se ubican sobre el eje central, donde se desarrolla principalmente el núcleo de la acción dramática. Esta posición convencional tiene anclaje en, por lo menos, dos posturas teóricas. En "El poder del centro", Rudolf Arnhein analiza cuestiones físicas que abonan la decisión de ubicar el subtítulo en un determinado lugar. Por un lado, la fuerza gravitatoria. La atracción que ejerce el magnetismo de la Tierra hace que resulte más natural realizar movimientos descendentes que ascendentes (si vamos caminando por la calle, dirigiremos la vista hacia adelante o hacia abajo y solo elevaremos la mirada si algo nos llama la atención, y el esfuerzo que esta acción implicará siempre será mayor que en el de los otros dos casos). Por el otro, la direccionalidad lateral del campo visual. La tendencia del espectador es comenzar la exploración visual del

42 Este concepto se complementa con los elaborados a partir de la página 25 de este trabajo. 
texto escrito desde la izquierda hacia la derecha, antes de que desde arriba hacia abajo, y organizar la estructura de la imagen también en esta dirección; en este caso, la influencia cultural determina el movimiento (por ejemplo, en Occidente leemos de izquierda a derecha). Por último, la ubicación central y simétrica del texto (simetría establecida, en parte, por el marco que ofrece la pantalla) corresponde a la tradición de posicionar la parte más relevante de una obra en ese lugar (en el arte, era el lugar de privilegio para los dioses, los santos, los monarcas).

Otra de las teorías dice que, si analizamos la imagen en términos de perspectiva, vemos que las líneas perpendiculares al plano convergen siempre en un centro que se corresponde con la posición del observador. La irrupción del concepto de la perspectiva en las artes visuales durante el Renacimiento modificó el foco de atención que había predominado en la época medieval. El viraje humanista que se produjo durante el Renacimiento trasladó el eje desde el punto de donde irradian "los rayos celestiales" —el arte medieval, en especial el arte gótico, estuvo influenciado por la estética de la luz que consideraba a esta última como representación de la belleza divina- hacia el punto en donde convergen: es decir, ese punto fijo y estático que es el espectador ${ }^{43}$. Martin Jay habla de la "perspectiva cartesiana" del Renacimiento, que privilegiaba al individuo situado fuera del mundo (el espectador de cine o televisión) y que se conformaba con contemplarlo desde la distancia.

No obstante, el traductor a veces se ve obligado a renunciar a esa ubicación ideal y debe reposicionar el subtítulo en algún otro punto de la pantalla. Esta modificación se impone cuando se produce la aparición simultánea de un subtítulo y la de un gráfico o cartel. La superposición de textos escritos puede evitarse de distintas maneras. En el caso de los gráficos mencionados con anterioridad, los que contienen información sobre personas, objetos o lugares que aparecen en pantalla o a los que se hace referencia, o en el de los subtítulos intralingüísticos, cuando las interferencias sonoras dificultan la comprensión de lo que se dice, o durante la aparición de los créditos de apertura o finales, el subtítulo

43 Jay, Martin (2007) páginas 48 y 49 
puede desplazarse hacia el extremo superior central, el extremo inferior izquierdo o el extremo inferior derecho, según la ubicación del gráfico.
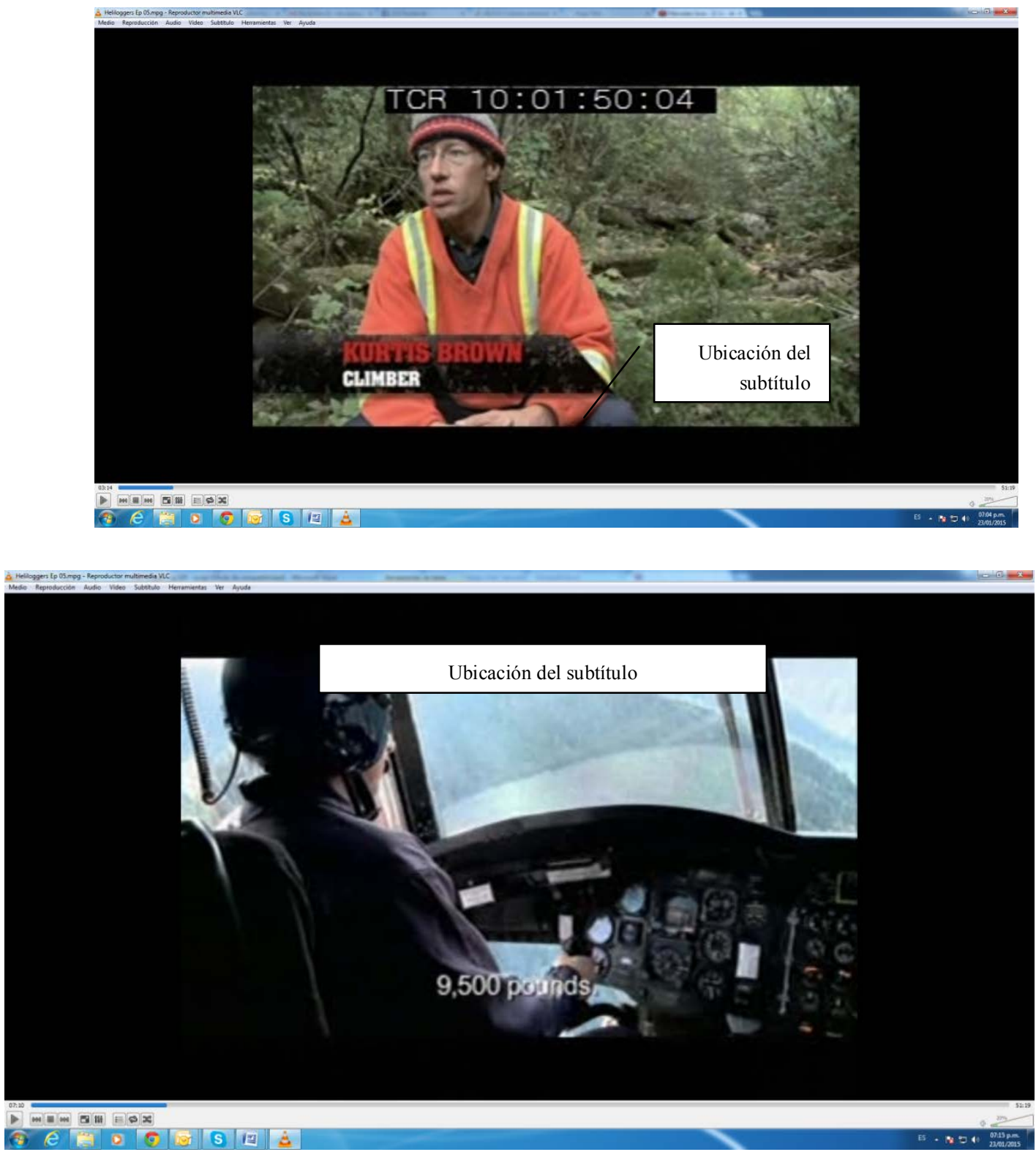


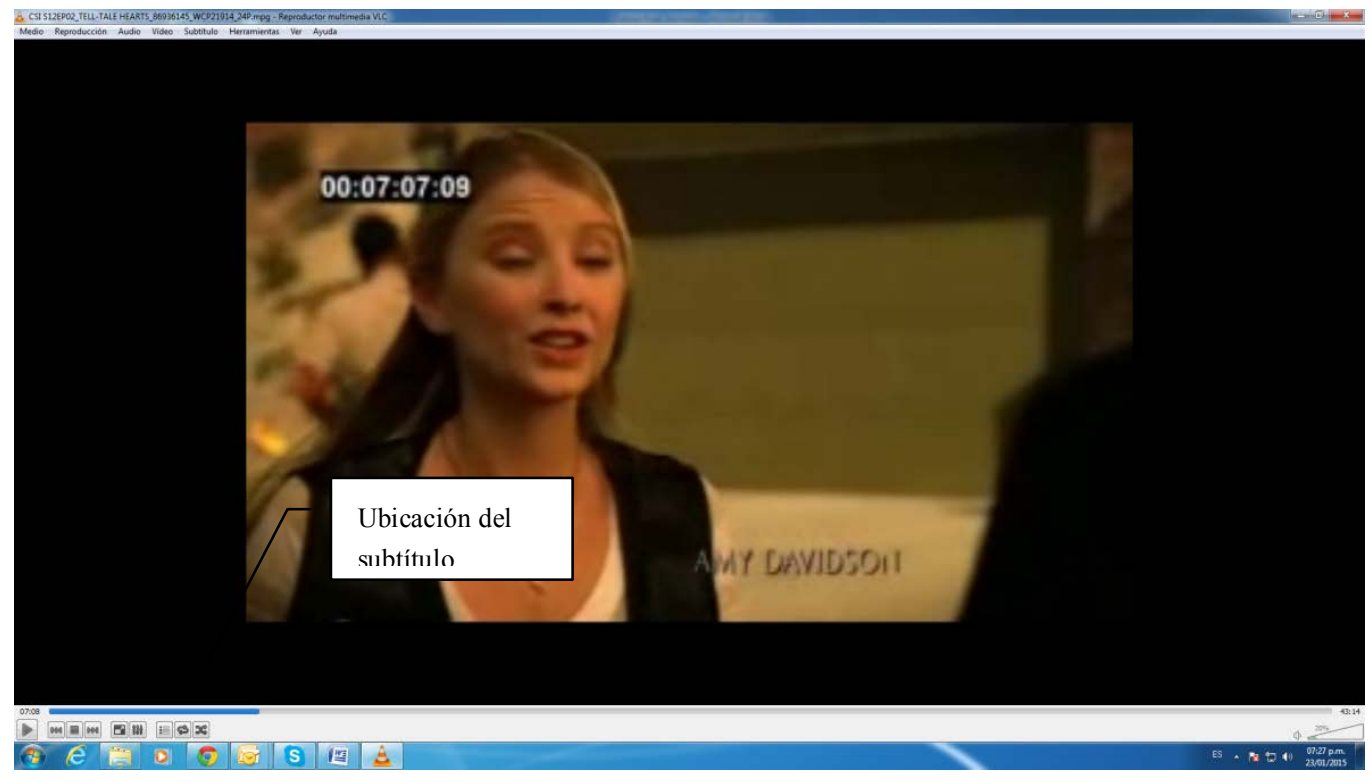

Reitero que si los subtítulos ocupan el extremo inferior opuesto al del cartel, su extensión debe reducirse a la mitad de los caracteres y, preferentemente, no tener más de una línea, ya que el lector necesita leer y aprehender ambos textos, el del subtítulo y el del gráfico, en la misma cantidad de segundos que le hubiese destinado a la lectura del primero. En cambio, si el gráfico o cartel aparece en la ubicación convencional, la del extremo inferior central, el subtítulo se desplaza hacia el extremo superior central. En esta circunstancia, también es aconsejable reducir la extensión a una línea para ocupar la menor cantidad de superficie posible en la pantalla. En las capturas de pantalla a continuación, vemos cómo podrían quedar los subtítulos (préstese atención a la alineación): 

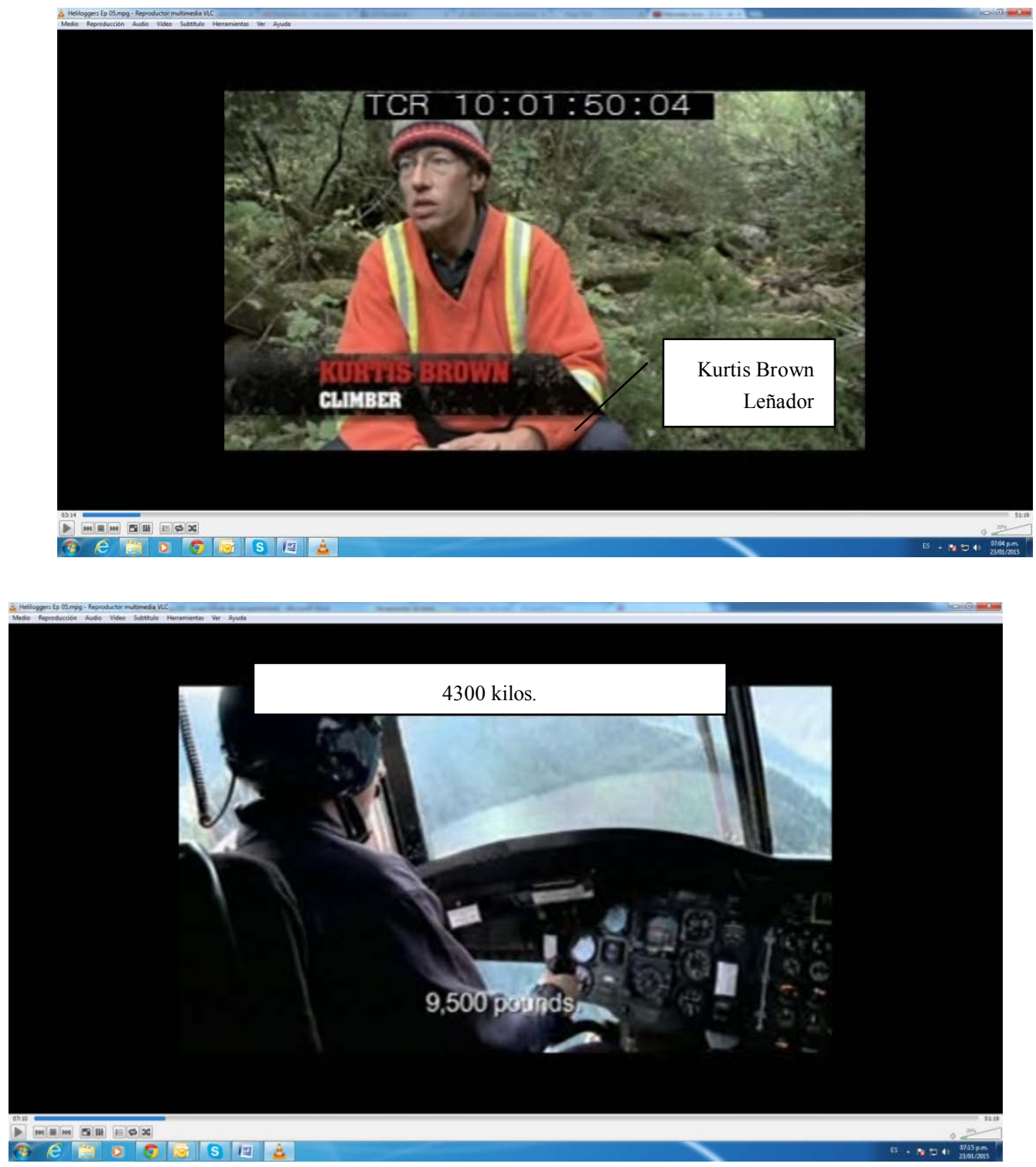


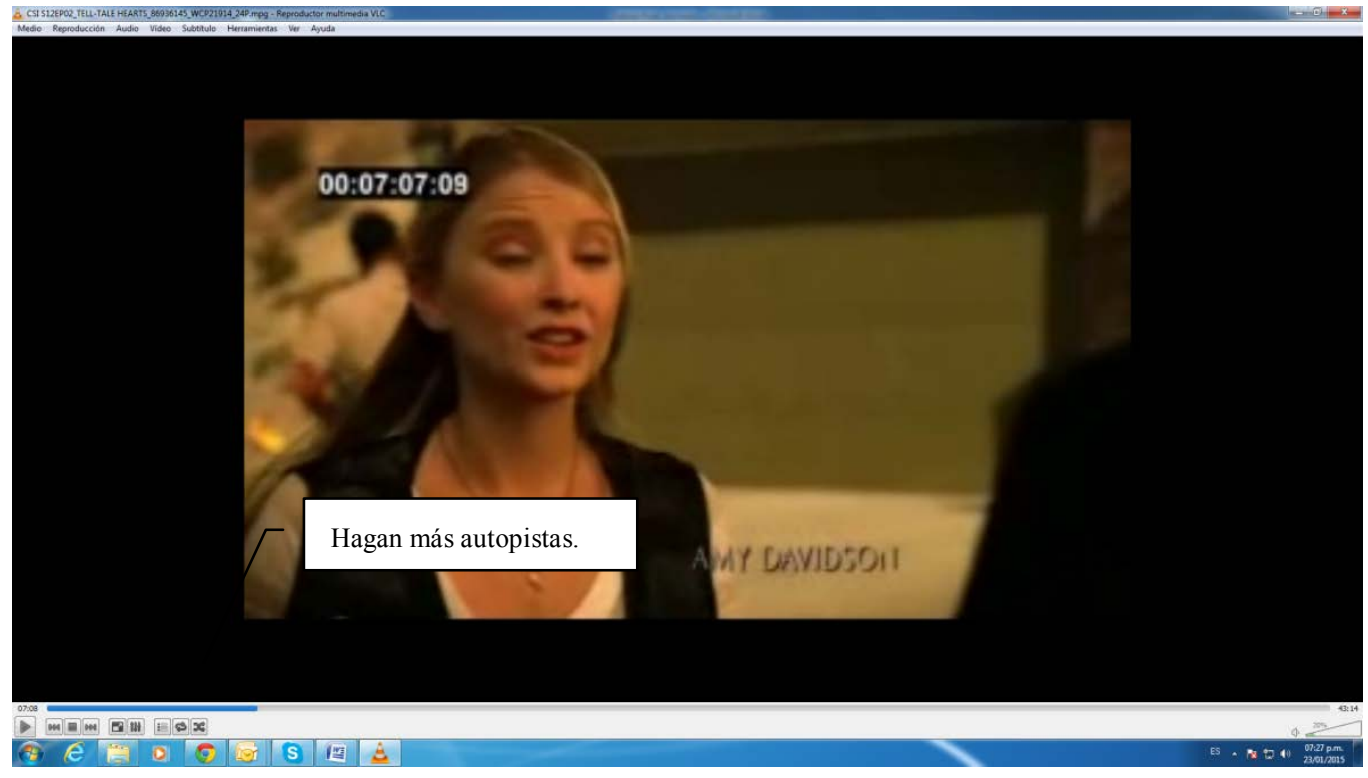

(En este último caso, se necesitó realizar una reducción considerable del texto, ya que el original en inglés decía: You could do with a couple more freeways, couldn't you?)

Las alteraciones en el posicionamiento de los subtítulos debieran ponerse en práctica solamente en situaciones extraordinarias para evitar la intervención excesiva del texto escrito sobre la imagen y no entorpecer la lectura del espectador, quien se desorienta en la búsqueda del objetivo visual al modificar la posición convencional. Una sugerencia práctica en relación con este tema: es importante que el subtítulo que se ha movido hacia la parte superior o uno de los extremos inferiores de la imagen conserve esta misma posición hasta completar la unidad sintáctica para no añadir al espectador un esfuerzo extra al de desplazar los ojos por la pantalla en una suerte de escaneo.

Veamos este ejemplo: 

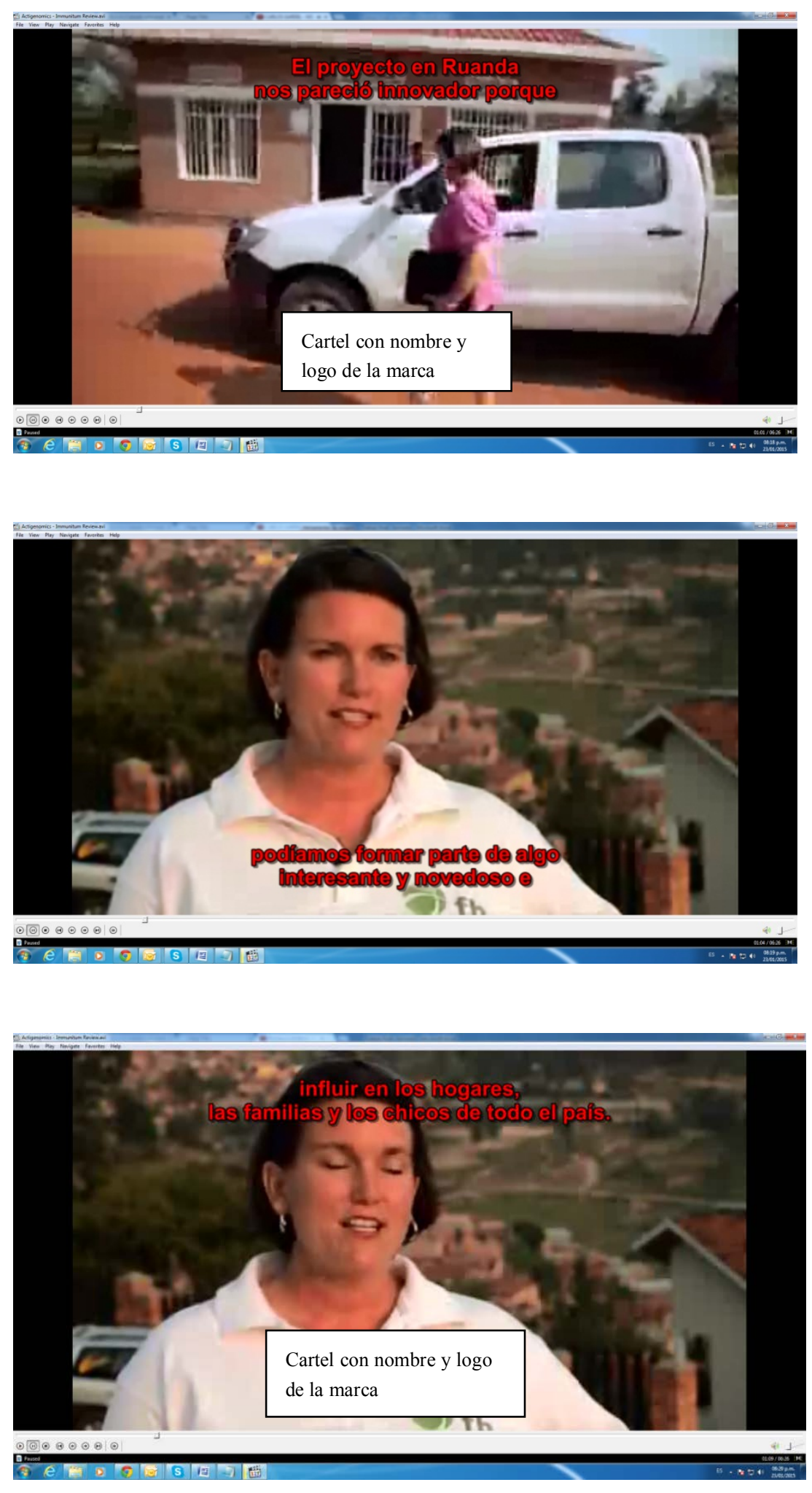

Lo correcto hubiese sido que todos los subtítulos permanecieran en la posición superior hasta completar la oración. 
Para concluir con los problemas técnico-pragmáticos que presenta el posicionamiento de los subtítulos, quisiera plantear una inquietud que me surge como espectadora de material subtitulado: si bien es cierto que hay gráficos que brindan información imprescindible para la comprensión del texto audiovisual, hay otros que podrían reubicarse en la etapa de edición del material. En el caso de los créditos, los de cierre pero principalmente los de apertura de un programa o filme, la inclusión de esta información por separado (los créditos sobre fondo negro que suelen verse al final) o en pasajes no dialogados facilitaría la tarea del subtitulador y mejoraría la experiencia del espectador.

Me gustaría regresar ahora al objetivo central de este trabajo para ahondar en su problemática y ofrecer nuevos puntos de vista. La extensión limitada de caracteres por línea trae como consecuencia, la mayoría de las veces, la disyuntiva más dramática del traductor de subtítulos, en especial del novato: si la reducción del texto original es inevitable, ¿por qué parámetros me rijo para decidir qué elementos conservar y cuáles descartar? Antes de explicar la utilidad que pudiera tener la teoría de la relevancia en la tarea del traductor a la hora de efectuar un recorte, me parece crucial dejar en claro que el subtítulo es una convención gráfica que debe ser interpretada como tal para no caer en la actitud fútil y simplista de traduttore, traditore. Esto vuelve a equiparar los subtítulos con el concepto de imagen que solemos tener en mente. Cuando alguien observa un cuadro, por ejemplo, sabe que lo que tiene delante de sus ojos es lo que el artista decidió rescatar de lo que ve, aun en el caso de que se haya basado en un modelo real; y también sabe que existen códigos de transposición, inherentes a la tarea del artista (la elección en la intensidad de los colores, la nitidez de los trazos, la perspectiva). De ahí que el observador, independientemente de que haya tenido contacto con el modelo original, no se sienta traicionado ante la obra plástica ni adopte una actitud suspicaz con respecto a la veracidad de la información que le brinda el artista. Esta es la paradoja que plantea el famoso cuadro de René Magritte, donde se ve una pipa y, al pie, la leyenda Ceci n'est pas une pipe (Esto 
no es una pipa): es obvio que lo que se observa es una ilustración, pero la convención del lenguaje pictórico indica que eso es una pipa porque, en términos generales, se consideran las imágenes de los objetos como los objetos en sí. En palabras de W. J. T. Mitchell, "este hábito hace que la leyenda 'esto no es una pipa' sea literalmente cierta, pero figurativamente falsa" ${ }^{44}$.

Los subtítulos deberían generar la misma percepción. Así como los espectadores decodifican naturalmente determinadas convenciones relacionadas con la grafía (el uso de mayúsculas en todas las letras de una palabra o la repetición de los signos de exclamación para indicar que el tono de voz del hablante se elevó; los símbolos o los puntos suspensivos que reemplazan los vocablos soeces), cuanto más firmemente se instale la noción de que la ocasional reducción del texto original se debe a una limitación técnica y que no afecta en absoluto los conceptos centrales de la obra original, mayor será el vínculo de confianza que se establezca entre la traducción y los espectadores. Ante una narración fílmica, el espectador desarrolla intuitivamente una doble actividad, cognitiva y racional. Por un lado, las facultades perceptivas y los saberes previos lo guían en la interpretación de las imágenes, pero, por otro, la lógica intelectual le recuerda que la transmisión de esas imágenes está atravesada por la existencia de un determinado modus operandi propio del cine. Para disfrutar y vivenciar lo que se está viendo, las actividades perceptivas deben imponerse a las racionales; el espectador tiene que aceptar las reglas de juego que le imponen los textos audiovisuales y dejarse llevar por los sentidos. En el caso de los textos subtitulados, una de las reglas debería ser considerar el subtítulo simplemente como una ayuda que se brinda para la comprensión general del texto y, como tal, otorgarle validez y no someterlo a inútiles análisis exhaustivos. Estos lineamientos van en consonancia con los conceptos de Saussure de arbitrariedad (las convenciones son arbitrarias por naturaleza) y de motivación (en este caso, la necesidad de entablar una relación de entendimiento con un código desconocido, la lengua extranjera). Cuando más claramente se ejemplifican estas nociones es en el visionado de materiales fílmicos provenientes de culturas muy disímiles de la

44 Mitchell, W.J.T. (1994), página 66. La traducción es de mi autoría. 
del espectador y hablados en un idioma que este desconoce por completo y con el que no puede establecer ningún parámetro de referencia. En esos casos, el espectador se ve imposibilitado de contraponer lo escrito con lo dicho; su actividad racional en relación con las competencias lingüísticas queda forzosamente anulada, y la actividad perceptiva, junto con el conocimiento y la aceptación de las convenciones propias de la traducción de textos audiovisuales, se adueñan del terreno y lo guían en la comprensión de la obra. Gunther Kress expresa este fenómeno de manera muy simpática:

"[...] en la semiótica de Saussure, si el objetivo es que me entiendan, debo lograrlo aprendiendo las normas sociales de uso de los recursos semióticos que los que me rodean conocen y ponen en práctica. Si no conozco las normas, estoy en problemas. ${ }^{45}$,

A mi entender, ya queda debidamente justificada la frecuente necesidad de efectuar recortes al texto original de un material audiovisual, y, a su vez, se dio por tierra con el preconcepto de que dichos recortes obligadamente acarrean la pérdida de nociones fundamentales de la narración fílmica. No obstante, queda pendiente el análisis del proceso a través del cual el traductor decide qué elementos son imprescindibles y cuáles pueden obviarse.

Si bien la teoría de la relevancia postulada por Dan Sperber y Deirdre Wilson tenía como objetivo la comunicación intralingüística y no la interlingüística, algunos de sus conceptos pueden aplicarse oportunamente a la traducción de subtítulos, ya que el foco de esta teoría está puesto en que las expectativas de cumplimiento de los enunciados, en relación con su relevancia dentro de un contexto determinado, resulten tan claras y predecibles que el receptor pueda arribar rápidamente y sin obstrucciones al significado pretendido por el emisor. El receptor procesa la información brindada por el emisor en busca de datos potencialmente relevantes dentro de la situación establecida; una vez que halla la presunción más relevante (óptimamente relevante, en la terminología de Sperber y

45 Kress, Gunther (2012), página 64. La traducción es de mi autoría. 
Wilson), deja de procesar. $Y$ no olvidemos que, en el armado y la lectura de subtítulos, la economía temporal y la eficacia son dos cualidades muy valoradas. En el caso de la comunicación interlingüística, la diferencia reside en que, en un diálogo entre dos personas, la intención del emisor siempre tiene como objetivo final al receptor; en cambio, cuando se trata de un texto traducido, el traductor, en su rol de intermediario, debe recrear la intención de ese emisor y transmitírsela al receptor.

La teoría de la relevancia, postulada por Dan Sperber y Deidre Wilson, es una profundización de uno de los conceptos más importantes de Paul Grice. Este concepto realza la función de la expresión y del reconocimiento de las intenciones del emisor en la mayoría de los actos de la comunicación humana. El modelo de Grice es básicamente inferencial y postula que el receptor debe decodificar la intención que desea transmitir el hablante a partir de evidencias suministradas por este último, las que no se limitan al plano lingüístico. La teoría de la relevancia se nutre también de otro de los conceptos de Grice, que sostiene que cualquier emisión genera en el receptor expectativas que lo guían al significado pretendido por el hablante. Grice describe estas expectativas dentro del marco de un principio de cooperación y de una serie de máximas que, en su opinión, deberían regir la conversación humana para que resulte precisa y eficaz. Este principio de cooperación propone que uno "haga que su contribución a la conversación sea, en cada momento, la requerida por el propósito o la dirección del intercambio comunicativo en el que está involucrado". En cuanto a las máximas, las más pertinentes en relación con el armado de subtítulos son:

- "Haga su contribución tan informativa como se requiera (de acuerdo con el propósito de la comunicación)" (máxima de cantidad)

- "Sea relevante" (máxima de relevancia)

- "Evite la oscuridad de expresión" (máxima de modo)

- "Evite la ambigüedad" (máxima de modo)

- "Sea breve" (máxima de modo) 


\section{- "Sea ordenado" (máxima de modo) $)^{46}$}

Para determinar qué es lo que se entiende como relevante ante la necesidad de efectuar un recorte, me gustaría detenerme particularmente en dos de los elementos de la teoría de Sperber y Wilson: la influencia de las implicancias contextuales y el afán por reducir al mínimo el esfuerzo de procesamiento de la información ${ }^{47}$. Sus propios autores definen la teoría de la relevancia como una teoría psicológica-cognitiva, ya que analiza la interpretación de los enunciados como un proceso cognitivo y organiza los recursos, también cognitivos, en relación con la potencial relevancia de la información que se transmite al receptor.

En su artículo "The Constraint of Relevance in Subtitling", Łukasz Bogucki sostiene que la meta del traductor de subtítulos no debería ser recuperar la mayor cantidad de información posible, sino concentrarse en las inferencias de llegada más fluida e inmediata al espectador ${ }^{48}$. Recordemos que, en un texto audiovisual, la información se desgrana a través de diversos canales, sonoros y visuales; por eso el traductor, cual jardinero, debe podar el texto escrito de la mayor cantidad posible de malezas, o suposiciones alternativas, para que las implicancias contextuales más relevantes se destaquen y ejerzan una influencia contundente en el proceso cognitivo del espectador a través de un mensaje conciso y fácil de aprehender. De acuerdo con la terminología empleada por Sperber y Wilson, "todo estímulo externo o representación interna que sirva como input de un proceso cognitivo podrá considerarse relevante para un sujeto en una ocasión determinada" ${ }^{49}$. La combinación de este dato, o input, con los saberes previos del espectador y la situación particular en la que se produce el intercambio da como resultado un efecto cognitivo que influye "positivamente" (otra vez según la

\footnotetext{
46 Las definiciones en español, tanto de las máximas como del principio de cooperación, se tomaron de la siguiente entrada del Centro Virtual Cervantes:

http://cvc.cervantes.es/ensenanza/biblioteca ele/diccio ele/diccionario/principiocooperacion $\dot{\mathrm{htm}}$

47 Sperber y Wilson comparten con Grice la noción de que las emisiones despiertan

expectativas de relevancia, pero no coinciden en varios otros aspectos: entre ellos, la existencia per se de la voluntad de cooperación entre el emisor y el receptor. De todas maneras, la idea central de la teoría de la relevancia es que las expectativas generadas por un enunciado sean lo más precisas y predecibles posible y guien al receptor hacia el significado pretendido por el hablante.

48 Bogucki, Eukasz, página 75

49 Sperber, D. y Wilson, D. (2004) página 239
} 
terminología de Sperber y Wilson) en la interpretación del receptor. Veamos el ejemplo de la captura de pantalla de la página 42. El parlamento original en inglés (You could do with a couple more freeways, couldn't you?) intenta ser irónico y burlón. Si se aislara esta oración de su contexto, la ironía solamente podría recuperarse en la traducción utilizando una estructura similar a la de la oración original en inglés (No sería mala idea que construyeran un par de autopistas más, ¿no te parece?), aunque esta sería sin duda una opción extensa y con una estructura gramatical demasiado compleja para un subtítulo que permanece no más de cuatro o cinco segundos en pantalla y debe compartir el tiempo de lectura con un gráfico que anuncia el nombre de la actriz. En cambio, en contexto, las implicancias derivadas de los momentos previos a esta escena -la reacción de la chica, quien harta de que el GPS fracase reiteradamente en indicarle el camino correcto, se lanza a toda velocidad hacia su destino a través de los médanos, y el comentario sarcástico de su compañero en cuanto ella desciende del vehículo sobre sus cualidades como conductora (¿Quién te enseñó a manejar?)—, más la expresión entre sonriente y fastidiada de la actriz, aportan la información suficiente para dejar en claro que el propósito de la escueta frase de tono imperativo (Hagan más autopistas) no es literal, sino que se trata de una broma. Lo único que rescata el subtítulo es lo que el espectador no podría de ningún modo inferir, o le resultaría muy trabajoso, hacerlo. Esto demuestra a su vez que la modalidad oracional no determina la fuerza ilocutiva, sino que la intencionalidad de lo que se dice se deduce principalmente en función del contexto. La gramática y el contexto aportan datos que se combinan para generar ese efecto cognitivo positivo del que hablaban Sperber y Wilson: "la fuerza ilocutiva no es una propiedad de las oraciones, sino de los enunciados insertos en un contexto" ${ }^{50}$.

Retomando las diferencias entre las teorías de Sperber y Wilson y las de Grice, al menos en lo referente al esfuerzo de procesamiento, cabe señalar que mientras que la teoría de la relevancia sugiere que a mayor cantidad de estímulos contextuales y menor esfuerzo de procesamiento, mayor es la relevancia que cobra la información, la máxima de Grice advierte: "No diga lo que crea que es

50 Leonetti, Manuel (2006) página 4 
falso". A continuación, un ejemplo que los mismos autores de la teoría ofrecen (ligeramente modificado por mí) y que ilustra con claridad por qué esa máxima no se ajustaría a los fines prácticos de la traducción de subtítulos en lo concerniente a la eficacia en la lectura y la rápida comprensión del texto en pantalla (es decir, un menor esfuerzo en el procesamiento de la información). Imaginen una escena en la que una persona detiene a otra por la calle y le pregunta la hora; aunque se visualizara en pantalla un reloj que marcara las 11.59 , el personaje seguramente contestaría algo así como "Son las 12", ya que, por un lado, estaría cumpliendo con las expectativas del personaje que le formuló la pregunta y, por otro, le estaría brindando una información más fácil de procesar, aunque no estrictamente fiel. Ahora tomemos un ejemplo concreto y real de la serie estadounidense "The Whitest Kids You Know". El personaje anuncia: Barbara is 22-year-old sophomore at State University ${ }^{51}$. Si el traductor se atuviera a la máxima de Grice citada anteriormente, el texto en castellano debería ser: Barbara es una estudiante de 22 años que está cursando el segundo año en una universidad estatal de Estados Unidos. Sin embargo, debido a las limitaciones técnicas espacio-temporales, Barbara es una estudiante universitaria de 22 años sería un subtítulo mucho más adecuado porque no omite ningún dato relevante y es más fácil de procesar que el anterior en tiempo que el texto permanece en pantalla ${ }^{52}$. No obstante, es necesario señalar que la teoría de la relevancia también indica que son las implicancias contextuales las que determinan la necesidad de brindar datos más precisos o datos más generales. Si la persona que pregunta la hora fuera la encargada de hacer detonar una bomba en un momento exacto, la respuesta correcta sí hubiera sido "11.59". En caso contrario, y dado que la teoría de la relevancia prioriza los procesos cognitivos que permiten arribar a la interpretación de enunciados, es el esfuerzo de procesamiento el que se configura como factor determinante.

\footnotetext{
51 La situación es la siguiente: el presentador de un programa televisivo anuncia a la próxima participante de un certamen, cuyo fin es hallar pareja. Además del dato de su ocupación y edad, comenta brevemente sobre cuáles son sus pasatiempos y preferencias. 52 El subtítulo se extiende desde el minuto 35'29'' hasta el 39'15'', menos de cuatro segundos.
} 
"El hablante que desee lograr un determinado rango de efectos contextuales debe asegurarse de que el oyente los recupere lo más fácilmente posible; es decir, el hablante debe cerciorarse de que lo que dice no expone al oyente a ningún esfuerzo de procesamiento innecesario. Esto favorece tanto el interés del hablante como el del oyente por dos razones: en primer lugar, lo que el hablante pretende es que se comprenda lo que dice $y$, si el esfuerzo de procesamiento por parte del oyente aumenta innecesariamente, también aumenta el riesgo de que se lo malinterprete; en segundo lugar, cualquier aumento en el esfuerzo de procesamiento resta importancia a la relevancia global de lo que se dice y podría llevarla a un nivel inferior al aceptable. ${ }^{53 "}$

Que el texto escrito exprese una parcialidad del texto original no implica necesariamente que lo que no se incluye sea irrelevante. Como expliqué en la primera parte de este trabajo, en un gran número de casos, muchos de los datos que deciden excluirse del subtítulo por la restricción espacial y temporal se transmiten a través de otros canales sensoriales, lo que ayuda al espectador a suplir la información omitida. Sin embargo, este modo de suministrar información promueve en los espectadores una licencia interpretativa que conlleva un riesgo: que su lectura sea distinta de la pretendida por el director o de la que el traductor imaginó que provocaría en el espectador. La lectura connotativa es inherente a cualquier expresión artística, y la imagen fílmica no es excepción: "[...] en una perspectiva estética el mensaje denotado puede aparecer como una suerte de estado adánico de la imagen ${ }^{54 "}$. Asimismo, en la traducción ese riesgo interpretativo se incrementa porque se producen, en una suerte de traspaso de mensajes, dos lecturas distintas, aunque encadenadas entre sí, de la intención del director: primero la del traductor $\mathrm{y}$, sobre esta base, la del espectador ${ }^{55}$.

\footnotetext{
3 Sperber, D. y Wilson, D. (1994), página 11. La traducción es de mi autoría.

54 Barthes, Roland (1964) página 8

55 De todas maneras, cabe subrayar que todo proceso de traducción siempre implica la selección de aquellas propiedades del texto original que sean más necesarias para producir el efecto que se pretende. Estas propiedades abarcan principalmente las semánticas, pero no
} 
En este proceso interpretativo, los textos audiovisuales provenientes de culturas ajenas a la idiosincrasia de los espectadores presentan un obstáculo extra, tanto para el traductor como para el público. En términos generales, el proceso de lectura de una imagen, en movimiento o estática, es el siguiente: primero, existe una etapa denotativa (un hombre eleva una de sus manos a la altura de los hombros y forma una "c" invertida con el índice y el pulgar); luego se continúa a una etapa convencional, en la que gravita el conocimiento que el receptor tenga de los códigos tradicionales de una cultura (la acción se sitúa en Buenos Aires, el hombre está sentado a la mesa de un bar, y el gesto va dirigido al mozo); y por último, se produce una etapa connotativa, o de significación intrínseca como la llama Aumont (el hombre le está pidiendo al mozo que le traiga un café corto, en pocillo). Cuando el creador de la obra original y los espectadores se desenvuelven dentro de los mismos códigos culturales, u otros similares, es altamente probable que el proceso de lectura se lleve a cabo exitosamente y tal como se pretendió desde un principio. Pero cuando esa significación intrínseca les es ajena a los espectadores de destino, el traductor, en su rol de mediador o primer intérprete, debe evaluar la situación y enfrentarse a la disyuntiva de decidir en qué momentos y hasta qué punto salvar la brecha entre el emisor y los receptores sin quitarle identidad a la cultura representada. Anna-Kazumi Stahl, en su artículo "Lecturas posibles del japonés", reflexiona sobre el motivo por el que, en los últimos tiempos, ha crecido ampliamente el número de escritores japoneses que publican y son éxitos de venta en lenguas occidentales. Para Stahl esto se debe a que estos autores, ya sea por la influencia recibida durante su educación en Estados Unidos o en países europeos, o por una actitud deliberada con el fin de lograr una penetración mayor en Occidente, homologan sus textos a la cultura dominante en el mercado, que es la de habla inglesa. En otras palabras, la obra de estos autores se vende profusamente en los países occidentales no por su exotismo, sino por sus puntos de contacto con la cultura receptora.

se descartan otros aspectos que puedan resultar distintivos, como los fonéticos. (Ver la noción de "uso interpretativo" en Escandell Vidal, 2000, página 3). 
"Vivimos hoy procesos de globalización que nos hacen cada vez más multilingües o conscientes de la presencia de otras lenguas y otras culturas, pero que, de cierta manera, también hacen cada vez más monolingüe lo que leemos y vemos ${ }^{56} . "$

\subsection{PROBLEMÁtICAS PARTICULARES DE GÉNEROS DETERMINADOS}

Para concluir esta sección, se abordará una problemática recurrente en la traducción con formato de subtítulos de tipos textuales audiovisuales como los documentales con testimonios espontáneos, los programas de entrevistas o los reality shows: la necesidad de establecer la legibilidad del texto mediante el reordenamiento de estructuras sintácticas. En las páginas anteriores se explicó que las probabilidades de lograr una comprensión adecuada del mensaje en pantalla aumentan cuanto más sencillo resulta aprehender lo que se lee. En este sentido, una sintaxis ordenada contribuye a reducir el esfuerzo de procesamiento, lo que le otorga una mayor relevancia a la información que se recibe.

En su artículo "La pretendida oralidad de los textos audiovisuales y sus implicaciones en la traducción", Frederic Chaume y Rosa Agost analizan el género particular de los diálogos de ficción. En un texto audiovisual de tono narrativo, los actores repiten un texto escrito, que fue previamente redactado para ser dicho de manera tal que resulte verosímil. Su oralidad no es espontánea, sino prefabricada. Por eso, independientemente de que la redacción intente copiar el registro oral adoptando sus particularidades (oraciones breves de sintaxis poco compleja, vocabulario informal y de aplicación corriente, uso de la elipsis, frases inconclusas, repeticiones, reformulaciones), no deja de tratarse de un texto sopesado y elaborado.

Cuando la tarea consiste en armar subtítulos para un material audiovisual que incluye entrevistas o testimonios en vivo, el traductor se ve en la obligación de acomodar el caos típico de estos parlamentos espontáneos. En una elocución

56 Stahl, Anna-Kazumi (2012) página 178 
verdaderamente natural —y no una mímesis de la oralidad_-, el hablante titubea, interrumpe una frase para continuar con otra diferente, repite innecesariamente palabras o conceptos, comete digresiones y redundancias, no siempre desarrolla su discurso de manera congruente y rara vez respeta el orden canónico de las oraciones. Una observación: los diálogos en los programas clasificados como reality shows no son estrictamente espontáneos, ya que estos formatos televisivos se rigen, en su mayoría, por pautas sobre cómo deben desenvolverse la trama y los parlamentos. De todos modos, reina en los intercambios orales el desorden sintáctico propio de un texto que no ha sido previamente redactado.

En el plano de la lingüística, esta necesidad de ofrecer a los espectadores un texto simple de entender se apoya no solo en la noción del mínimo esfuerzo de procesamiento de la teoría de la relevancia, sino también en la máxima comunicacional de Grice que impone "ser ordenados" para que el mensaje llegue al receptor de la manera más clara y eficaz posible. Por otro lado, en términos cinematográficos, es fundamental que el traductor sincronice las pausas propias de las estructuras sintácticas con los intervalos en el material fílmico, lo que hace más claro el orden de la secuencia narrativa y facilita el procesamiento de la información. (Los programas profesionales para la inserción de subtítulos trabajan sobre la base de fotogramas; eso permite establecer con exactitud en qué instante el texto debe aparecer o desaparecer de la pantalla y sincronizarlos con la emisión de los parlamentos y los cambios de toma o escena. De esta manera, el traductor se asegura de que el subtítulo no se visualice antes de que comience a pronunciarse el parlamento ni deje de leerse después de que finaliza). En el lenguaje audiovisual, los intervalos, saltos o jump cuts son recursos estilísticos utilizados para expresar el transcurso del tiempo, el paso de una situación a otra, el cambio en el foco de la acción, entre otras cosas; en cambio, en la redacción de subtítulos, las herramientas que ayudan a que el espectador ordene su actividad mental y efectúe una lectura eficaz del texto en pantalla son los cortes sintácticos. Esto no implica que cada subtítulo deba contener indefectiblemente una estructura oracional completa; la oración puede continuarse en los subtítulos siguientes. Sin embargo, cuanto más breve y ordenada sea la unidad sintáctica, más sencillo será 
para el espectador captar el sentido principal y relacionarlo con la imagen que se le ofrece.

Veamos los ejemplos de la página 43.

(primer subtítulo)

El proyecto en Ruanda

nos pareció innovador porque

\section{(segundo subtítulo)}

podíamos formar parte de algo

interesante y novedoso e

\section{(tercer subtítulo)}

influir en los hogares,

las familias y los chicos de todo el país.

Estos subtítulos presentan más de un error. Además del posicionamiento inadecuado en la pantalla, la estructura oracional es innecesariamente extensa y los cortes no respetan una sintaxis lógica. Si nos atenemos al consejo brindado por Agost y Chaume en el artículo antes mencionado - "evitar la segmentación del enunciado en sucesivos fragmentos, lo que conferiría un cierto aislamiento y una expresión discontinua" ${ }^{57}$-, el texto debería haberse divido en, al menos, dos oraciones, en vez de expresar todo el concepto en una sola oración larga.

(primer subtítulo)

El proyecto en Ruanda

nos pareció innovador.

(segundo subtítulo)

Podíamos formar parte de algo

57 Agost, Rosa y Chaume, Frederic (2001) página 87 
interesante y novedoso e

\section{(tercer subtítulo)}

influir en los hogares,

las familias y los chicos de todo el país.

Por otra parte, en cuanto a los cortes intraoracionales, quiero citar dos fragmentos de un texto del profesor Jorge Díaz Cintas:

"Una manera de reforzar la cohesión y la coherencia del producto se consigue con una buena segmentación de los subtítulos. El traductor es responsable de producir unos subtítulos que sean comprendidos con facilidad en el poco tiempo en que aparecen en pantalla y en su relativo aislamiento, por lo que cada subtítulo debería ser una unidad sintáctica y lógica en sí misma. Hay que asegurar una estructura individual que no dé lugar a dudas en cuanto a su significado y, en la medida de lo posible, estructurarlo sintácticamente de tal modo que se identifique con una oración completa."

"La división de la frase debe ser lo más lógica posible, de modo que deje entrever la interdependencia sintáctica de los diversos elementos que la componen y mantenga las unidades superiores sin fragmentar." ${ }^{\text {5 }}$

Para lograr esto, Díaz Cintas ofrece algunos consejos prácticos (obviamente, siempre que esto sea posible y que no afecte otros aspectos fundamentales de la elocución):

$\checkmark$ en el caso de que el subtítulo contenga dos oraciones, tratar que a cada una le corresponda una línea distinta;

58 Díaz Cintas, Jorge (2003) páginas 218 y 219 


\begin{tabular}{|l|l|}
\hline NO & Sí \\
\hline Me voy. Te & Me voy. \\
aviso cuando llegue. & Te aviso cuando llegue. \\
\hline
\end{tabular}

$\checkmark$ cuando la oración es compuesta, destinar una línea o un subtítulo a la proposición principal y otra u otro a la subordinada;

\begin{tabular}{|l|l|}
\hline NO & Sí \\
\hline $\begin{array}{l}\text { Si le pegas, no vuelvo } \\
\text { a hablarte. }\end{array}$ & $\begin{array}{l}\text { Si le pegas, } \\
\text { no vuelvo a hablarte. }\end{array}$ \\
& $* * *$ \\
$\begin{array}{l}\text { Cuando sepas } \\
\text { los resultados, ven }\end{array}$ & $\begin{array}{l}\text { Cuando sepas } \\
\text { los resultados, }\end{array}$ \\
a contarme enseguida. & ven a contarme enseguida. \\
\hline
\end{tabular}

$\checkmark$ dividir las oraciones por la conjunción o el pronombre que separa la subordinada de la principal;

\begin{tabular}{|c|c|}
\hline NO & Sí \\
\hline Me aseguró que & Me aseguró \\
\hline no lo había visto. & que no lo había visto. \\
\hline$* * *$ & $* * *$ \\
\hline El senador estaba al tanto pero & El senador estaba al tanto \\
\hline $\begin{array}{l}\text { ocultó la información porque lo } \\
\text { comprometía. }\end{array}$ & $\begin{array}{l}\text { pero ocultó la información } \\
\text { porque lo comprometía. }\end{array}$ \\
\hline
\end{tabular}


$\checkmark$ dividir las oraciones respetando las unidades sintácticas básicas (sujeto y predicado; núcleo verbal y objetos directos o indirectos; proposición principal y circunstanciales; artículo y sustantivo; proposiciones coordinadas);

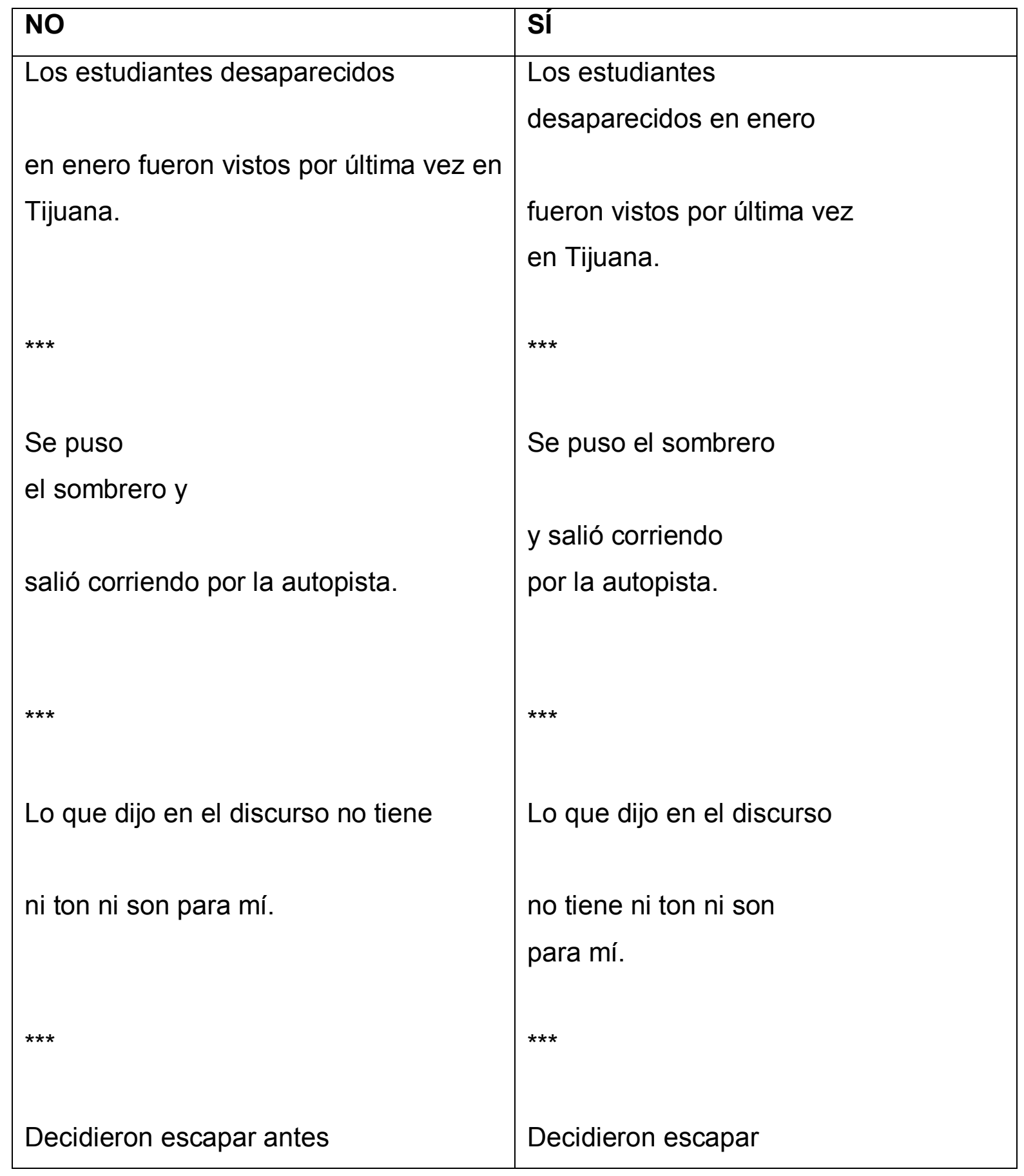


$\checkmark$ siempre y cuando no se altere el sentido del texto, la sincronía con las imágenes o el énfasis pretendido, se prefieren las estructuras canónicas.

\begin{tabular}{|l|l|}
\hline NO & Sí \\
\hline $\begin{array}{l}\text { Es una tarde, } \\
\text { como diría mi abuela, }\end{array}$ & $\begin{array}{l}\text { Como diría mi abuela, } \\
\text { es una tarde de aquellas. }\end{array}$ \\
de aquellas. & \\
\hline
\end{tabular}

Teniendo estas sugerencias en cuenta, la versión más correcta de los subtítulos de la página 43 sería:

\section{(primer subtítulo)}

El proyecto en Ruanda

nos pareció innovador.

\section{(segundo subtítulo)}

Podíamos formar parte

de algo interesante y novedoso

(tercer subtítulo)

e influir en los hogares,

las familias y los chicos de todo el país.

\section{ESTUDIO DE CASOS}


Tal como aclaré en la introducción del trabajo, el corpus seleccionado con el fin de ejemplificar mediante situaciones concretas los conceptos hasta aquí elaborados se restringe a largometrajes o series televisivas y dibujos animados, no solo porque este material resulta más atractivo, sino por el peso equitativo que ejercen sobre la trama narrativa los diálogos (el texto modificable) y las imágenes (el texto inalterable) y por la interacción generadora de significado que se produce entre ambos elementos. Dentro de este espectro, decidí inclinarme por textos audiovisuales de tono humorístico o destinados al público infantil, ya que en estos géneros se exploran más al límite las posibilidades creativas en el uso del lenguaje.

Los dos primeros ejemplos corresponden al cuarto episodio de la sexta temporada de la serie de humor estadounidense The Big Bang Theory, "The ReEntry Minimisation". En uno, se observa claramente cómo la presencia de determinadas imágenes estáticas plantea una limitación en la traducción del diálogo original y se analizará la posibilidad de optimizar los aportes de los sistemas visuales convergentes para que el subtítulo resulte claro, dinámico, y cumpla con eficacia el propósito primordial de la acción, que es crear una situación de humor disparatado. En el otro ejemplo, se presenta una situación potencialmente controvertida para el traductor, cuya resolución se simplifica al aprovechar la información vertida por el sistema de imágenes en movimiento.

\section{a. CUANDO LA IMAGEN PLANTEA UN OBSTÁCULO}

La secuencia que se estudiará se extiende desde el minuto 3:37 hasta el 7:26. La situación es la siguiente: cuatro de los protagonistas de la serie están jugando al Pictionary ${ }^{59}$, y el humor se genera a partir de los dibujos y las interpretaciones que los personajes hacen de ellos. El hecho de que las imágenes que se van delineando en las pizarras sean inalterables y que los juegos de palabras que se crean a partir de ellas constituyan el elemento principal para el

\footnotetext{
59 Juego que consiste en adivinar una palabra a través de un dibujo. Gana el jugador o el equipo que más palabras o frases adivine.
} 
desarrollo del paso de comedia representan la problemática central de la traducción del fragmento.

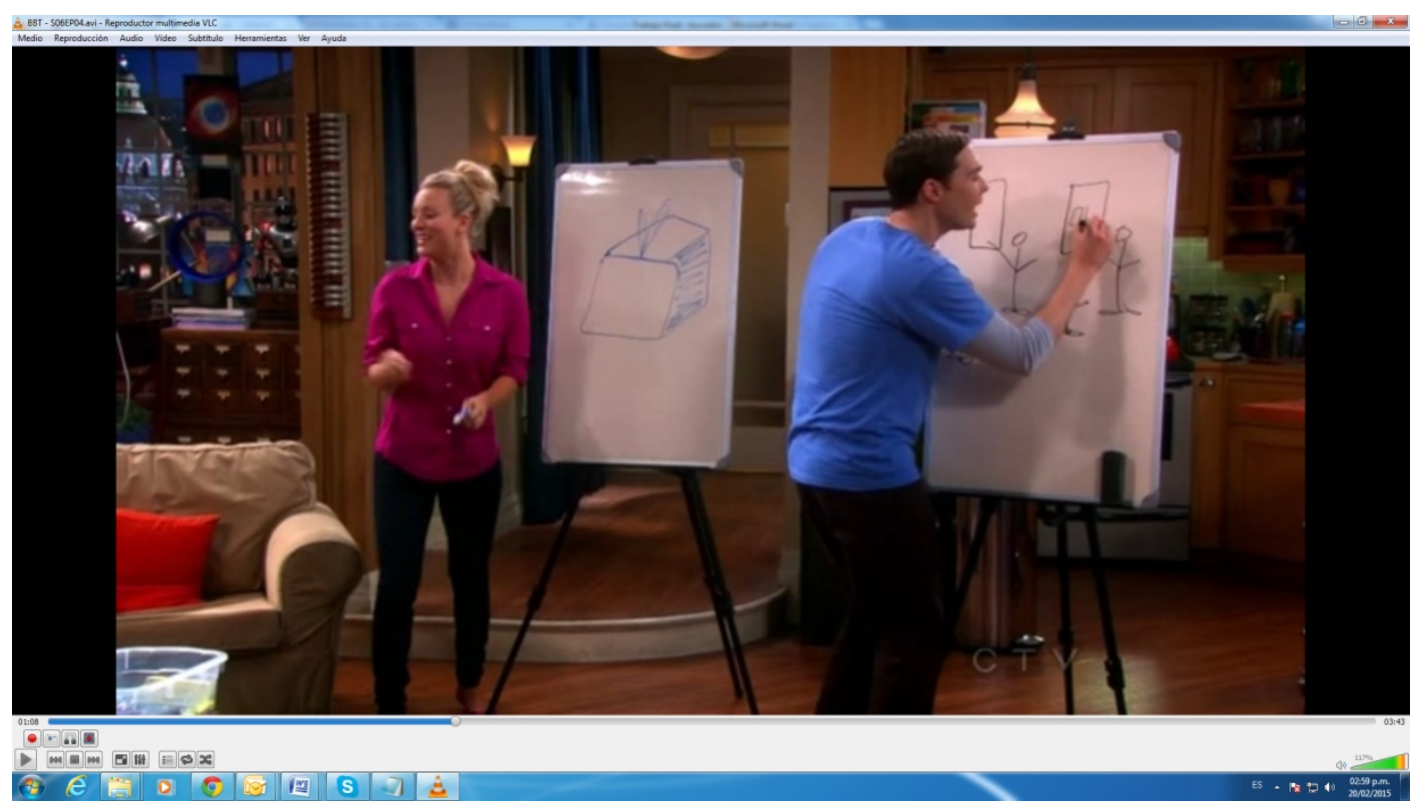

Foto 1

La primera palabra que tanto Penny como Sheldon deben dibujar para que sus compañeros adivinen (foto 1) no representa ningún inconveniente para el traductor, ya que las palabras "presente" y "present" son polisémicas en ambos idiomas y cuentan, en ambos idiomas también, con los dos significados involucrados: "presente/present" como definición temporal, en oposición al pasado o al futuro, y "presente/present" como sinónimo de "regalo" u "obsequio". En la versión subtitulada de este episodio, la imagen complementará a la perfección el texto en pantalla.

\begin{tabular}{|l|l|}
\hline TEXTO ORIGINAL & TEXTO TRADUCIDO \\
\hline AMY: A gift? Present! & AMY: ¿Regalo? ¡Presente! \\
PENNY: Present! Yeah! & PENNY: ¡Sí! ¡Presente! \\
SHELDON: Oh... Leonard. Now, & SHELDON: Pero, Leonard. \\
\hline
\end{tabular}




\begin{tabular}{|c|c|}
\hline get that? & ¿Cómo no te diste cuenta? \\
\hline $\begin{array}{l}\text { LEONARD: In what universe is } \\
\text { that a present? }\end{array}$ & $\begin{array}{l}\text { LEONARD: ¿En qué universo eso } \\
\text { es un presente? }\end{array}$ \\
\hline $\begin{array}{l}\text { SHELDON: It's not a present, it's } \\
\text { the present. Look. } \\
\text { There's you and me. It's Penny } \\
\text { and Amy. We're playing Pictionary. In } \\
\text { the present. }\end{array}$ & $\begin{array}{l}\text { SHELDON: No es un presente; es } \\
\text { el presente. Mira. } \\
\text { Estos somos tú y yo. Penny y } \\
\text { Amy. Estamos jugando Pictionary. En el } \\
\text { presente. }\end{array}$ \\
\hline
\end{tabular}

La segunda palabra que los participantes del juego deben adivinar tampoco representa una dificultad para el traductor; sin embargo, vale la pena incluirla en el análisis, ya que constituye un ejemplo interesante de cómo el entorno y los conocimientos previos condicionan la lectura que un espectador haga de una imagen. ${ }^{60}$

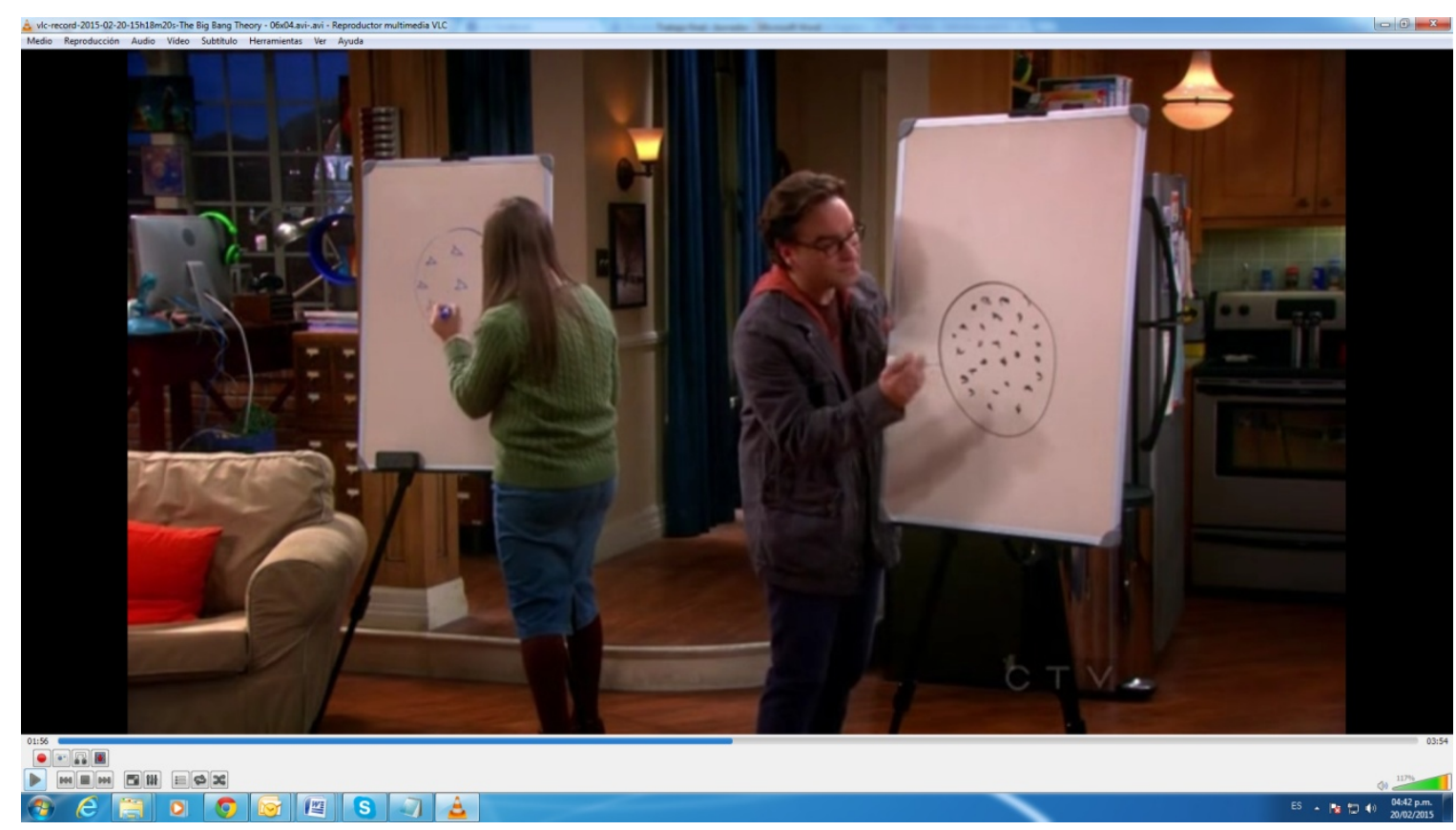

Foto 2

60 En relación con las posibilidades interpretativas, la Gestalt propone el término "percepción multiestable" para hacer referencia a las interpretaciones dobles, triples o múltiples que provocan determinadas imágenes ambiguas, como el cubo de Necker, el vaso de Rubin, la cruz doble, el pato/conejo, entre varias otras. 
Si bien lo que Amy y Leonard dibujan no son imágenes prototípicamente ambiguas, y a pesar de ser bastantes parecidas entre sí (foto 2), es llamativo observar lo disímil de las interpretaciones propuestas por Penny (una camarera en un local de comidas) y por Sheldon (un físico teórico dedicado a la investigación). La divergencia se explica dado que las imágenes se analizan a través del filtro que impone la mirada de cada espectador, quien inevitablemente sacará conjeturas y establecerá relaciones autorreferenciales, condicionadas por sus saberes e historia personal. Repito lo que dije anteriormente: la mirada nunca es inocente. "Los ojos físicos ven todos lo mismo; sin embargo... los ojos mentales reflejan sus propias individualidades." ${ }^{\text {11 }}$ Por eso, donde Penny ve una galletita con chispas de chocolate, Sheldon ve un plasma de quarks-gluones o una refutación al modelo Lambda-CDM del universo.

Por último, la palabra, "polish" (fotos 3 y 4 ) extiende las posibilidades de la ambigüedad interpretativa hasta los límites de la incongruencia (en el terreno del humor, la "máxima" es no cumplir al menos con una de las reglas de Grice, en especial las que promulgan: sea relevante; evite la oscuridad de expresión; evite la ambigüedad) y, esta vez, sí se le plantea al traductor un problema con distintas aristas.

61 Leys, Ruth, en Mitchell, W.J.T. (1994), página 51. La traducción es de mi autoría. 


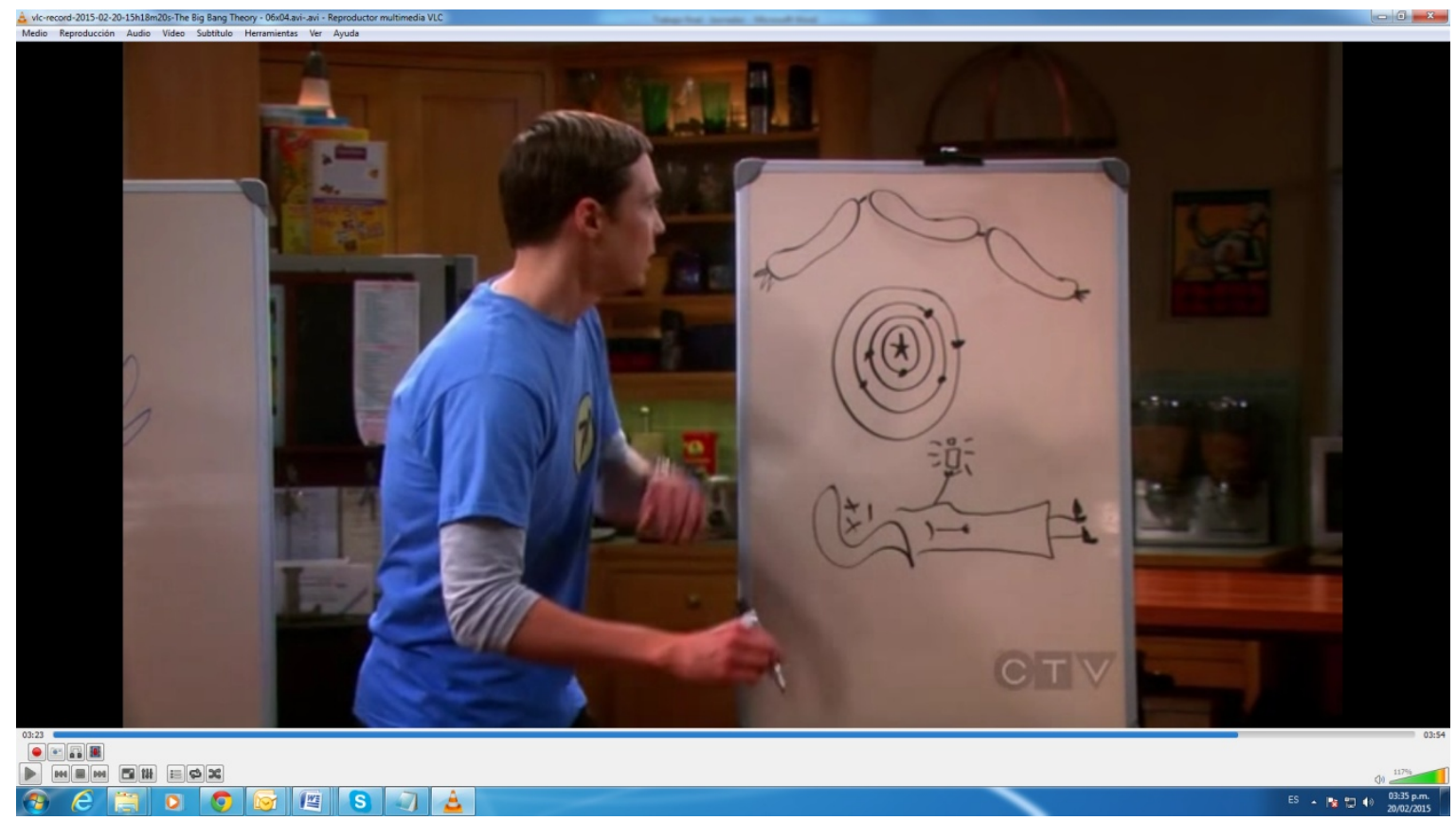

Foto 3

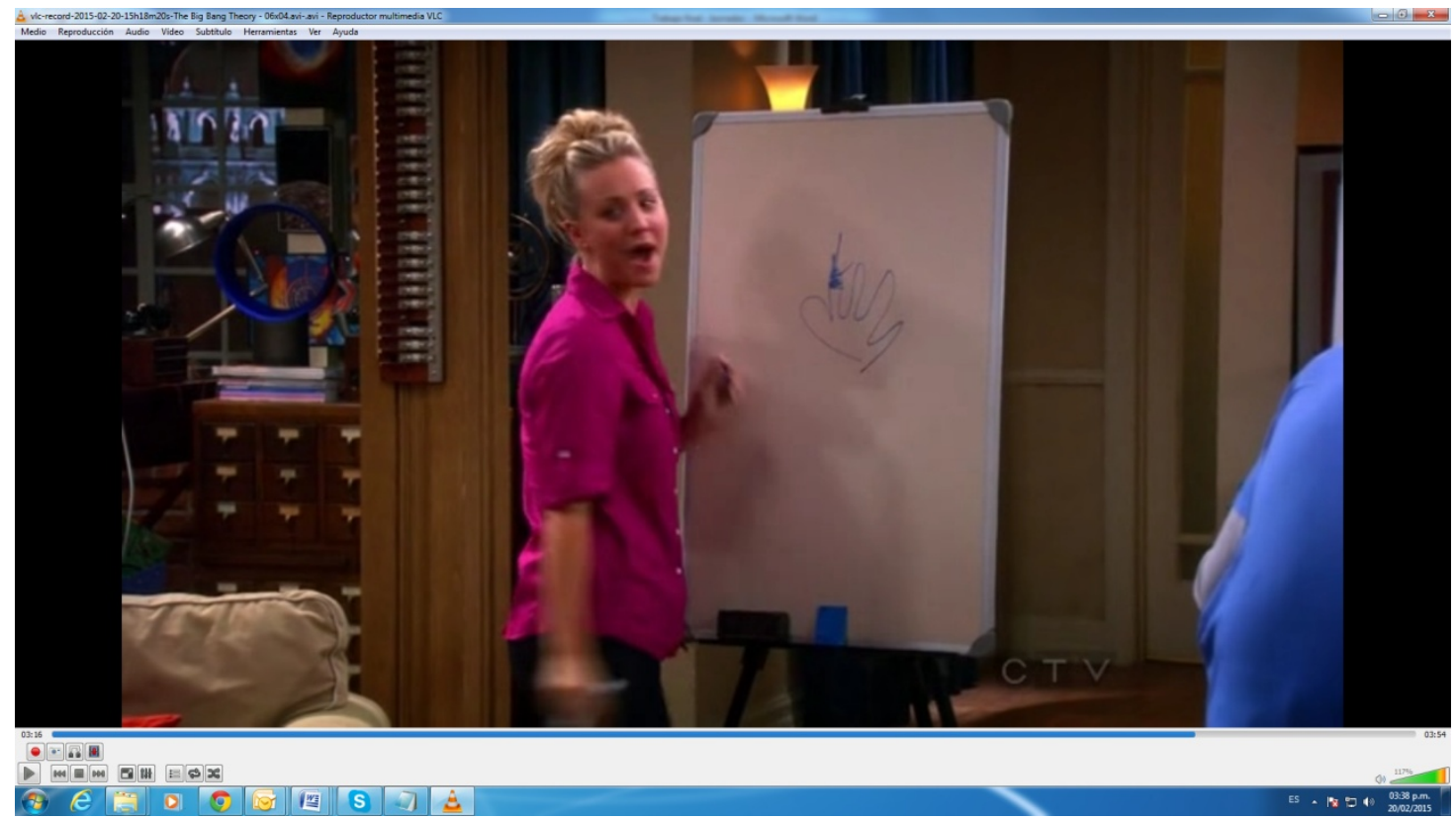

Foto 4

Analicemos estos problemas:

a) la palabra "polish" es ampliamente polisémica (puede aplicarse como sustantivo o como verbo, con la idea de 'cera', 'betún' o 'laca', o de 'dar lustre o brillo a algo' 
respectivamente; unida al término "nail" significa 'esmalte para uñas'; y, escrita con mayúscula, hace referencia a una nacionalidad o a un idioma, la polaca o el polaco, respectivamente) mientras que "polaca/o" o "esmalte/laca" no lo son;

b) el personaje de Sheldon realiza más de un esfuerzo para que Leonard resuelva el enigma; los tres dibujos que traza en los sucesivos e infructuosos intentos tienen, según su opinión, un elemento en común, que, a su vez, se relaciona con la palabra que origina el dibujo de Penny;

c) con el fin de invalidar el triunfo de Penny, Sheldon argumenta que la palabra en cuestión no era "polish" (lustre, lustrar, esmalte, etcétera), sino su homófono "Polish" (polaca o polaco); esta diferenciación semántica creada por el cambio de la inicial minúscula por otra mayúscula es inexistente en la lengua castellana.

En este caso, los canales a través de los cuales los espectadores que no son angloparlantes reciben la información (el texto de los subtítulos y las ilustraciones) no se complementan $y$, si el texto original se tradujera literalmente sin realizar ninguna modificación, resultaría incongruente y para nada gracioso. Las imágenes estáticas -es decir, los dibujos-, por su preponderancia en la situación (el juego se basa exclusivamente en la interpretación de las imágenes) y por su inalterabilidad, cargan con todo el peso de la información. El diálogo pasa a ser entonces un elemento "alterable", de segundo orden, y son las palabras las que deberán adecuarse a lo que dicten las imágenes.

Los alumnos de la cátedra de Traducción Audiovisual de la Universidad del Museo Social Argentino intentaron reunir la información proporcionada por los distintos sistemas y reelaboraron el texto respetando tanto los dibujos en pantalla como el espíritu del guión (las pistas de Sheldon siempre estaban relacionadas con temas estrictamente científicos, muy alejados de la palabra que su compañero debía adivinar). La versión subtitulada en español que se emitió por televisión hizo total caso omiso a este desafío y brindó una traducción prácticamente literal, lo que resultó en una situación sinsentido y en absoluto cómica.

\begin{tabular}{|l|l|}
\hline TEXTO ORIGINAL & VERSIÓN EMITIDA POR TELEVISIÓN \\
\hline PENNY: All right, that's enough. & PENNY: Muy bien. Suficiente. \\
\hline
\end{tabular}




\begin{tabular}{|c|c|}
\hline AMY: Uh, hand...Uh, nail... Polish? & AMY: Mano... uña... ¿pinturita? \\
\hline PENNY: Yep! & PENNY: ¡Sí! \\
\hline $\begin{array}{l}\text { SHELDON: Wait, no, no! No! The word } \\
\text { is "Polish." See, look. Polish sausage. } \\
\text { And the model of the solar system } \\
\text { developed by Nicolaus Copernicus, a } \\
\text { Polish astronomer. And then, finally, if } \\
\text { that wasn't enough --which it should've } \\
\text { been-- this is Madame Curie } \\
\text { killing herself by discovering radium, } \\
\text { who, although she was } \\
\text { a naturalized French citizen, } \\
\text { was Polish by birth! } \\
\text { PENNY: Excuse me, the word is } \\
\text { "polish." See? Small "P." }\end{array}$ & $\begin{array}{l}\text { SHELDON: Momento, ¡no, no, no! La } \\
\text { palabra es "polaca". Mira. Salchichas } \\
\text { polacas. Y el modelo del sistema solar } \\
\text { desarrollado por Nicolás Copérnico, de } \\
\text { nacionalidad polaca. Y finalmente, } \\
\text { como si fuera poco, aunque no debería } \\
\text { haberlo sido, aquí está Madame Curie, } \\
\text { quien se suicidó por haber descubierto } \\
\text { el radio y, aunque nacionalizada } \\
\text { francesa, jera polaca de nacimiento! } \\
\text { PENNY: Perdón, la palabra es } \\
\text { "pinturita". La de las uñas. }\end{array}$ \\
\hline
\end{tabular}

Desde ya, esta versión no cumple en absoluto con la función comunicativa del texto al no incorporar el recurso estilístico más importante de la escena: el juego de palabras con los distintos significados de la palabra "polish" (de acuerdo con la clasificación de Jakobson, se trataría de la función poética o estética del texto).

Comparemos esta traducción con las soluciones propuestas por los alumnos. La consigna era traducir el fragmento realizando las modificaciones necesarias solamente las necesarias- para que el episodio en español tuviera en los espectadores hispanoparlantes el mismo efecto que el original en inglés en los angloparlantes; con el propósito de no restringir su creatividad, no se exigió a los alumnos que ajustaran el texto a una determinada cantidad de caracteres. Los cambios efectuados están marcados en rojo:

\begin{tabular}{|l|l|}
\hline TEXTO ORIGINAL & PROPUESTA 1 \\
\hline PENNY: All right, that's enough. & PENNY: Bueno, ya está bien. \\
AMY: Uh, hand...Uh, nail... Polish? & AMY: Mano, uña, ¿manicuría? \\
PENNY: Yep! & PENNY: ¡Sí! \\
\hline
\end{tabular}


SHELDON: Wait, no, no! No! The word is "Polish." See, look. Polish sausage. And the model of the solar system developed by Nicolaus Copernicus, a Polish astronomer. And then, finally, if that wasn't enough --which it should've been-- this is Madame Curie killing herself by discovering radium, who, although she was a naturalized French citizen, was Polish by birth!

PENNY: Excuse me, the word is "polish." See? Small "P."
SHELDON: ¡Esperen! No, no. ¡No! ¿Cómo no adivinaste?

Todo lleva a Madam Curie. Ella amaba las salchichas. Y admiraba el modelo del sistema solar desarrollado por el astrónomo Nicolás Copérnico. Y finalmente, por si todavía no adivinabas, algo que deberías haber hecho, acá está Madame Curie, iquien se suicidó por descubrir el radio, que, por si no lo ves, sostiene en la mano!

PENNY: No es "Mme. Curie". ¿Ves? Es "mani-curía".

\section{TEXTO ORIGINAL}

PENNY: All right, that's enough.

AMY: Uh, hand...Uh, nail... Polish?

PENNY: Yep!

SHELDON: Wait, no, no! No! The word is "Polish." See, look. Polish sausage. And the model of the solar system developed by Nicolaus Copernicus, a Polish astronomer. And then, finally, if that wasn't enough --which it should've been-- this is Madame Curie killing herself by discovering radium, who, although she was

a naturalized French citizen, was Polish by birth!

PENNY: Excuse me, the word is "polish." See? Small "P."

\section{PROPUESTA 2}

PENNY: Me cansé.

AMY: Mano... uña... ¿laca?

PENNY: ¡Sí!

SHELDON: No, esperen, no, no. ¡La palabra es "po-laca"! Miren. Salchichas "polacas". El modelo del sistema solar desarrollado por Nicolás Copérnico, de nacionalidad "polaca". Y, finalmente, si con esto no bastara, aunque debería haberlo hecho, esta es Marie Curie, quien se suicidó por haber inventado el radio y, a pesar de que se naturalizó como francesa, jera "polaca" de nacimiento!

PENNY: Disculpa, la palabra es "laca". ¿Ves? Sin el "po".

\begin{tabular}{|l|l|}
\hline TEXTO ORIGINAL & PROPUESTA 3 \\
\hline PENNY: All right, that's enough. & PENNY: Muy bien. Es suficiente. \\
\hline
\end{tabular}




\begin{tabular}{|c|c|}
\hline AMY: Uh, hand...Uh, nail... Polish? & AMY: Mano... Uña... esmalte... ¿laca? \\
\hline PENNY: Yep! & PENNY: ¡Sí! \\
\hline $\begin{array}{l}\text { SHELDON: Wait, no, no! No! The word } \\
\text { is "Polish." See, look. Polish sausage. } \\
\text { And the model of the solar system } \\
\text { developed by Nicolaus Copernicus, a } \\
\text { Polish astronomer. And then, finally, if } \\
\text { that wasn't enough --which it should've } \\
\text { been-- this is Madame Curie } \\
\text { killing herself by discovering radium, } \\
\text { who, although she was } \\
\text { a naturalized French citizen, } \\
\text { was Polish by birth! }\end{array}$ & $\begin{array}{l}\text { SHELDON: Espera, jno, no! ¡No! La } \\
\text { palabra es "Lacan". Ves, mira. LA tira } \\
\text { de CANtimpalos. Y el modelo del } \\
\text { sistema solar de Copérnico, cuya } \\
\text { revolución científica es comparable a la } \\
\text { de Lacan. Finalmente, si eso no fuera } \\
\text { suficiente, aunque debería haberlo sido, } \\
\text { esta es Madame Curie, una científica } \\
\text { de nacionalidad francesa, ipaís de } \\
\text { origen de Lacan! } \\
\text { PENNY: La palabra es "laca". ¿Ven? } \\
\text { Sin la "n". }\end{array}$ \\
\hline
\end{tabular}

Independientemente de los gustos y opiniones personales, es indiscutible que estas versiones al menos intentaron recuperar el núcleo central y el efecto del mensaje e hicieron un uso eficaz de la información ofrecida por el canal visual inalterable de las imágenes, adaptándola al propósito final.

\section{b. CUANDO LA IMAGEN TIENDE UN PUENTE}

Esta secuencia transcurre entre los minutos 2:03 y 2:49.

En esta escena, la confusión se suscita porque uno de los personajes principales de la serie, Howard Wolowitz, apodado Howie por su esposa Bernadette y quien acaba de aterrizar después de varios meses de una misión espacial, cree que la multitud de fotógrafos presente en el aeropuerto se ha reunido ahí por él, cuando en realidad están ahí para recibir a otro pasajero, Howie Mandel, un conocido animador y humorista estadounidense. Este problema podría catalogarse como de índole cultural, dado que, al momento de exhibirse esta temporada en Estados Unidos, Howie Mandel ya era una celebridad en ese país, 
mientras que en Latinoamérica su nombre no tenía mayor trascendencia o era desconocido. Por eso, el primer indicio que se le brinda al espectador a través del canal visual, el cartel en la mano del chofer, posiblemente haya pasado inadvertido para la mayoría del público latinoamericano (foto 5).

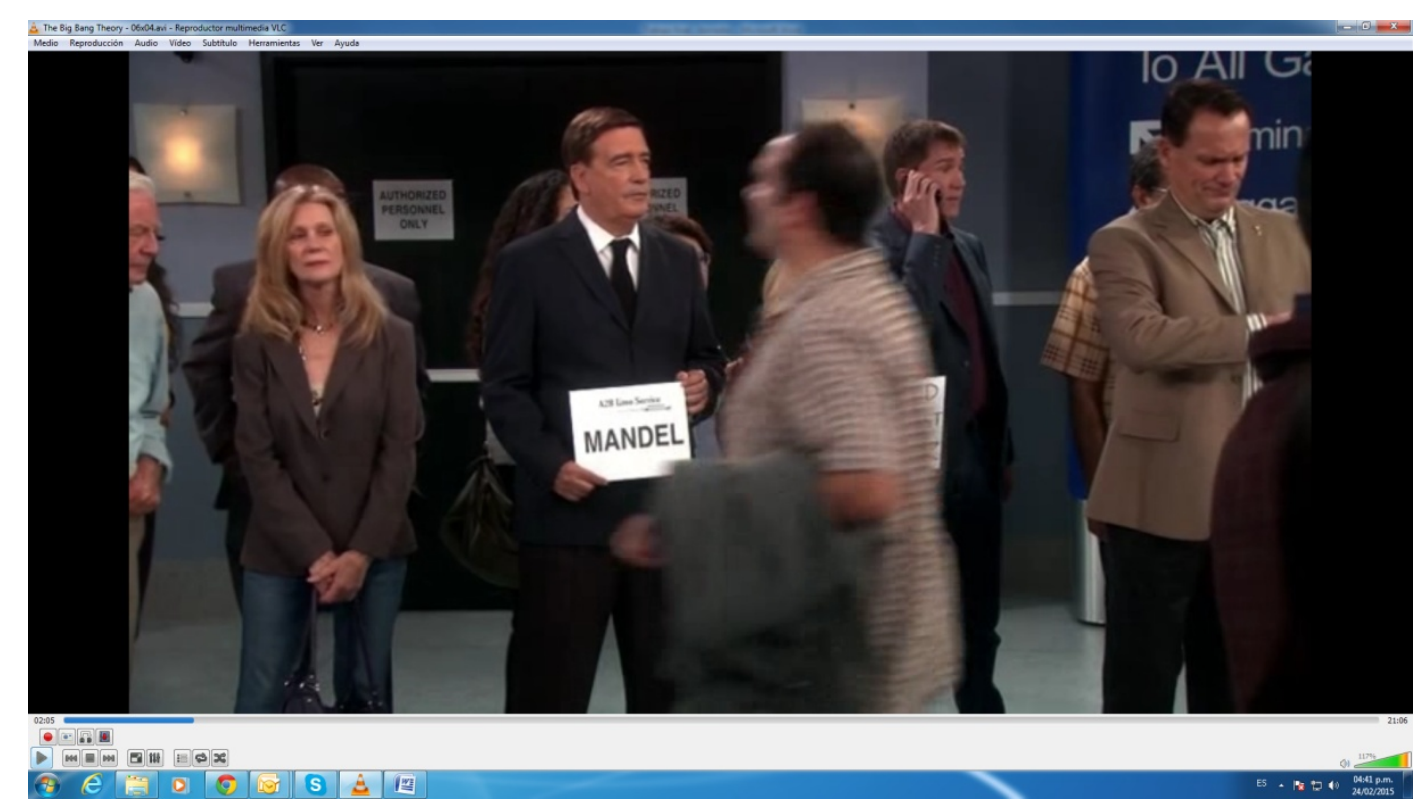

Foto 5

En este caso, los conocimientos previos y las conexiones autorreferenciales que pueda hacer el público varían con cada país y con cada grupo social y, por lo tanto, no siempre ayudan a que el espectador interprete la situación y responda al efecto del gag con la reacción esperada ${ }^{62}$. Sin embargo, la imagen en movimiento proporciona otro indicio, totalmente universal, que permite deducir, más allá de las fronteras y las pertenencias socioeconómicas, que el tal Howie Mandel es notablemente más famoso que el protagonista de la serie, Howard Wolowitz: en cuanto Mandel cruza la puerta, todos los fotógrafos se arremolinan frente a él (foto $6)$.

\footnotetext{
62 En el momento de la escritura de este trabajo (2014-2015), Howard Mandel era miembro del jurado del programa estadounidense "America's Got Talent", que se emite subtitulado y solamente por televisión por cable.
} 


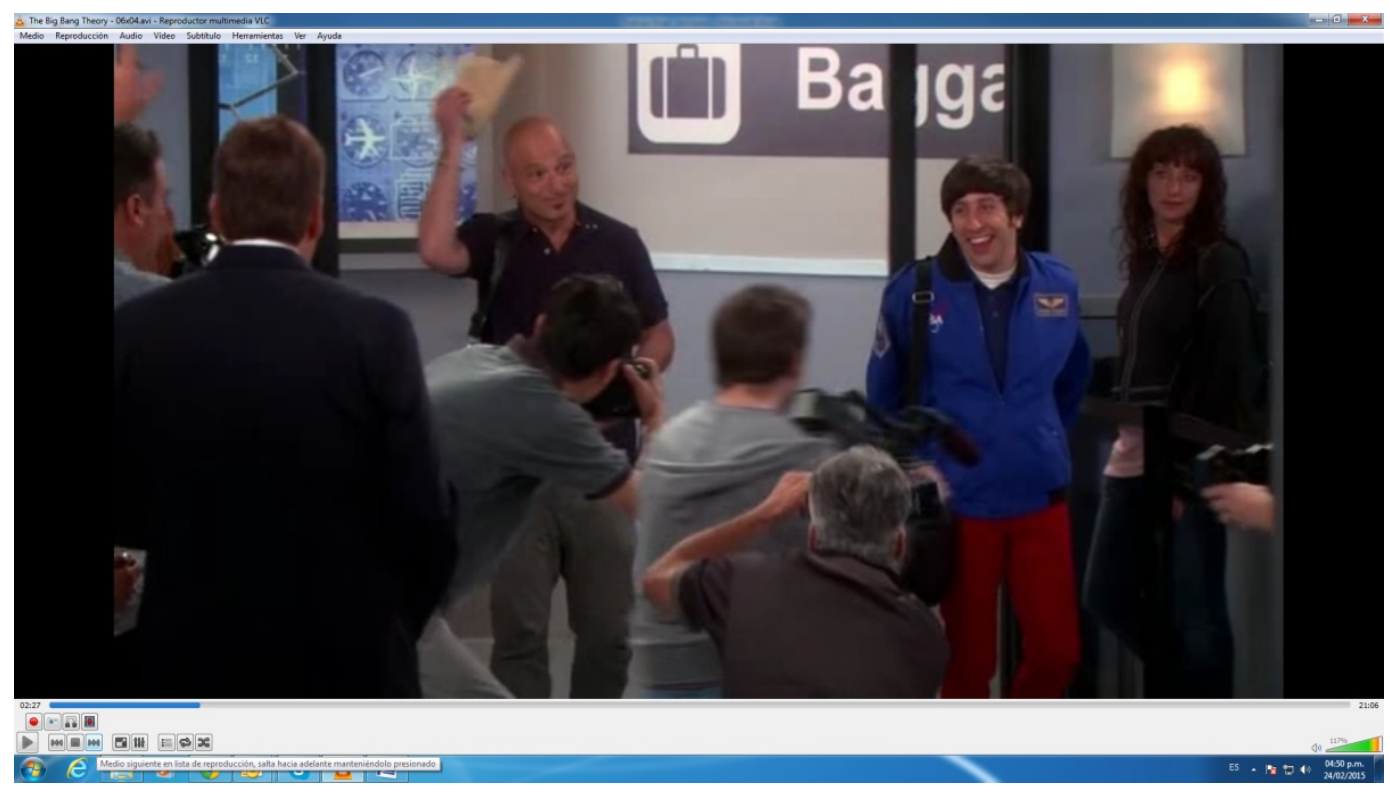

Foto 6

La confusión se refuerza cuando tanto Bernadette como los fotógrafos exclaman el mismo apodo, "Howie", casi simultáneamente en el momento en que ambos hombres aparecen en el hall del aeropuerto.

Esta escena demuestra de qué manera el sistema de la imagen en movimiento (el enjambre de fotógrafos que corre hacia Mandel), el sistema sonoro (Bernadette y los fotógrafos llaman a los dos por el mismo diminutivo) y la participación activa del espectador, que aplica, consciente o inconscientemente, sus saberes previos, colaboran con el sistema de la imagen fija (el subtítulo), lo que evita que se deba reformular el texto original como en el caso anterior con el objetivo de obtener el efecto deseado.

\begin{tabular}{|l|l|}
\hline TEXTO ORIGINAL & TEXTO TRADUCIDO \\
\hline $\begin{array}{l}\text { BERNADETTE: Waiting for my } \\
\text { husband. }\end{array}$ & $\begin{array}{l}\text { BERNADETTE: Estoy esperando a mi } \\
\text { esposo. } \\
\text { DRIVER: That's nice. }\end{array}$ \\
$\begin{array}{l}\text { CHOFER: Qué bien. } \\
\text { from outer space. }\end{array}$ & BERNADETTE: Viene del espacio. \\
$\begin{array}{l}\text { DRIVER: I think this flight's } \\
\text { coming from Houston. }\end{array}$ & $\begin{array}{l}\text { CHOFER: Creí que este vuelo venía de } \\
\text { Houston. }\end{array}$ \\
& BERNADETTE: Quise decir... No \\
\hline
\end{tabular}




\begin{tabular}{|l|l|}
\hline $\begin{array}{l}\text { BERNADETTE: No, I mean, he... } \\
\text { Never mind. }\end{array}$ & importa. \\
There he is! Howie! & ¡Ahí está! ¡Howie! \\
PHOTOGRAPHERS: Howie! & FOTÓGRAFOS: ¡Howie! \\
HOWARD W.: Whoa, thank you. & $\begin{array}{l}\text { HOWARD W.: Guau, gracias. Es } \\
\text { Great to be back on Earth. }\end{array}$ \\
$\begin{array}{l}\text { HOWARD M.: Uh, I think they're here } \\
\text { for me, Ringo. }\end{array}$ & HOWARD M.: Creo que vinieron por mí, \\
\end{tabular}

\section{c. CUANDO LA IMAGEN ES LA ÚNICA FUENTE DE INFORMACIÓN}

¿Qué ocurre cuando el significado se genera a través de un solo sistema y utiliza en el lenguaje de partida códigos inalterables e inexistentes en la lengua de llegada? ¿Qué ocurre cuando no es factible tomar elementos variados, tanto del canal visual como del sonoro, para que se complementen y adecuen al objetivo central de la traducción?

Tomemos un ejemplo de la serie de dibujos animados para niños "Los padrinos mágicos"; el episodio elegido es el quince de la tercera temporada, "Pipe Down". El protagonista, Timmy, cansado de que las personas a su alrededor le griten y se griten entre sí, formula un deseo a sus padrinos mágicos antes de irse a dormir: que reine en el mundo un silencio absoluto. Al día siguiente, desde el momento en que abre los ojos, advierte que su deseo se hizo realidad. Al principio, disfruta de la situación, pero cuando descubre que un meteorito está a punto de destruir la ciudad donde vive, entiende que él y sus vecinos necesitan hablar y ser escuchados para comunicar el peligro inminente. Ante la imposibilidad de emitir ninguna clase sonido, la única forma que Timmy encuentra para pedir a sus padrinos que anulen su deseo es inventando una especie de charada. La frase que Timmy pretende formar es I wish for sound (Deseo que haya sonido), y 
la situación humorística se centra en la torpeza de los padrinos mágicos, quienes confunden las palabras que Timmy quiere expresar por otras cuasi-homófonas.

La escena transcurre en un absoluto silencio, excepto por la música de fondo. Timmy se esfuerza por transmitir la primera palabra (fotos 7, 8, 9, 10 y 11).

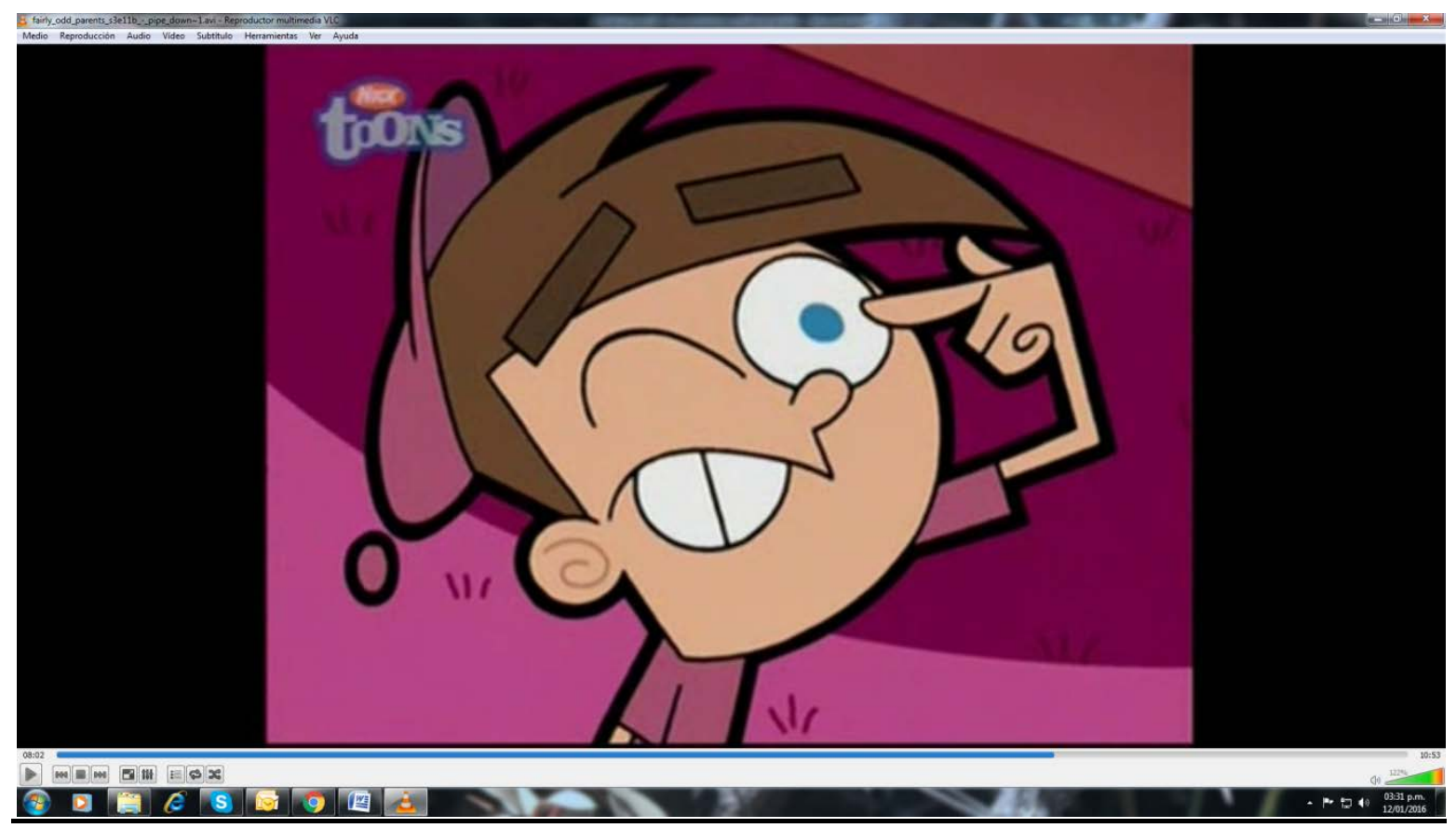

Foto 7 


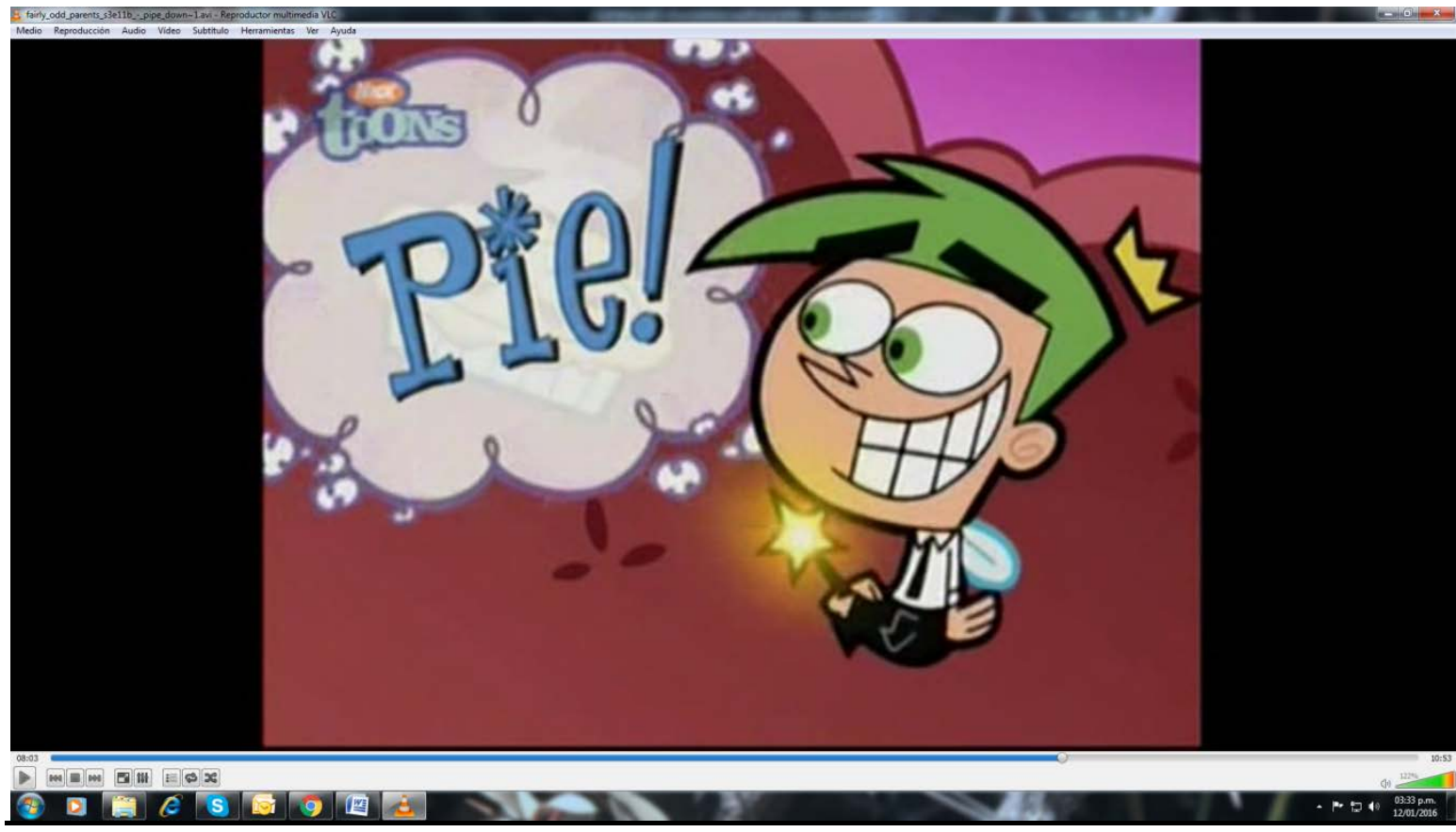

Foto 8

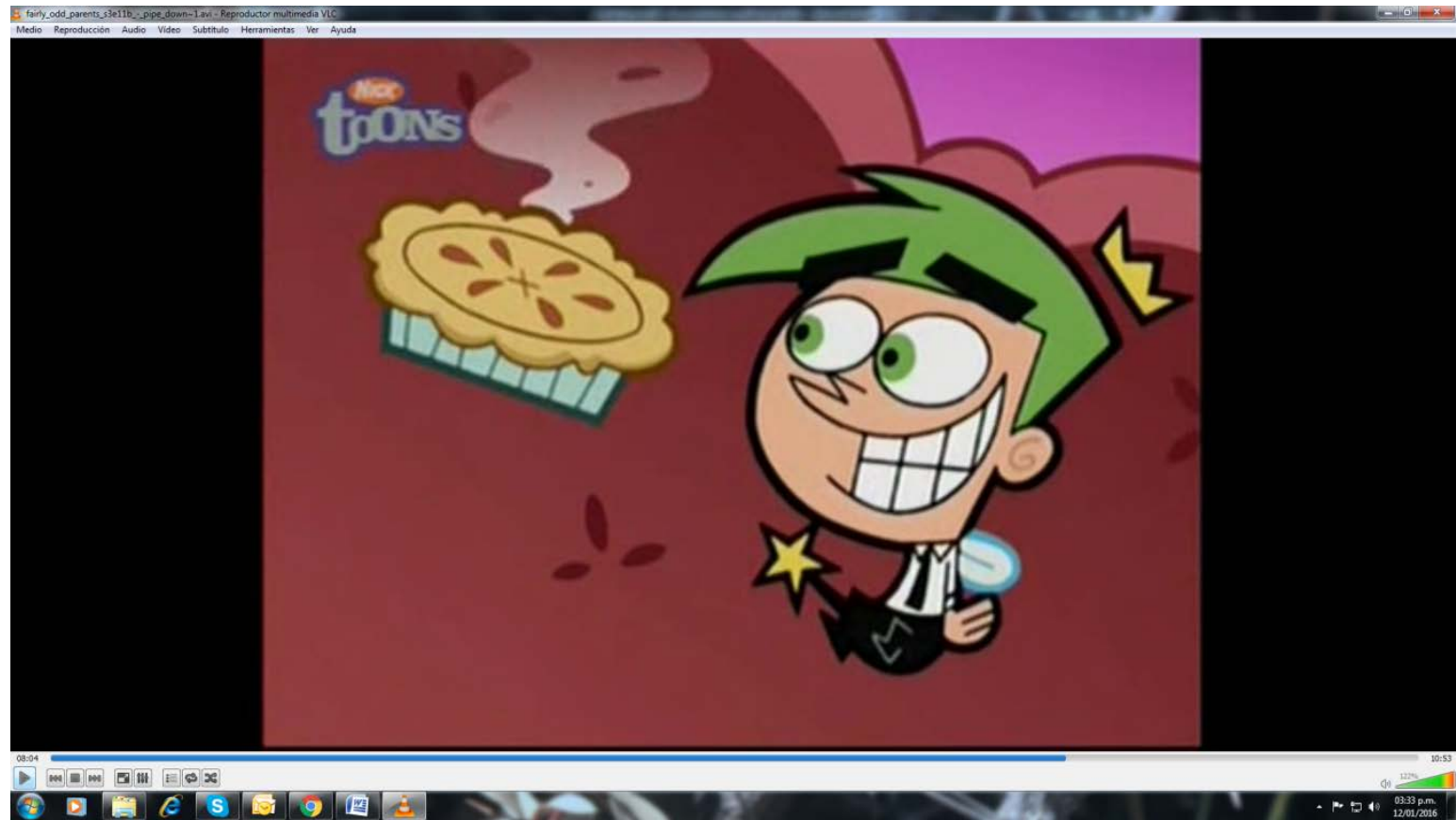

Foto 9 


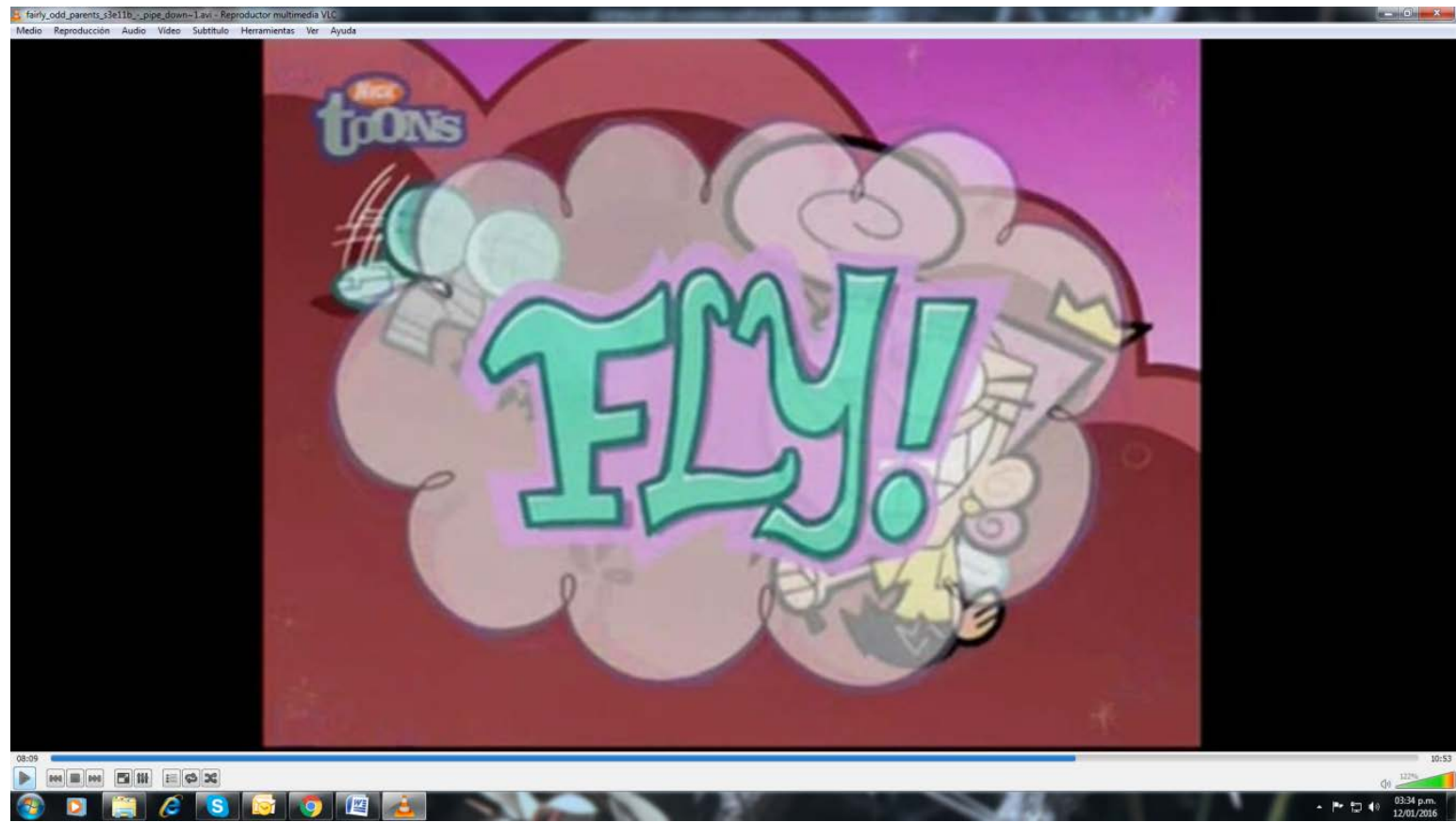

Foto 10

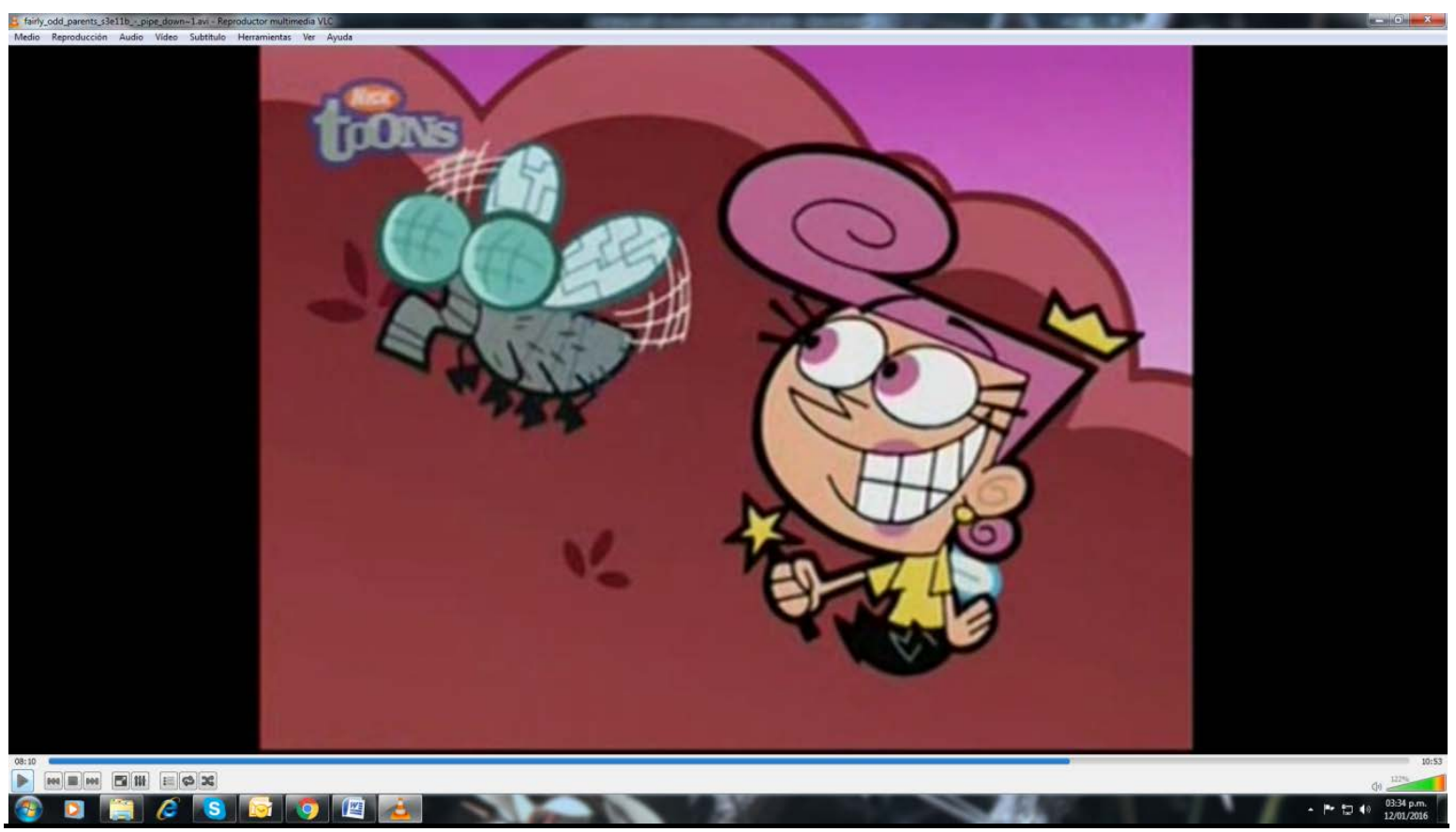

Foto 11 
La palabra eye (ojo) se pronuncia /ai/, sonido que rima con pie (pastel o tarta), /pai/, y con fly (mosca), /flai/, pero principalmente es homófona de I (yo), /ai/.

Cuando finalmente Wanda, la madrina mágica, logra desentrañar el enigma, Timmy emprende la dura tarea de transmitir la segunda palabra (fotos 12 y 13).

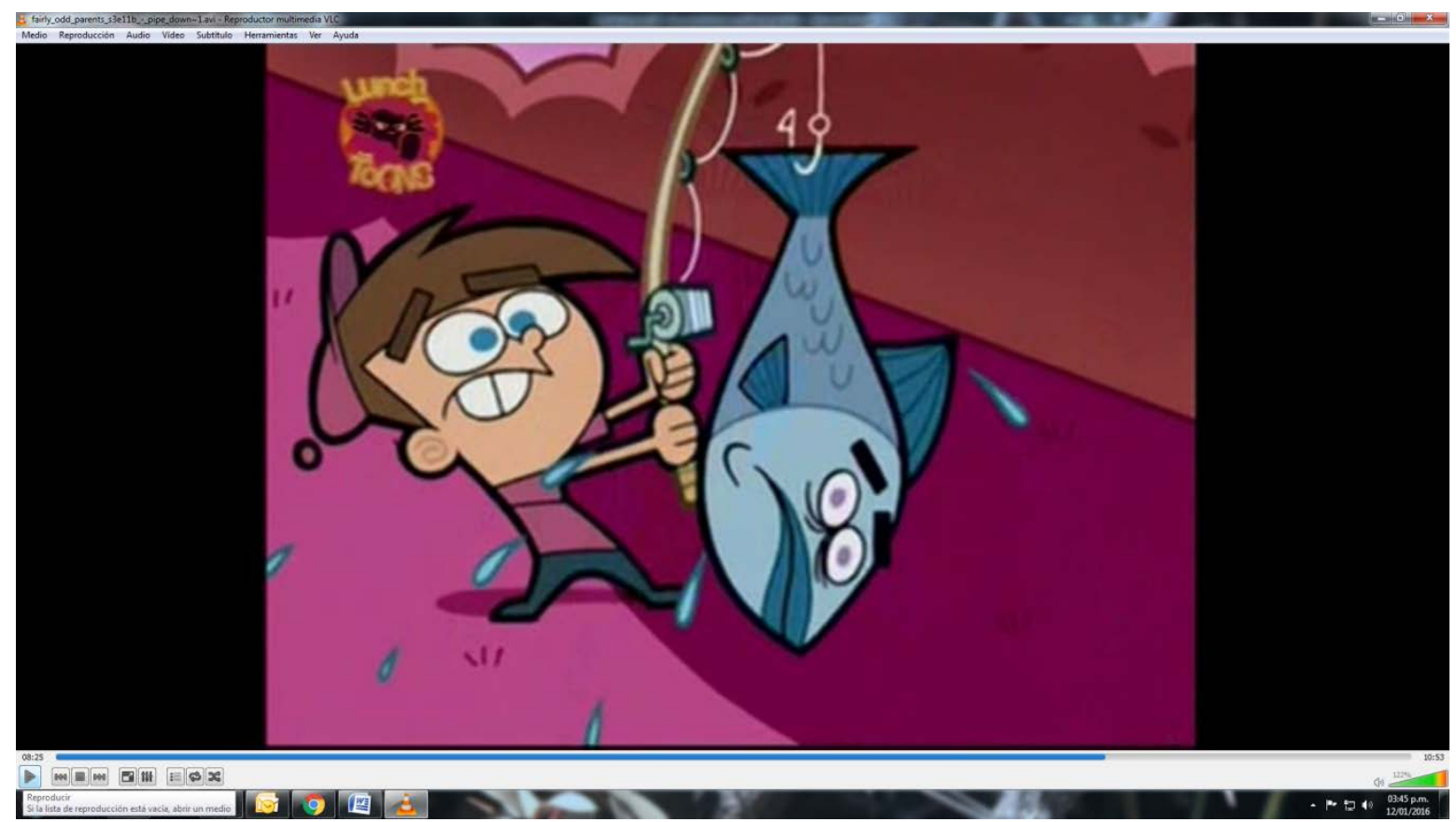

Foto 12

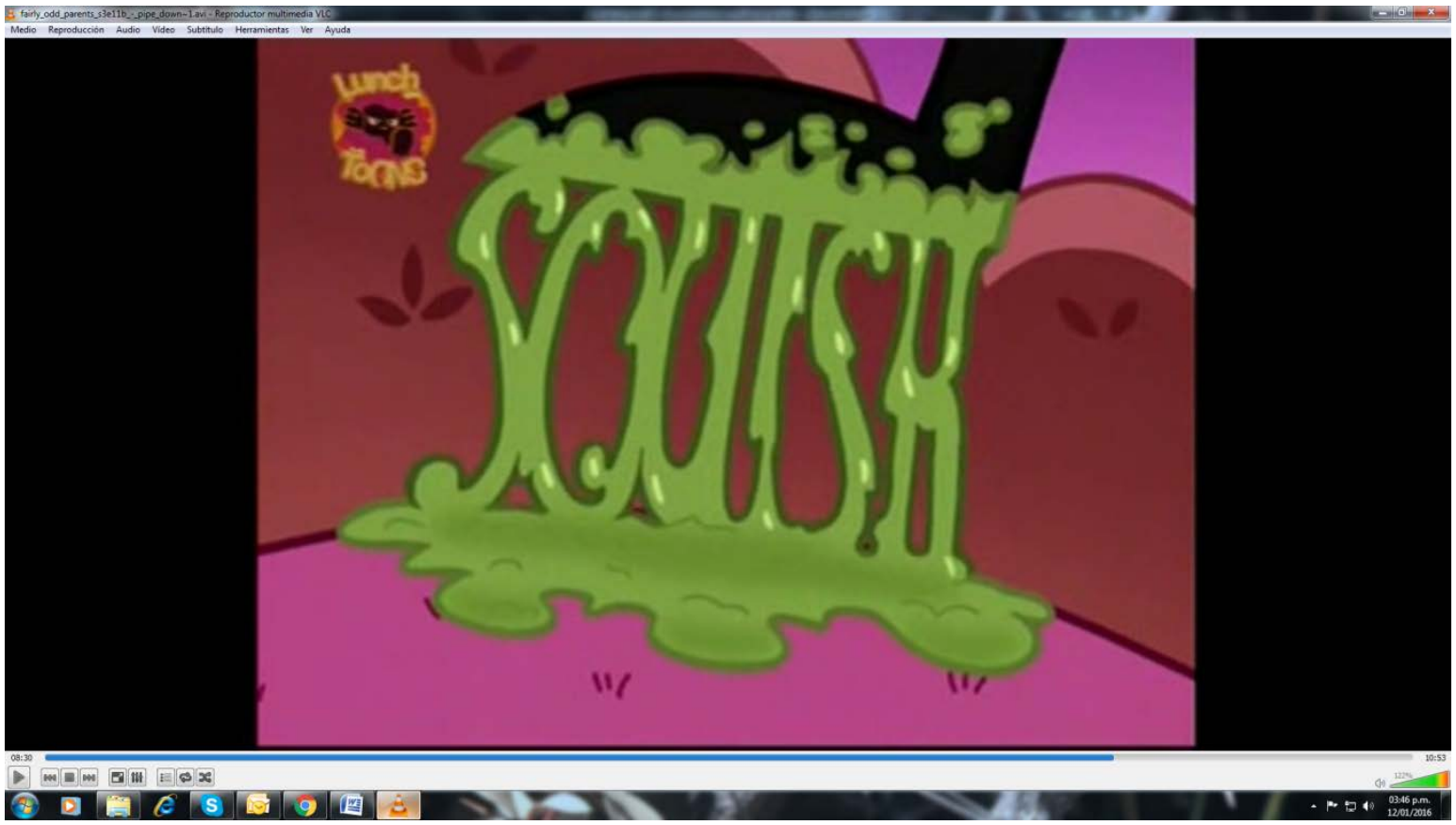


El término wish (deseo o desear) se pronuncia /uish/ y rima con fish (pez o pescado), /fish/, y con squish (aplastar), /scuish/ (Cosmo, el padrino mágico, primero crea un insecto y luego lo pisa con fuerza; al levantar el pie, se forma la palabra squish). Wanda asocia los sonidos con la función que cumple la varita mágica que Timmy señala desesperado y acierta nuevamente (foto 14).

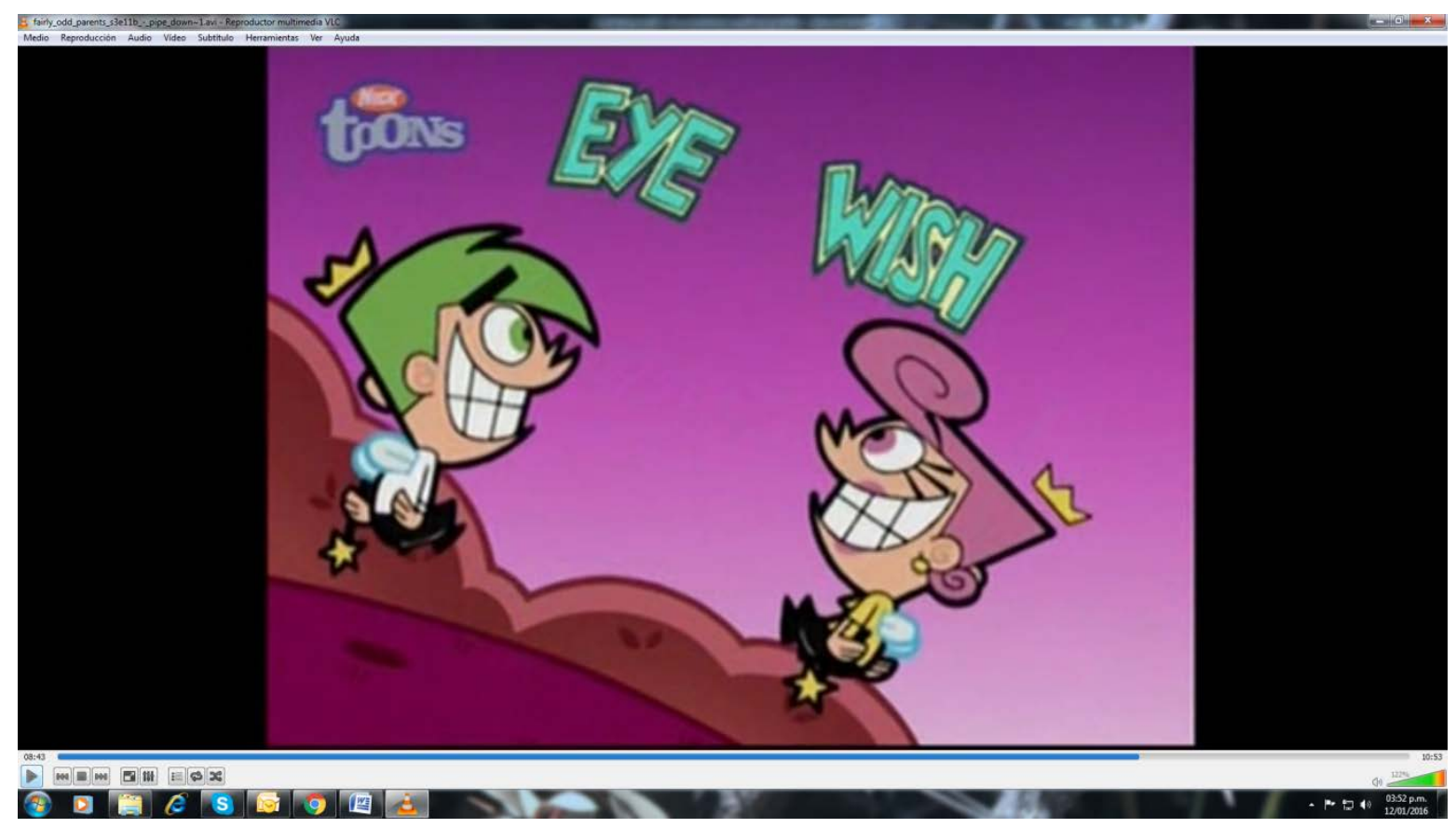

Foto 14

Cuando Timmy muestra cuatro de sus dedos, no pretende indicar que intentará transmitir la cuarta palabra de la frase, sino la tercera: for /for/ (preposición que, unida al verbo wish, indica 'desear algo'), homófona de four (cuatro), /for/ (fotos 15 y 16). 


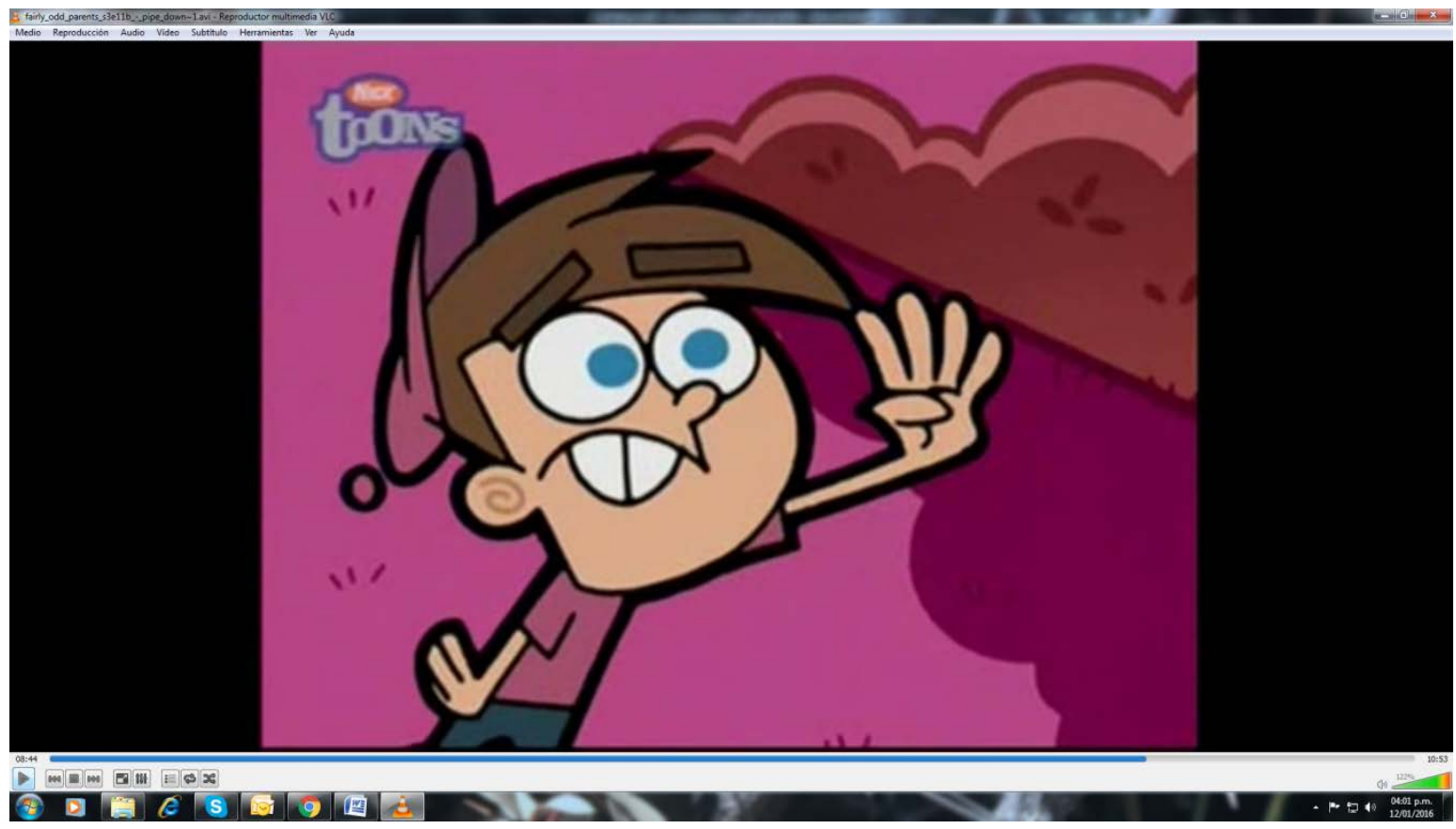

Foto 15

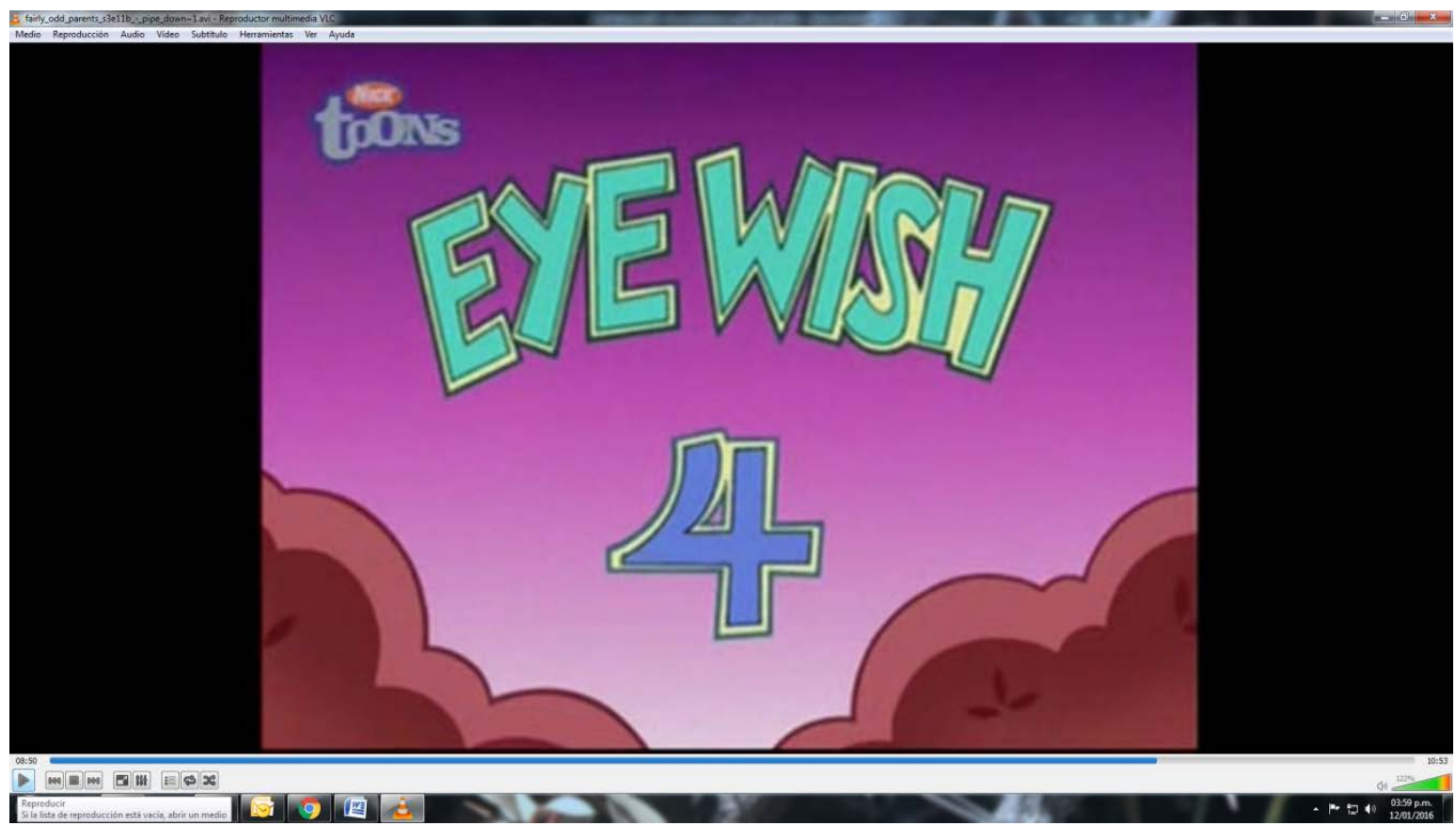

Foto 16

Por último, Timmy decide ofrecerle a Cosmo el taco que el padrino mágico había creado segundos antes para complacer el que suponía que era el deseo de Timmy (o el propio): comer algo rico. En su mente, Cosmo formula un agradecimiento. La palabra sound es polisémica en inglés y puede significar tanto 
'sonido' como, entre varias otras definiciones, ser un sinónimo informal de la expresión ‘¡Qué bueno! ${ }^{63}$ (fotos 17 y 18).

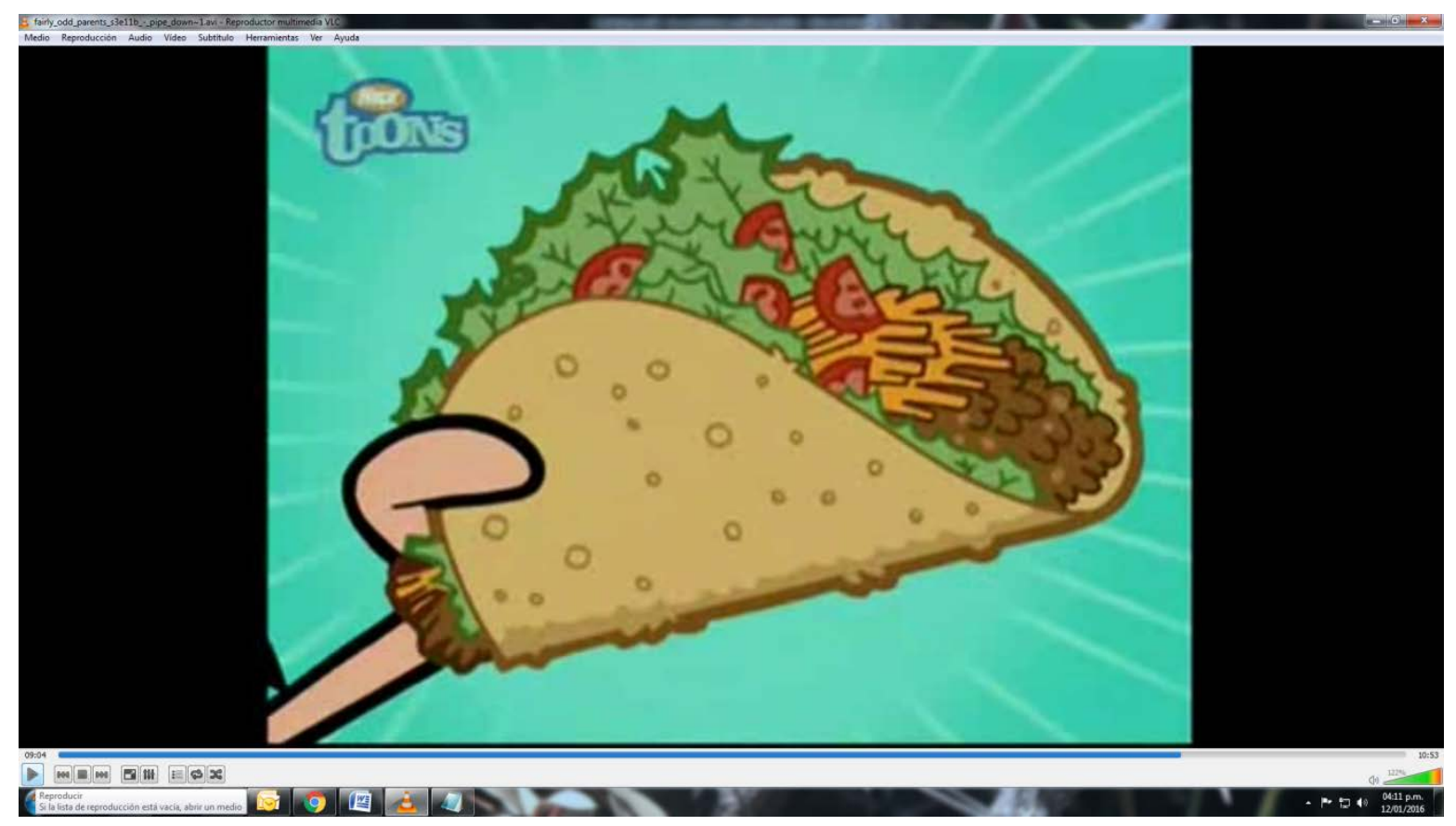

Foto 17

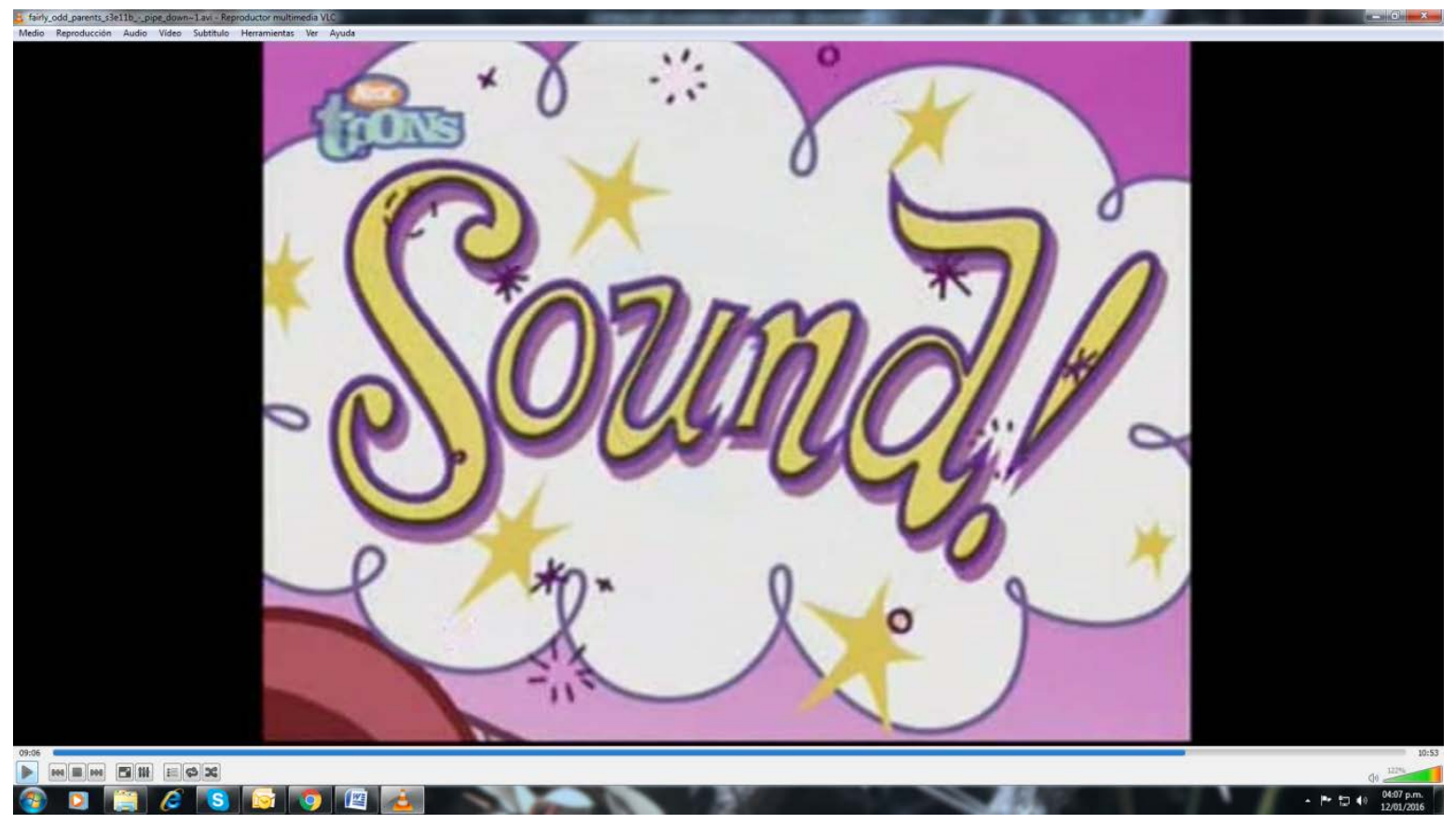

${ }^{63}$ http://www. urbandictionary. com/define.php?term=sound 
Así queda expresado el deseo de Timmy (foto 19).

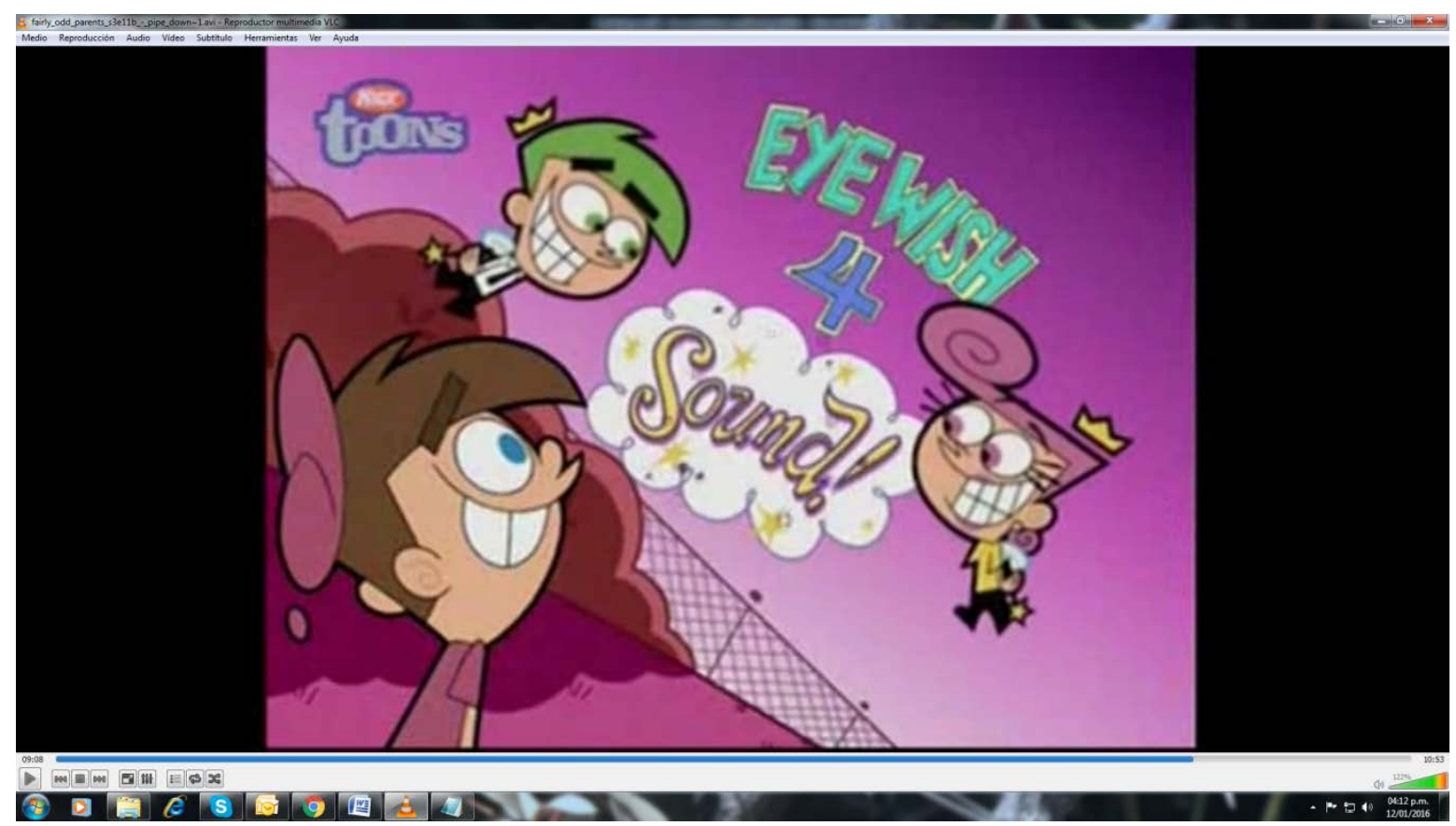

Foto 19

El sistema de imágenes estáticas y el conocimiento previo que el espectador angloparlante posee acerca de su propio idioma constituyen el único andamiaje sobre el que se sostiene la incongruencia que genera la situación humorística. El material destinado al público infantil se traduce casi en su totalidad en la modalidad de doblaje y se estila que, ante la presencia de textos en pantalla que no pertenecen al diálogo de los personajes, un narrador extradiegético los lea. Esto plantearía un primer problema en la traducción de la escena analizada: aunque el traductor intentara resolver los juegos de palabras con combinaciones factibles en castellano y los incluyera en el guión del narrador, no es posible comparar el impacto que tienen las palabras escritas o dibujadas en la pantalla con las que pudiera enunciar en forma oral un agente externo a la acción. Encarar la traducción de un texto de estas características exige explorar al máximo los límites de la lengua castellana y no se debería descartar la idea de evaluar las posibilidades técnicas y legales de intervenir el material fílmico original insertando 
nuevos carteles, o incluso nuevos dibujos. No obstante, en este último caso, se trataría de una adaptación y no de una traducción.

Como se expresó a lo largo de todo el trabajo, la traducción de textos audiovisuales, por la permanencia efímera de la imagen visual verbal en la pantalla, requiere de suma claridad y eficacia. Por lo tanto, frente a estos desafíos extremos, habría que plantearse la conveniencia de traducir el material para ser emitido comercialmente.

\section{CONCLUSIONES}

En primer lugar, es pertinente reiterar que la intención de este trabajo no es corroborar ni refutar una hipótesis inicial, sino reflexionar sobre el proceso intuitivo e inconsciente que se produce en el traductor de subtítulos cuando se ve obligado a tomar la decisión de recortar u omitir información. Por lo tanto, y de acuerdo con la definición que propone Eco, se trataría de un trabajo monográfico, centrado en un objeto -el subtítulo-, al que se lo analiza en sus aspectos concretos -el subtítulo como elemento visual- y en sus aspectos abstractos -el texto que lo conforma y sus distintas posibilidades interpretativas-. El objetivo central es repensar las prácticas del oficio a partir de enfoques teóricos relacionados con la imagen y la comunicación visual, en la pretensión de que los traductores sistematicen ( $y$, en consecuencia, optimicen) su método de trabajo.

Por su función comunicativa emotiva y estética, como ocurre con toda creación artística, los textos audiovisuales son irrepetibles e imprevisibles. Esta particularidad queda demostrada en el análisis de los casos reales, en los que el aporte del canal visual verbal y no verbal propone distintos grados de limitación a la traducción del texto original. (Se presentaron casos de equivalencias transparentes, de colaboración, de limitación parcial y de limitación total). Primera conclusión: la aplicación de un único procedimiento para el recorte, omisión o adaptación de material audiovisual resulta utópico e improcedente. 
La segunda conclusión es que el subtítulo es una convención gráfica y hay que analizarlo como una de las tantas imágenes que conforman el texto audiovisual. Conceptos pictóricos relacionados con el trazo de las perspectivas, la ubicación de los elementos dentro de un encuadre (en este caso, el de la pantalla) y el posicionamiento natural del espectador frente a la obra explican las razones por las que el subtítulo debe ocupar, en condiciones ordinarias, un lugar fijo y establecido. Asimismo, se indica que la conveniencia de mantener esta convención está respaldada por las propuestas de estandarización para la traducción en formato de subtitulado en Europa.

La tercera conclusión -este ordenamiento no expresa de ninguna manera el grado de importancia de las conclusiones- está vinculada a la anterior y es que, en la elaboración de subtítulos, la información debe transmitirse de modo claro, preciso y eficaz. Para alcanzar este postulado, es necesario, en ocasiones, "podar" el texto original de los elementos de orden secundario y permitir que los datos esenciales se resalten. El enfoque multimodal pone de manifiesto los aportes que los distintos elementos, tanto textuales como no textuales, hacen a la diégesis audiovisual y cómo se complementan; además, al estar inserto dentro de la semiótica social, no descarta el papel que juegan el contexto y los saberes previos del traductor y del espectador en la cadena interpretativa y nos advierte acerca de la inevitable presencia de distintas miradas sobre el texto de origen, todas subjetivas. Esta advertencia no disciplina ni ordena la lectura que cada individuo realice de los valores connotativos presentes en el texto audiovisual, pero ayuda a que el traductor, como primer receptor y agente externo al proceso de comunicación ${ }^{64}$, tome consciencia de ello. Por otro lado, la teoría de la relevancia fomenta la reducción u omisión, e incluso la adaptación, de ciertos elementos del texto original al insistir en que la transmisión de cualquier clase de información debe generar expectativas de relevancia en el receptor con el fin de minimizar el esfuerzo en el proceso de asimilación del mensaje. Uno de los

\footnotetext{
${ }^{64}$ En general, los procesos de transmisión y recepción de información se piensan en términos intralingüísticos y no interlingüísticos.
} 
factores que simplifica y agiliza este procesamiento mental es que los receptores sepan de antemano el lugar en la pantalla donde aparecerá el texto.

Cuarta conclusión: por lo explicitado en el párrafo anterior, queda demostrado que el latiguillo de que "toda traducción implica una pérdida" es en parte falaz, ya que la relación entre los diferentes canales semióticos presentes en los textos audiovisuales es colaborativa: se complementan, se apoyan uno en el otro, y todos aportan significado a través de elementos que le son inherentes. Por consiguiente, el supuesto recorte de información que trae aparejada la modalidad de traducción en formato de subtitulado pasa a convertirse prácticamente en un mito.

Por último, no se descarta la ilusión de que este trabajo estimule la reflexión sobre las prácticas profesionales y promueva otros que permitan perfeccionar la tarea del traductor y mejorar las experiencias áulicas. 


\section{BIBLIOGRAFÍA}

$\checkmark$ Agost, Rosa y Chaume, Frederic (eds.). (2001). "La pretendida oralidad de los textos audiovisuales y sus implicaciones en la traducción". En La traducción en los medios audiovisuales (77-88). Barcelona: Universitat Jaume I.

$\checkmark$ Arnheim, Rudolf. (1984). El poder del centro. Madrid, España: Alianza.

$\checkmark$ Aumont, Jacques. (1992). La imagen. Barcelona, España: Paidós.

$\checkmark$ Barthes, Roland. (1964). "Retórica de la imagen". En La semiología (127-140).

$\checkmark$ Berg, W. B. (2002). "Literatura y cine. Nuevos enfoques del concepto de intermedialidad". Iberoamericana, II, 127-141.

$\checkmark$ Bogucki , Łukasz. (2004). "The Constraint of Relevance in Subtitling". Journal of Specialised Translation Issue 01. University of Lodz. www.jostrans.org/issue01/art_bogucki_en.pdf

$\checkmark$ Díaz Cintas, Jorge. (2003). Teoría y práctica de la subtitulación inglés/español. Barcelona, España: Ariel.

$\checkmark$ Eco, Umberto. (2000). Tratado de semiótica general. Barcelona, España: Lumen.

$\checkmark$ Escandell Vidal, María Victoria. (2000). "Sintaxis y uso interpretativo". En Palabras: Víctor Sánchez de Zavala in memoriam. Bilbao, España: Servicio de publicaciones de la Universidad del País Vasco.

$\checkmark$ Genette, Gerard. (1989). Palimpsestos. La literatura en segundo grado. Madrid, España: Taurus Alfaguara.

$\checkmark$ Jay, Martin. (2007). Ojos abatidos - La denigración de la visión en el pensamiento francés del siglo XX. Madrid, España: Akal. 2007 
$\checkmark$ Kress, Gunther. (2012). Multimodality. A Social Semiotic Approach to Contemporary Communication. Nueva York, Estados Unidos: Routledge.

$\checkmark$ Karamitroglou, Fotios. (1998). "A Proposed Set of Subtitling Standards in Europe". Translation Journal, Vol. 2 Número 2, abril.

$\checkmark$ Kress, Gunther. (2004). Reading Images: Multimodality, Representation and New Media. Expert Forum for Knowledge Presentation; Conference: Preparing for the Future of Knowledge Presentation).

http://www.knowledgepresentation.org/BuildingTheFuture/Kress2/Kress2. html. 2004

$\checkmark$ Leonetti, Manuel. (2006). "Gramática y pragmática". Trabajo enmarcado dentro de la investigación correspondiente al proyecto "Semántica procedimental y contenido explícito". Universidad de Alcalá.

$\checkmark$ Machado, Arlindo. (2000). El paisaje mediático - Sobre el desafío de las poéticas tecnológicas. Buenos Aires, Argentina: Libros del Rojas.

$\checkmark$ Machado, Arlindo. (2009). "Todos los films son extranjeros". En Extranjeros en la tecnología y en la cultura (111-122). Barcelona, España: Ariel.

$\checkmark$ Marafioti, Roberto (comp.). (2001). Recorridos semiológicos: signos, enunciación y argumentación. Buenos Aires, Argentina: Eudeba.

$\checkmark \quad$ Martí Ferriol, José Luis. (2013). "Subtitle reading speeds in different languages: the case of Lethal Weapon ". Quaderns, Revista de Traducció, Número 20, 201-210.

$\checkmark$ Metz, Christian. (2002). Ensayos sobre la significación en el cine (1964-1968). Volumen I. Paidós

$\checkmark$ Mitchell, William J. (1994) Picture Theory. Estados Unidos: The University of Chicago.

$\checkmark$ Skuggevik, Erik. (2009). "Teaching Screen Translation: The Role of Pragmatics in Subtitling". En Audiovisual Translation: Language 
Transfer on Screen (Jorge Díaz Cintas y Gunilla Anderman (eds.) (197 a 213). Inglaterra: Palgrave, MacMillan.

$\checkmark$ Sperber, D. y Wilson, D. (1994). Outline of Relevance Theory. Links \& Letters 1. Universitat Autònoma de Barcelona.

$\checkmark$ Sperber, D. y Wilson, D. (2004). "La teoría de la relevancia". Revista de Investigación Lingüística. Vol. VII.

$\checkmark$ Stahl, Anna-Kazumi. (2012). "Lecturas posibles del japonés". En La traducción literaria en América Latina - Gabriela Adamo (comp.) (177-192). Argentina: Paidós; Fundación TyPA

$\checkmark \quad$ Swayles, John M. (1990). Genre Analysis: English in Academic and Research Settings. Nueva York, Estados Unidos: Cambridge University Press.

$\checkmark$ Valsiner, Jaan y Han, Gyuseog. (2008). "Where Is Culture Within The Dialogical Perspectives of The Self?". International Journal for Dialogical Science. Volume 3 número 1 fall (1-8)

$\checkmark$ Verón, Eliseo. (1993). La semiosis social, fragmentos de una teoría de la discursividad. Barcelona, España: Gedisa, Colección El mamífero parlante. 